\title{
Price Controls and International Petroleum Product Prices
}

February 1980

Prepared for:

U.S. Department of Energy

Energy Information Administration

Assistant Administrator for Applied Analysis

Under Contract No. P-03-77-6039-0 


\section{DISCLAIMER}

This report was prepared as an account of work sponsored by an agency of the United States Government. Neither the United States Government nor any agency Thereof, nor any of their employees, makes any warranty, express or implied, or assumes any legal liability or responsibility for the accuracy, completeness, or usefulness of any information, apparatus, product, or process disclosed, or represents that its use would not infringe privately owned rights. Reference herein to any specific commercial product, process, or service by trade name, trademark, manufacturer, or otherwise does not necessarily constitute or imply its endorsement, recommendation, or favoring by the United States Government or any agency thereof. The views and opinions of authors expressed herein do not necessarily state or reflect those of the United States Government or any agency thereof. 


\section{DISCLAIMER}

Portions of this document may be illegible in electronic image products. Images are produced from the best available original document. 


\section{Price Controls and International Petroleum Product Prices}

February 1980

Prepared by:

Robert T. Deacon

Walter J. Mead

Vinod B. Agarwal

Community and Organization Research Institute

University of California

Santa Barbara, California

ThiscLAIMER

This book was prepared as an account of work sponsoree by an agener of the United States Governmen. Neither the United States Government nor any agency thereot, nor ony of their employees, makes any warraniy, express or implied, or assumes any lagal liabilitey or responsibility tor the accurecy.

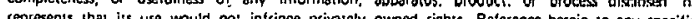

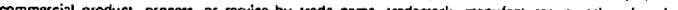

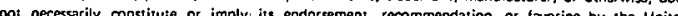

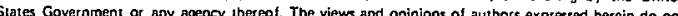

necessarily state or reflect those of the United States Government or any agency thereaf.

Prepared for:

U.S. Department of Energy

Energy Information Administration

Assistant Administrator for Applied Analysis

Office of Economic Analysis

Regulatory and Competitive Analysis Division

Washington, D.C.

Under Contract No. P-03-77-6039-0 
This report examines the effect of U.S. price control policy on the price of motor gasoline through 1977. The empirical. analysis is achieved primarily by comparing (domestic and foreign gasoline prices. The study undertakes two sorts of comparisons, one of which is based on the prices of products actually moving in international trade, while the other tries to ascribe U.S. foreign market price differentials to identifiable cost factors. Primary emphasis is on price comparisons at the wholesale level, although some retail comparisons are presented. THe study also examines the extent to which product price controls are binding. The time period under consideration is from 1969 through 1977, with primary focus on price relationships in 1970-1971 (just before U.S. controls) and 1976-1977. The forelgn-domestic comparisons are made with respect to four major U.S. cities, namely, Boston, New York, New Orleans, and Los Angeles.

This report was prepared under Department of Energy (DOE) Contract Number p-03-77-6039-0 and does not necessarily state or reflect the views, opinions, or policies of the DUE or the Federal Government References to trade names or specific commercial products, commodities, or services in this report do not represent or constitute an endorsement; recommendation, or favoring by DOE of the specific commercial product, commodity, or service. 


\section{$\underline{\text { PREFACE }}$}

This paper was prepared as the final report under contract \#P-.03-77-6039-0, issued by the Federal Energy Administration. The contractor was the Community and Organizational Research Institute of the University of California (Santa Barbara). The purpose of the study was to examine/the effects of Federal refined product price controls upon the price of motor gasoline in the United States. This was accomplished by examining the bindingness of the product price controls, and by attempting to estimate what the price of motor gasoline would have been absent in the controls.

The project was completed under the general supervision of David L. Shapiro and W. David Montgomery III. The Technical Project Officer was David Mead. Walter J. Mead of UCSB was the Principal Investigator, while Robert T. Deacon served as Co-Principal Investigator. 
TABLE OF CONTENTS

Page

SUMMARY AND CONCLUSIONS . . . . . . . . . . . . . . . . . . i

Chapter 1: HISTORY OF PRICE CONTROLS . . . . . . . . . . . . . 1

1.1: The Current Regulations .............. 2

1.2: Regulations During Phase IV and After ........ 5

Chapter 2: A REVIEW OF THE LITERATURE ON PRICE CONTROLS IN

DOMESTIC ENERGY MARKETS . . . . . . . . . . . . 14

2.1: Summary of Major Findings of Past Studies . . . . . 14

2.2: The Effects of Controls on Crude $0 i 1$ Markets . . . . 16

2.3: Refined Products Markets ............ 19

2.4: Concluding Comments ............ . 37

Chapter 3: THE EFFECTS OF PRICE REGULATIONS ON REFINERS . . . . . 39

3.1: U.S. Refined Product Markets: 1974 ........ 39

3.2: Regulation of the Refining Industry After 1974 . . . 51

3.3: Price Controls in Retail Markets . . . . . . . 58

3.4: Empirical Evidence ............. 60

Chapter 4: FOREIGN-DOMESTIC GASOLINE PRICE COMPARISONS BASED UPON PRODUCTS MOVING IN TRADE ............ 68

4.1: International Trade and Foreign-Domestic Price Relationships................ 68

4.2: Foreign Trade and Price Controls . . . . . . . 78

4.3: Data Used in Empirical Study of Wholesale Prices . . 83

4.4: Analysis of Variance on Foreign and Domestic Gasoline Prices................ 91

4.5: The Monthly Pattern of Foreign and Domestic Gasol ine Prices .................. 103

4.6: Conclusions .................. 109 
Chapter 5: FOREIGN-DOMESTIC GASOLINE PRICE COMPARISONS BASED UPON COST FACTORS . . . . . . . . . . . . 111

5.1: The Basis for Price Comparisons ......... . 111

5.2: The Choice of a Comparison Country . . . . . 114

5.3: Data and Methodology Used in Wholesale Price Comparisons ................ 118

5.4: Empirical Results on Wholesale Gasoline Prices . . 127

5.5: Some Tentative Retail Price Comparisons ...... . 137

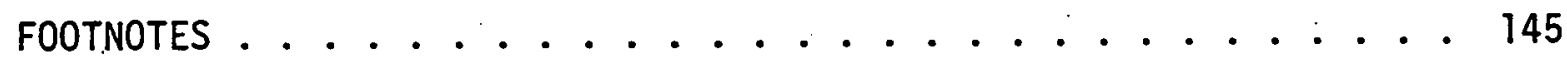

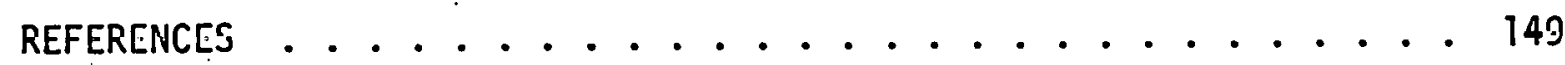

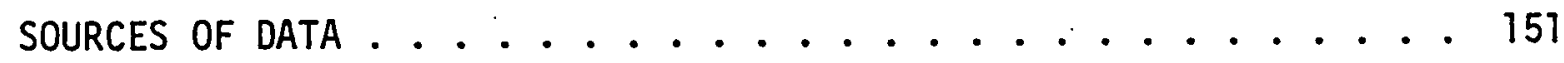




\section{SUMMARY AND CONCLUSIONS.}

The purpose of the analysis contained in this document is to examine the influence of U.S. price control pricy: upon the price of motor gasoline. The primary vehicle for empirical analysis is comparison of domestic and foreign gasoline prices. Two sorts of comparisons were undertaken; the first is based upon prices. of products actually moving in international trade, while the second attempts to trace U.S. - foreign market price differentials to identifiable cost factors. Primary emphasis is placed upon price comparisons at the wholesale (ex refinery) level, although some retail comparisons are presented. This direction of emphasis was largely dictated by availability of data and the prevalence of foreign retail price regulations. The time period considered extends from 1969 through 1977, although primary attention is given to price relationships in 1970-71 (immediately prior to U.S. controls) and 1976-77. All foreign-domestic comparisons are made with respect to four major U.S. cities. The full report is partitioned into five chapters, and the analysis and results presented in each are summarized below.

Chapter 1 traces the development of price regulations on U.S. refined products from the institution of general price controls in August 1971 , through the implementation of specific petroleum industry controls in early 1973 and up to the present. The major policy changes surveyed are the Emergency Petroleum Allocation Act (EPAA), the Entitlements Program, and the Energy Policy and Conservation ACt (EPCA). As of this writing (June 1978), the Department of Energy has recorimended exemption of motor gasoline from federal controls. This development is not presented in the survey. 
The existing economic literature on U.S. petroleum price controls and their effects on energy markets is reviewed in Chapter 2. The discussion is focussed upon three detailed theoretical and empirical studies. Most previous authors have taken the absence of queues at service stations and the presence of positive banked costs (allowed price increases that have not been exploited by refined product suppliers) as casual evidence that price controls on motor gasoline and other products have not constrained the pricing decisions of petroleum product suppliers, at least since mid 1973. However, certain areas of disagreement remain, particularly regarding the effect of the Entitlements Program upon U.S. refined products prices. Some argue that the Entitlements Program, with its implicit subsidy on crude oil imports, is effectively depressing U.S. prices of motor gasoline and other products. Others argue that the presence of motor gasoline and other product imports into the U.S. demonstrates that domestic prices are effectively set on world markets, and that the Entitlements Program (and other price regulation policies) merely alter the magnitude of trade flows.

Chapter 3 develops an analytical model for assessing the impact of the major features of U.S. price controls upon petroleum product producers. Although this analysis was not specified in the program of research, it was deemed important since the analysis of other authors appeared flawed or incomplete in important respects. The major point of departure from earlier studies is in the disaggregation of analys is from the industry to the level of the individual firm. The primary conclusion reached is that price ceiling schedules may have varied substantially across various firms. Al though these differences would 
be expected to have been most dramatic prior to enactment of the Entitlements Program, some variation may have remained in later periods due, primarily, to such price control features as the "small refiners bias," the use of base period prices in computing ceiling prices, and certain features in the Entitlements Program under EPCA. Given such differences in price control schedules, it is shown that controls could have reduced domestic prices (essentially shifted the domestic supply schedule to the right over some ranges) and avoided queues. A major implication of binding controls on some firms is the presence of dispersion in refined product price quotations. Evidence that such dispersion was significant, at least until early 1975; is presented. Following implementation of the Entitlements Program, the degree of price dispersion was significantly reduced in all areas studied.

Chapter 4 presents a comparative analys is of U.S. prices of motor gasoline and landed prices of imports from major foreign supply sources. The purposes of these comparisons are: (i) to shed light upon the proposition that the presence of foreign gasoline imports implies that domestic price controls are ineffective, and (ii) to examine the foreign supply response likely to follow U.S. decontrol. Since foreign trade patterns are responsive to governmental trade restrictions, and since significant changes in U.S. import policy have occurred over the last decade, it was necessary to construct a simple model of the joint influences of trade restrictions and price controls on foreign-domestic price relationships. This model was used to formulate a variety of hypotheses that were then subjected to empirical scrutiny. It was found that during the perfod between relaxation of import quotas (in early 1973) and mid 1976, delivered prices of foreign gasol ine were significantly higher than domestic supply prices for virtually all of 
the comparisons examined. During this period, then, domestic gasoline prices (at wholesale) were not constrained by prices in world trade markets. Further, imports were regularly observed throughout this period. The only obvious explanation for this phenomenon is that price controls were effective for some domestic firms, and that high priced foreign gasol ine was imported only because these costs were allowed to pass through to ceiling prices. Since mid 1976, there has been a marked trend toward equality between domestic supply prices and landed prices of foreign imports in three of the four U.S. cities examined. As of 1977, the hypothesis that the domestic wholesale price of gasoline is equal to the delivered cost of (the least expensive) foreign imports cannot be refuted. This finding is consistent with the proposition that foreign imports are, at least partially, constraining U.S. prices and that competition from imports could be expected to mitigate any domestic price increases following decontrol.

Foreign-domestic price comparisons based upon differences in identifiable cost factors between U.S. and foreign gasoline markets are presented in Chapter 5. In effect, historic price increases (since 1970) in an unconstrained foreign market are used as a model for what would have occurred in the U.S. in the absence of price controls. In conducting these comparisons, allowances are made for differences in input costs, taxes and other factors which would induce price differences in the absence of controls. Empirical work is focussed primarily upon foreign and domestic wholesale price series, primarily because of data limitations and the prevalence of foreign controls on retail prices. Wholesale price comparisons indicate that U.S. price increases in three of the four cities examined between 1970-71 and 1976-77 have not 
differed significantly from price increases experienced in the Netherlands. Moreover, as of 1977, cost adjusted wholesale prices in the U.S. were not significantly lower than foreign wholesale prices in any of the U.S. cities examined. Rather, prices in two of the four U.S. cities actually exceeded prices in the Netherlands by a significant amount. Thus, the hypothesis that wholesale gasoline price increases in the U.S. have been at least as great as those experienced in the uncontrolled market, cannot be refuted. The final section of Chapter 5 presents evidence on motor gasoline markups between wholesale and retail levels for the U.S. and West Germany (the only uncontrolled foreign retail market identified). These comparisons are considered tentative primarily because consistent data were not available for a "benchmark" period prior to the imposition of U.S. controls. Given this caveat, our estimates indicate that U.S. markups were, on average, $3.4 \$ /$ gallon lower than markups in West Germany in 1976-1977. Comparisons with individual cities indicate that these differences are statistically significant with respect to two of the four U.S. cities considered. However, lack of a benchmark period and our inability to adjust fully for differences in general tax policies (as opposed to specific taxes on petroleum products), environmental controls, and refinery yields indicate that differences in estimated markups are well within the bounds of confidence one can place apon the underlying data. 
Chapter 1

HISTORY: OF PRICE CONTROLS ${ }^{1}$

The petroleum industry -- or more specifically the crude production segment of the industry -- has been subject to government regulation for the last forty years. In 1935, the major producing states signed the Interstate $0 i 1$ Compact to Conserve $0 i 1$ and Gas. The major producing states developed a system of market demand "prorationing" under which producers were permitted to produce only a specified percentage of "basic maximum allowables" which vaguely related to the maximum efficient rate (MER) of production. Under the market demand prorationing programs, state agencies set the rate of allowables at a level designed to meet expected demand at a desired price. The level of permissible production was normally set much below 100 percent. The fixing of maximum output for all producers had the effect of stabilizing prices as well as the effect of eliminating competition among producers of crude $0 i 1$.

In the mid 1950's, the increasing availability of low-cost foreign crude threatened the viability of the domestic prorationing system and the pattern of relatively stable prices. In 1959, President Dwight D. Elsenhower, by proclamation, established the Mandatory 0il Import Program (MOIP), which set volumetric limits on the amount of crude oil and products which could be imported into the United States. The effect of MOIP was to insulate the price of American crude oil from lower world prices. Since there was a relatively fixed ceiling on imports of crude 0i1, the marginal barrel of oil needed to supply domestic demand came from domestic sources. Thus, the price of domestically produced petroleum set the price charged to domestic consumers. The domestic production 
of crude oil peaked in 1970. In 1972, the conservation agencies of the producing states set the allowables under prorationing at 100 percent. Consequently, there is no longer any "spare capacity." Domestic producers produce as much petroleum as is profitable under the current regulatory framework.

\subsection{The Current Regulations}

Phase I. On August 15, 1971, President Nixon froze all prices and wages except for prices involving the first sale of agricultural and imported products. The purpose of Phase I of the Economic Stabilization Program was to combat widespread and accelerating inflation. Phase I ended on November 14, 1971 and was followed by Phase II of the program which was designed to hold average price increases to no more than three percent annually throughout the economy. It should be pointed out that Phase I and Phase II regulations were not specifically instituted for the petroleum industry but were general to the whole economy.

During Phase I, ceiling prices for petroleum products were set at the highest prices charged for at least 10 percent of the sales that occurred during 30 days prior to August 15, 1971. However, ceiling prices were no less than those prices prevailing on May 25, 1970.

Phase II. Under Phase II, the Price Commission was created and given responsibility for administering oil price regulations. Ceiling prices set during Phase I became base prices during Phase II. 0il companies could charge prices above base prices if (1) the price increases were cost justified, and (2) profit margins during the year did not exceed those during the base period. The base profit margin was defined as the ratio of the average of the highest profits before taxes to net sales for two of the last three fiscal years prior to August 15, 1971. 
In an effort to simplify the administration of controls, the Price Commission granted Term Limit Pricing (TLP) agreements for certain refined products, i.e., companies were allowed to increase the prices of these products for a specified period of time provided that weighted price increases were consistent with cost pass-through and profit-margin rules. However, certain refined products -- gasoline, number 2 heating oil, and residual fuel oil were excluded from TLP agreements. Crude oil sold by refineries was also excluded. Together, these excluded products accounted for nearly three-fourths of the total U.S. refinery yield.

Phase II regulations allowed prices of imported products to be charged directly to customers. This was, however, allowed only if imported products were physically segregated from domestic products all the way through to the ultimate customer. Because of nonexistence of duplicate tank and pipeline facilities, producers and purchasers found this difficult to apply in practice.

Price relationships for oil products not subject to ILP agreements, which were frozen during Phase I, remained frozen during much of Phase II, i.e., prices of number 2 heating oil and gasoline remained virtually constant at mid 1971 levels throughout 1972. TLP agreements were allowed to expire at the end of Phase II.

Phase II rules severely restricted flexibility in adjusting relative prices. on products excluded from TLP agreements. Because the majors could not follow seasonal pricing patterns and raise heating oil prices as winter approached, refiners had no incentive to increase the output of heating oil during the fall months. Therefore, during winter of 1972-73 regional shortages of heating oil began to develop. 
Phase III. Phase III lasted from January 11 to June 13, 1973. The initial purpose of the regulations during this Phase was to give the industry greater flexibility within the price guidelines established by the government. The profit margin definition was extended to include highest profits for any 2 of 5 years between 1968 and 1972. In addition, relief from profit margin limitation was given to firms that restricted price increases to less than $1.5 \%$ per year. The Price Commission was abolished and the Cost of Living Council was expanded to administer the program.

Immediately following the issuance of Phase 3 regulations, there was a sharp jump in prices, particularly in home heating oil. The reason for the price increase was that allowed January price increases permitted the industry to pass on cost increases that had accumulated during previous 17 months.

However, under pressure, the Cost of Living Council issued the more restrictive Special Rule 1 on March 6, 1973. This rule imposed mandatory price controls on crude oil and refined product sales of any firm with annual gross sales of more than $\$ 250$ million. This rule affected twentyfour major oil companies. This rule allowed these companies:

a) increases of product prices of up to 1 percent (annual1y) without justification

b) increases of up to 1.5 percent (annually) corroborated by cost increases

c) increases of over 1.5 percent subject to a profit margin constraint.

Special Rule 1 also hastened the destruction of the quota system for importing crude oil. Under the old quota system, refiners were issued 
tickets authorizing specified levels for importing crude oil. The sale of tickets had become a major source of income for small and independent refiners. As long as world crude prices were below the U.S. prices, small refiners were able to sell these tickets to the majors. By early 1973, world crude prices were rising while domestic prices were frozen. Consequently, the value of import tickets fell sharply.

Major oil companies had little incentive to import and exchange crude oil because of Special Rule 1. Therefore alleged shortages of crude oil for small refiners started to develop. Many small refiners, denied domestically produced crude oil, began to lobby for crude oil allocation programs under which they could obtain a "fair share" of crude oil supplies.

The Phase III program terminated on June 13, 1973 with the institution by the President of a sixty-day price freeze. During this period increased costs of imported crude ofl could not be passed through to consumers. With rising foreign crude oil prices, this probably discouraged some imports of crude oil and contributed to product shortages during the Fall of 1973. Limited cost pass through provisions were allowed for refined products if these products were sold without any change. However, the regulations still prevented the physical commingling of imported and domestic products in storage or pipeline and because of this, were little help to the industry.

\subsection{Regulations During Phase IV and After}

Phase IV took effect on August 13, 1973. . One of the most significant improvements in its regulations was a meaningful cost pass through provision for crude oil and petroleum products. Imported oil was allowed to be commingled with domestic oil and sold at a weighted-average price. The drafters of Phase IV regulations devised a comprehensive set of regulations 
to govern the price of petroleum and its products by each segment of the industry: producers, refiners, resellers, and retailers.

\subsubsection{Producers}

In an effort to encourage new production, the Cost of Living Council established a two-tier price system for crude oil. Four classes of crude oil were established.

1. 01d 0i1. Level of production from each property month-by-month during 1972. This oil was to be sold at the posted price of May 15, 1973 plus an amount not in excess of thirty-five cents. The cost of Living Councit in mid-December 1973 allowed an increase of $\$ 1.00$ per barret in the ceiling price. This led to the 1975 average of $\$ 5.25$ per barrel for old oil.

2. Stripper $0 i 1$. Output from those properties that produced less than ten barrels per day. After November 16, 1973, stripper oil was exempted from crude price regulations.

3. New 011. Any further production from each property and output from fields not yet producing in 1972. This oil was not subject to price controls.

4. Released 0il. The amount of old oil matched by new production from each property. This category of crude oil was exempted from price controls and was equivalent to the amount by which current production exceeded the 1972 base level.

As a result of the two-tier price system, nearly 40 percent of all domestic oil in the United States was deregulated. However, these regulations did not assign the buyers (refiners) property rights to crude oil. These regulations, therefore, resulted in significant differences in the amount of crude oil available to competing refiners as well as in 
substantial differences in the cost of available crude oil.

Following passage of the Emergency Petroleum Allocation Act of 1973 (EPAA), the FEO announced new regulations on January 15, 1974, effective immediately. The EPAA established property rights to valuable 01d 0il by giving those rights to the refiners purchasing that oil on December 1 , 1973. The regulations froze supplier/purchaser relationships between crude producers, refiners, wholesale resellers of petroleum products and retailers. The regulations also established base period volumes generally reflecting a period within 1972. The FEO established a special program, called the "buyer/seller" program to equalize the quantity of crude oil available to each refiner in relation to their refining capacity. Under this program, refiners having a higher percentage of crude oil supplies available than the national average were required to sell their crude to refiners with below normal crude availability. On May 14, 1974, the buyer/seller program was revised to limit the class of sellers to the fifteen largest integrated refiners, with only the small refiners defined as eligible buyers.

The buyer/seller program solved the problem of availability of crude to refiners; yet a substantial disparity between the amount of old oil available to varfous firms existed. Consequently, the average price that refiners had to pay for their crude varied greatly, depending on the proportion of old and new crude oil used as inputs. The differential in the new and the old crude prices subsequently resulted in the implementation of the "Entitlements Program" on December 4, 1974.

The Entitlements Program tended to equalize the average cost of crude $0 i 1$ across refiners. The Federal Energy Administration (FEA) issued entitlements to refiners each month and also set the price of entitlements. The price was approximately equal to the difference between the cost of all uncontrolled oil and the 
average cost of controlled oil. The total number of entitlements issued to a refiner equalled the total oil used by the refiner times the industry fraction of old oil to total crude oil (approximately 0.4 for 1974-76). Firms issued fewer entitlements than the actual old oil used were required to purchase additional entitlements from other refiners. Small refiners were allowed to apply for exemption from this obligation. The effective price of crude $0 i 1$, therefore, became a weighted average price of controlled and uncontrolled oil prices.

EPAA of 1973 remalned virtualiy unchanged for two years. The Energy Policy and Conservation Act (EPCA) of 1975 made some basic alterations and several minor accounting adjustments in controls. The crude oil pricing regulations of EPAA were superseded in February 1976 by the provisions of EPCA of 1975 . The main alteration was to establish a three tier pricing program for domestically marketed crude oil.

1. Lower tier oil: Output from an oil field which is not in excess of that field's 1975 average monthly output of old oil or its 1972 average monthly output of all oil.

2. Upper tier oil: Output in excess of lower tier oil and from fields not producing prior to 1976. Stripper oil was originally defined to be upper tier oil, however, in September 1976, stripper oil became uncontrolled.

3. Highest tier oil: Stripper oil after September 1976, and imported crude oil, which had never been subject to U.S. price controls. EPCA provided for the phasing out of price regulations on crude oil over a forty month period. It established a fixed national average price of crude oil which was permitted to escalate gradually over time. FEA was given discretion to establish various price tiers to achieve the national average price level. 
The lower tier crude price was retained at the same level as old oil, i.e., approximately $\$ 5.25$ per barrel plus some small monthly incentives and inflation adjustment factors to be determined by FEA. The price of upper tier oil was set at $\$ 11.28$ per barrel (about 10\% below world market prices) plus monthly adjustment factors. FEA was given discretion to increase the average price for all crude initially set at $\$ 7.66$ per barrel, up to 10 percent per year. Price increases beyond this level were to be submitted to Congress for approval.

In order to accommodate the new price provisions, entitlements became allotted upon a weighted industry average of lower and upper tier oil relative to total consumption, instead of the domestic use of old oil to total oil. Entitlements were also given to refiners on the East coast who imported residual fuel. In determining the price of entitlements, the FEA provided a $21 \$$ per barrel incentive for the use of domestic crude $0 i 1 .^{2}$ This preference reflected the $21 \notin 1$ icense fee imposed on imported crude oil. However, for some refiners importing crude oil under the quota system, the preference amounted to only $10.5 \$$ since they were not subject to license fees but. were subject to import fees which amounted to $10.5 \$$ per barrel.

\subsubsection{Refiners, Resellers and Retailers}

August 17, 1973 --

Initial Phase IV regulations established May 15, 1973 as the base period for prices charged by refiners, resellers, and retailers. Refiners were allowed to recover increased raw illaterial costs only on a dollar-for-dollar basis. Increased crude oil prices were spread across refined products on the basis of volume of output ratios. These rules applfed to all sales by refiners to wholesalers, jobbers and retailers of 
their product.

Retail sales of gasoline, number 2 heating $0 i 1$, and diesel fuel were also placed under controls. The basic means of control was, at this time, a ceiling price. Except for these three products, with a price ceiling at the retail level, retailers and resellers could charge the purchase price of petroleum products plus their May 15, 1973 mark-up.

The ceiling price for gasoline became effective on August $31,1973$. The ceiling price was defined as the average cost on August 1, 1973, plus the average mark-up on january 10, 1973. However, in computing the retail price of gasoline, retailers were allowed to use an actual mark-up of $7 \$$ per gallon. This was done to avoid any hardship to retailers who were engaged in price wars in January 1973.

September 28 , $1973--$

Retailers of gasoline, diesel fuel and home heating oil were allowed to increase their ceiling price over the May 15, 1973 level to reflect increased product costs of imports, domestic crude, and purchased products incurred during May 15 to September 1973. In October an upward ceiling adjustment was authorized to reflect increased product costs incurred up to October $15,1973$.

October 31,1973

The regulations permitted pass-throughs of increased raw material costs, on a dollar-for-dollar basis, for gasoline, diesel fuel and home heating oil at all Tevers of distribution; on a once-monthly basis.

December 3, $1973--$

New regulations were issued, effective November 30,1973 , requiring refiners to include all product cost increases in the calculation of product cost pass-throughs. Previously, refiners reselling imported 
products could pass through increased costs of high-cost imported products directly to independent retailers, while at the same time selling their own domestic refined products through branded dealers at lower prices.

January 15,1974

The FEO issued mandatory price regulations allowing refiners to pass through net increases in allowable costs, on a dollar-for-dollar basis. Refiners were allowed to pass through increased nonproduct costs but only if they prenotified FEO of this increase and did not receive disapproval within 30 days. Increases in product costs could be passed through on a "dollar amount" basis. Refiners were allowed to pass through increased nonproduct costs only on the basis of the rate at which these costs had increased relative to refinery output, rather than on a flat dollar amount basis. In addition, refiners using nonproduct cost passthrough provisions were subject to profit-margin limitations.

Retailers and resellers were allowed to charge the average May 15, 1973 price plus an amount reflecting increased product costs on a dollarfor-dollar basis. These increases were to be passed along once a month. In addition, with respect to retail sales, a seller was allowed to charge an extra $1 \$$ per gallon to reflect increased nonproduct costs (as of January 1974). With respect to all other sales of gasoline, sellers were allowed to charge an extra $1 / 2$ cent per gallon.

Refiners, resellers, and retailers were also allowed to "bank" their increased costs if these costs were not recouped during the month in which they were incurred. Banked costs could then be used to justify future price increases.

March 1, 1974 --

Retailers receiving less than $85 \%$ of their base period volumes were 
allowed to increase the price of gasoline by $1 \$$ per gallon. In addition, all retailers were allowed to increase gasoline prices by $2 \$$ per gallon to reflect increased nonproduct costs.

December 1, 1974 --

The FEA provided for eight categories of increased nonproduct costs that could be passed through by refiners without prenotification. The regulations required that increased nonproduct costs for each category be calculated by a particular method. For some categories the amounts were calculated by a simple difference in the costs incurred in the month of measurement and costs incurred during May 1973. In other categories, amounts were calculated by methods which take into account changes in refinery output.

January $1,1975--$

Regulations were issued affecting the manner in which "banked costs" could be recouped. Limitations were adopted regarding the amount of banked costs that could be recovered in a single month.

July $30,1976--$

FEA proposed new regulations which provided additional categories of nonproduct cost pass-throughs, a revision of existing nonproduct cost categories, and simplification of the method for calculating increased nonproduct costs .

Additional categories of increased nonproduct costs includes: depreciation costs, maintenance costs, and Federal, state and local taxes. Under these revisions, refiners were permitted to pass through, as nonproduct costs, all depreciation costs associated with capitai investment undertaken since May 15, 1973, for refining and storage. The maintenance category was increased to permit pass-throughs of labor costs as well as increased costs of supplies used in maintenance operations. Finally, 
any increase in Federal, state and local taxes excluding income taxes, since May 1973, were allowed to pass through to product prices.

Under previous regulations, the increased cost of crude attributed to a particular product was based on the ratio of sales of that product to sales of all products during a month. In these revisions, an alternative allocation factor was proposed, which allocated input cost increases to various products on the basis of refinery output.

The method for calculating increased nonproduct costs was also simplified. Those refiners whose output did not change substantially (less than $10 \%$ growth) since May 1973 could compute increased nonproduct costs by using the difference in these costs during the month of measurement and May 1973. A more detailed procedure was required for refiners whose output changed substantially when compared to May 1973; the latter procedure adJusted for refinery output changes.

At about the same time, prices for several petroleum products, including residual fuel oil, home heating oil, and diesel were exempted from price controls. Motor gasoline prices, however, remained subject to federal regulation. 


\section{Chapter 2}

\section{A REVIEW OF THE LITERATURE ON PRICE CONTROLS \\ IN DOMESTIC ENERGY MARKETS}

This historic evolution of price regulation outlined above attests to the complexity of controls placed upon energy markets. Several authors have attempted to analyze the effects of these controls on domestic and imported supplies of crude oil and refined products, upon final product and input prices, and on profits of firms involved in various stages of production. Foremost among these analyses are studies by Kalt (1977), Phelps and Smith (1977), Roush (1976), and Chapel (1976). The results obtained and methodologies employed by these authors are reviewed in detail below. Although the conclusions of these studies agree in several areas, there remain significant and important points of conflict. In large measure, these disagreements are due to complexity in the nature of price control regulations, and ambiguity over the exact way in which they were implemented. In addition to the four studies cited above, there have been a number of less significant contributions to the literature, e.g., Ha11 and Pindyck (1977), Friedman (1975), Federal Energy Administration (1975), Yang (1977) and Cox and Wright (1978). In general, the latter studies were rather limited in scope and depth. Thus, they are not surveyed in detail, but are cited whenever their conclusions differ from those offered in the four primary studies.

\subsection{Summary of Major Findings of Past Studies}

This section provides a brief summary of the major conclusions obtained in Kalt (1977), Phelps and Smith (1977), Roush (1976) and Chapel (1976), and highlights areas of controversy. Authors of all four studies 
conclude that price controls on crude oil implemented under the Emergency Petroleum Allocation Act (EPAA) had an ambiguous effect on domestic crude oil supply, while the temporary crude oil tariff of 1975 tended to increase domestic supply. On the other hand, crude oil price controls under the Energy Policy and Conservation Act (EPCA) unambiguously reduced the domestic supply of crude oil. The effects of controls on refined products are more controversial. Phelps and Smith argue that none of the policies implemented since EPAA took effect significantly affected the domestic price of refined petroleum products. Their argument stems largely from evidence that refined products have been imported into the U.S. throughout this period. On the other hand, Kalt concludes that refined product price controls were largely ineffective (except in late 1973 and early 1974), but that the Entitlement: Program served to reduce refined product prices in the United States. Roush disagrees with both of the above and concludes that EPAA controls on refined products may well have reduced retail prices and, due to the nature of allowed cost pass-through provisions, avoided queues. Under provisions of EPCA and the Entitlement Program, Roush argues that refined product price controls with simple cost passthrough provisions would probably have heen redundant, but that complexity and rigidity in actual implementation of these provisions may have given rise to spot shortages in particular areas and periods. The following pages of this chapter briefly outiine the analysis leading to these conclusions and highlight the areas of important controversy. Because the pattern of regulation was highly volatile prior to passage of EPAA and associated refined and retail market controls in late 1973, the discussion is confined to analysis of regulatory effects from this time forward. 


\subsection{The Effect of Controls on Crude 0il Markets}

The preceding chapter outlined price controls for four different categories of oil (old, new, released, stripper) instituted under PHASE IV and EPAA. 'These controls placed no restriction on the price at which stripper oil (which represented about 13 percent of domestic production in 1973) could be sold. Hence, the controls did not affect the supply of oil from such properties. In the absence of released oil provisions, EPAA would have tended to redure domestic supply. Marginal barrcls of crude oil from any property producing in excess of its corresponding 1972 level would have sold at the uncontrolled price; only those barrels that corresponded to 1972 production levels were controlled. Thus, the output from such properties would have been unaffected by the controls. On the other hand, marginal output from properties producing less than their 1972 levels would have sold at the controlled price of about $\$ 5.25$ per barrel. If the supply of oil from such properties displays any elasticity, removal of the price control would have led to increased production. On balance, then, such controls would have reduced domestic supply. However, the rather peculiar provisions for "released oil" in EPAA regulations make the net result on domestic supply unclear. In effect, the marginal revenue obtained from selling a barrel of released oil (which represents production from old properties in excess of the historic 1972 level) excoeded the uncontrolled price hy an amnunt equal to the difference betwecn uncontrolled and controlled prices. During the 1974 to 1975 period, this difference was approximately $\$ 6$ to $\$ 8$ per barrel. This feature, no doubt, induced increased production from some old properties, particularly those with relatively low and elastic marginal costs. Whether or not this effect was sufficiently strong to counteract the reduction in supply from high 
cost old properties, caused by old oil price controls, is not clear. During the two-year period in which EPAA regulations were in effect, tariffs on crude oil imports were introduced. Initially set at $\$ 1$ per barrel in February 1975 , the import duty was raised to $\$ 2$ per barrel in May of that year and remained at that level until December 1975, when the entire tariff was discontinued. A11 analysts agree that the expected effect of the tariff would be to induce refiners to substitute away from imported oil and toward domestic supplies. This increase in demand for U.S. output would cause the price of uncontrolled domestic crude oil to rise until both domestic and imported crude oil prices were equalized (allowing for differences in quality and transportation cost). None of the studies reviewed have analyzed these effects in detail. However, Roush noted a persistent price differential between imported and uncontrolled domestic crude oil that varied between $\$ 1$ and $\$ 1.60$ per barrel during the tariff period, with imported supplies carrying the price premium. Evidently, a price spread of this magnitude cannot be entirely explained by quality differences or transportation costs. Roush argues that the phenomenon was probably the product of two forces. Since domestic sellers are often physically connected (e.g., by a pipeline) to buyers, recontracting with new buyers is costly; thus, domestic price responses may be sluggish. Further, the legality of the * import fee was in doubt during this period and tariff revenues were being held in escrow pending a final court decision. Thus, buyers may have attached a significant probability to a refund of import fees paid, and consequently been willing to pay more for imported oil.

The old oil allocation program which allocated rights to pricecontrolled old oil under PHASE IV and EPAA regulations, was superseded in late 1974 by the Entitlements Program. The effect of the entitlements 
scheme was to essentially set the price of all oil purchased by refiners at the average price of old oil and uncontrolled oil. From the refiner's point of view, this effectively raised the price of old crude oil and lowered the price of uncontrolled oil. Since marginal supplies of crude oil were in the uncontrolled category, the Entitlements Program reduced the price of marginal crude oil inputs, by $\$ 2$ to $\$ 3$ per barrel during 1975 according to estimates by Phelps and Smith (1976). All analysts have concluded that this crude oil price reduction increased the domestir. supply of refined products (shifted the supply schedule out) and lowered refined products imports to the United States. According to Chapel (1976) as well as Phelps and Smith (1976), total imports of refined products fell about 16 percent (by volume) as a result of the Entitlements Program.

The effect of Entitlements on domestic product prices is however less clear (analysis of final product prices is presented in more detail below). Phelps and Smith argue that the foreign supply of refined products to the U.S. is perfectiy elastic. Noting that refined products continued to be imported before and during the Entitlements Program, they conclude that this program had no effect on domestic product prices, i.e., that domestic refined product prices are effectively set in the world market. Kalt, on the other hand, argues that imports of several important refined products (including gasoline) are negligible and exert no significant influence on domestic prices. Implicitly, he estimatęs that the Entitlements Program reduced domestic prices by 2.5 cents to 3.5 cents per gallon. Roush appears to agree with the basic thrust of Kalt's argument, but offers no empirical evidence. In addition to these influences, the change in rights to old oil instituted under the Entitlements Program redistributed rents away from those refiners who initially had access to price controlled old o'il, and toward other refiners and producers of marginal oil supplies. 
The final set of crude oil policy changes analyzed are the price control provisions of EPCA, enacted in December 1975 and instituted in February 1976. By this time, the crude oil import tariff had been removed. EPCA maintained the original price freeze on old oil, but did away with the bounty on released oil. Further, new oil and oil formerly categorized as released oil were subjected to a price ceiling of about $\$ 11$ per barrel. The only oil allowed to sell at uncontrolled prices was that forthcoming from domestic stripper wells (after September 1976) and imports. As all authors agree, the theoretical effect of such a policy is to reduce domestic supply, when compared to the earlier EPAA policy, and in comparison to an uncontrolled situation. As a consequence, domestic dependence upon foreign oil supplies is increased. None of the analysts have, however, provided estimates of the magnitude of these effects.

\subsection{Refined Product Markets}

Since the focus of this study is on final product price regulations, the results of past analysis on this topic are reviewed in more detail than those for crude oil markets. Further, since the resuits of various authors disagree in several important respects, and since different studies have considered product price regulations in differing degrees of scope and depth, it was found convenient to review this past research on a study-by-study basis. As before, the analysis is confined to regulations adopted since October 1973.

\subsubsection{The Phelps-Smith Report}

In several respects the analysis undertaken by Phelps and Smith is the most extensive available on the topic of petroleum industry regulations since 1973, both in terms of the scope of issues covered and the depth of theoretical and empirical analysis. The basic conclusions 
reached by these authors can be briefly summarized. While price controls held refined product prices below equilibrium levels in late 1973 and early 1974 (approximately through March of that year), they have had no appreciable effect on domestic prices of refined products since that time. They have, however, altered international trade patterns in refined products and crude oil and have redistributed profits (rents) among firms in the industry. The arguments leading to these conclusions are summarized below.

Phelps and Smith begin their analysis by constructing a stylized theoretical model of world markets in crude oil, other refinery inputs, and final petroleum products. Their purpose here is evidently to demonstrate that, at a theoretical level, it is quite possible that price controls (under PHASE IV and after) with allowed cost pass-through provisions will not place a real constraint on the market, i.e., that allowed price increases may well exceed unrestrained market price increases. The basic thrust of their argument may be expressed in the following equations. If $C$ is the refining industry's marginal cost of output (an aggregate of refinery products), $r$ is the price of crude oil input, $v$ is the price of another (aggregated) refinery input, and $Q$ is the industry's output of refined products, then

$$
C=C(r, v, Q)
$$

which represents the refining industry's marginal cost function. Phelps and Smith assume that production takes place at constant returns to scale which implies that $C$ is constant with respect to output $(Q)$ and that

$$
\Delta C=(x / Q) \Delta r+(y / Q) \Delta v
$$

where $x$ and $y$ are, respectively, amounts of crude oil and the other input used in the refining process and $\Delta$ denotes a change in a variable. Thus, 
if $r$ increases by one unit, marginal cost will rise by an amount equal to $x / Q$, the input-output ratio for crude oil. Actualiy, the expression in (2) requires only that the production function is homothetic, a weaker assumption than constant returns. Further, (2) holds only for arbitrarily small changes in variables and must be considered an approximation for Targer changes.

The basic thrust of allowed cost pass-throughs under PHASE IV is that the maximum price of a refiner's output is allowed to rise above the base period level (May 1973) by an amount equal to the rise in crude oil input price times the input-output coefficient for the refined product in question. Thus, if the price of crude oil rises by $\Delta r$, the allowed product price increase is

$$
\Delta \bar{P}=(x / Q) \Delta r
$$

where $\vec{P}$ is the maximum allowed price. Within the Phelps-Smith analysis is 'an implicit assumption that refined products are sold competitively in a single market so that price $(P)$ equals marginal cost $(C)$. Intuitively, then, if allowed price increases are sufficient to offset the upward shift in supply from input price increases, the controls will not be binding. Comparing (2) and ( 3 ), it can be seen that

$$
\Delta P-\Delta C \geqq 0 \text { if } \Delta v \leqq 0
$$

In general equilibrium, a change in crude oil price $r$ (e.g., from OPEC cartelization) will have an influence on $v$, the price of the other refinery input. Within the context of their simplified model, Phelps and Smith demonstrate that the secondary effect of a rise in the price of crude oit ( $r$ ) will, in all likelihood, be to reduce $v$. Thus, from (4) the prediction that $\Delta \vec{P}>\Delta C$ emerges; by ignoring changes in prices of other inputs, 
the price regulation will not tend to be binding.

In this simplified model, the input ignored in the price control formula is capital. Prior to 1976, pass-throughs were allowed primarily for crude oil and refined product inputs only. Such capital related expenses as overhead, some maintenance outlays, facility expansion, desulfurization equipment, etc. were not included in the pass-through formulae. Simply stated, Phelps and Smith argue that the price of such capital inputs fell in the control period and that the price control formula did not account for this input price decrease.

At this juncture it is worthwhile to reemphasize some key assumptions leading to this conclusion. First, it is assumed that refined petroleum products are sold in a single competitive market at a single price equal to marginal cost; regional sub-markets with differential degrees of monopoly are not allowed. Second, production takes place at constant returns to scale, an assumption that is not really critical to the above conclusions, but one which takes on more importance below. Third, the supply of factor $y$ is upward sloping to the industry. That is, the non-crude oil factors of production (primarily capital) are specific to the refining industry in the sense that a decrease in the refining Industry's demand for them (due to a change in relative factor prices or a fall in output) will reduce their prices.

In addition to the effects described above, Phelps and Smith note other influences which will either raise or lower the tendency of the price constraint to be binding. Probably the most important of these is that pass-through formulas allow only the average price of crude oil purchased to be passed through. During the period when firms were effectively able to purchase old oil at a price substantially below the market price of marginal oil supplies (prior to the Entitlements Program), this tended 
to increase the bindingness of the constraint. Since the price of marginal oil was rising, the average price tended to rise slower than the margin, and marginal price is a relevant item in the marginal cost formula (see (1) and (2)). Further, they note that if the market price of $v$ tends to drift up (e.g., due to inflation or rising incomes) this will tend to tighten the price constraint, and conversely for factors (such as productivity increases) that tend to lower $v$. Also, the crude oil tariff of 1975 raised the price of crude oil and the marginal cost of refined products, and allowed domestic price increases for refined products. However, as Phelps and Smith point out, the tariff did not influence the prices of refined products in international markets, and under their hypothesis international prices set domestic prices. Thus, they conclude that the tariff reduced the tendency of U.S. petroleum product price controls to be effective. (Curiously, they do not discuss the effect of the refined product tariff which was instituted simultaneously with the crude oil tariff.)

Considering all of the factors discussed above (as well as empirical evidence reviewed below), Phelps and Smith conclude that "the price ceilings have been non-binding since 1974." (Phelps and Smith, p. 22). The preceding analysis of price controls on refined products was rather cursory in that it did not include provisions for "banked costs," application of cost increases on one refined product to other refinery outputs, profit margin constraints, and allowances for cost pass-throughs for imported refined products. These provisions are discussed below.

In addition to the price limits described above, petroleum refiners were subjected to profit margin constraints under PHASE IV controls. ACcording to Pheips and Smith, the profit margin constraint was stated as the ratio of net revenue to total sales in an historic (pre-embargo) period. 
Thus, final product prices were constrained to be such that the net profit margin on sales did not exceed this historic level. Given the constant returns to scale assumption employed by. Phelps and Smith, input cost shares sum to unity and net revenue becomes the (explicit or imputed) payment to capital in the industry, i.e., net revenue is, in a true economic sense, a cost of production. Under very reasonable assumptions on the opportunities for factor substitution in the refining process (specifically, the assumption that the elasticity of substitution between capital and other inputs is less than unity) Phelps and Smith show that a rise in the price of other inputs (crude oil) will lower the cost share of capita1. Thus, given the rapid rise in crude oil costs, capital's share of total revenue would necessarily fall below its historic level. It follows, then, that the profit margin constraint described by Phelps and Smith would not be binding in such a situation. A secondary implication, one not brought out by Phelps and Smith, is that profit margin limits may well be different for different firms if their base period profit margins differed. Price controls placed upon wholesalers and retailers are not directly discussed in Phelps and Smith.

Under the Entitlements Program, refiners' claims to "old" pricecontrolled oil (under EPAA regulations) were reallocated and, in effect, the marginal price of crude oil to the U.S. refining industry was reduced. In essence, the Entitlements Program allocated rights to purchase old oil (at about $\$ 5.25$ per barrel) to individual refiners in proportion to their purchases of uncontrolled oil, including both foreign and domestic suppiies. Implicitly, this program set the price of all crude oil inputs equal to the weighted average of controlled and uncontrolled prices. Thus, the price of marginal (uncontrolled) crude oil was reduced. Estimates provided by Phelps and Smith indicate that the effective subsidy to 
refiners for purchase of uncontrolled oil (new, stripper, and imported oi1) was between $\$ 2$ and $\$ 3$ per barrel in 1975. Two obvious effects of this policy were to increase the demand for crude oil (including imports) and to reduce the marginal cost of petroleum products refined in the United States (see equation (2)). If the U.S. refined product market was isolated, this policy would have led to an increase in refined products supply and a fall in domestic refined product prices. In Figure 1, this effect is seen as a shift in supply from $S_{0}^{D}$ to $S_{E}^{D}$ and a price reduction from $P_{0}$ to $P_{E}$ for refined products.

Al though Phelps and Smith agree that the Entitlements Program shifted the domestic refined products supply curve out, they disagree with the conclusion that domestic prices fell. As they point out, domestic markets were also supplied by imported refined products throughout this period. If the U.S. is a net importer and a price taker for refined products in the world market, then the domestic price is effectively set at the level dictated by world supply and demand conditions. The effect of introducing an elastic import supply (labelled $S_{I}$, with world equilibrium price $P_{W}$ ) is shown in Figure 2. As indicated, the effect of the Entitlements Program in this situation is merely to increase the domestic supply $\left(Q_{0}^{D}\right.$ to $\left.Q_{E}^{D}\right)$ and reduce product imports $\left(Q_{0}^{M}\right.$ to $\left.Q_{M}^{E}\right)$ with no effect on market prices.

In a larger sense, the presence of refined product imports into the U.S. throughout the period studied underlies all of their conclusions on the ineffectiveness of product price controls. If the controlled price lies above the world market price, it will not be binding and the domestic price will remain at $P_{W}$ (see Figure 2). Alternatively, if the controlled price had fallen below the international price, imports into the U.S. would have dried up. Indeed, such a situation would have resulted in refined 
Figure 1

U.S. Refined Products Market (Kalt)

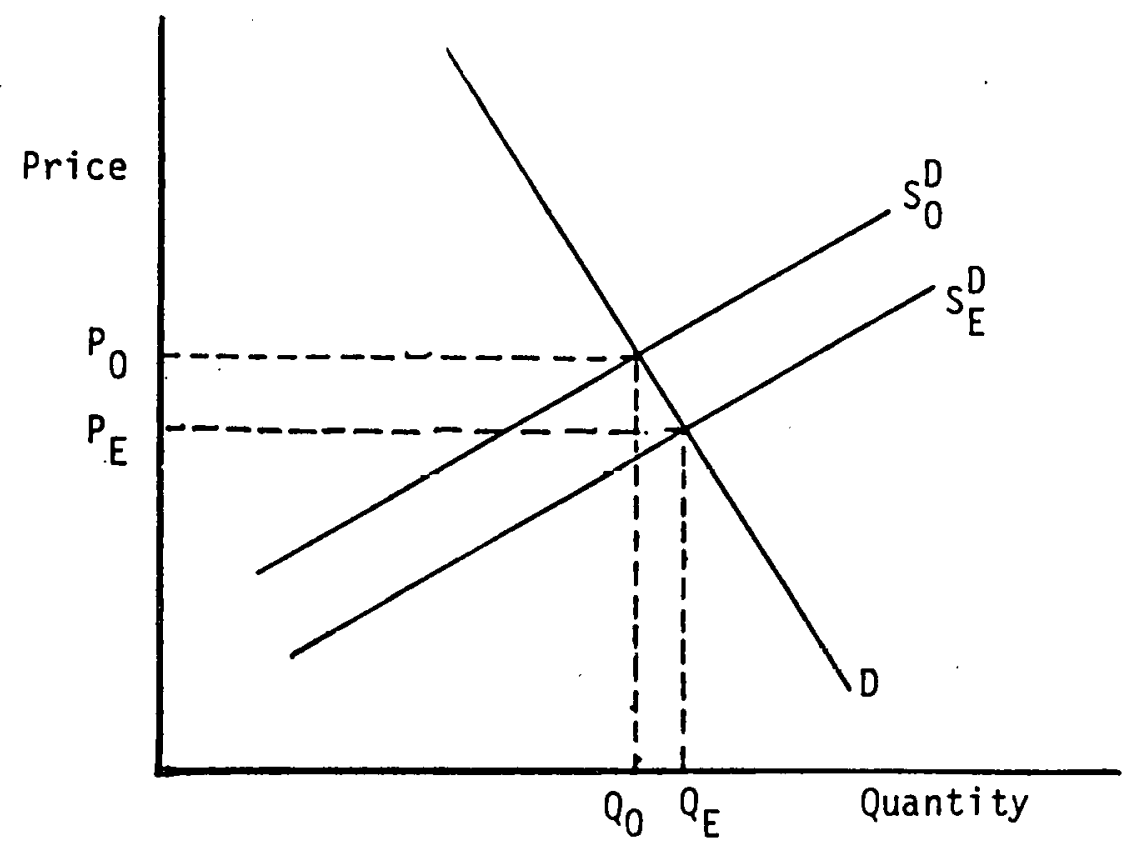

Figure 2

U.S. Refined Products Market (Phelps-Smith)

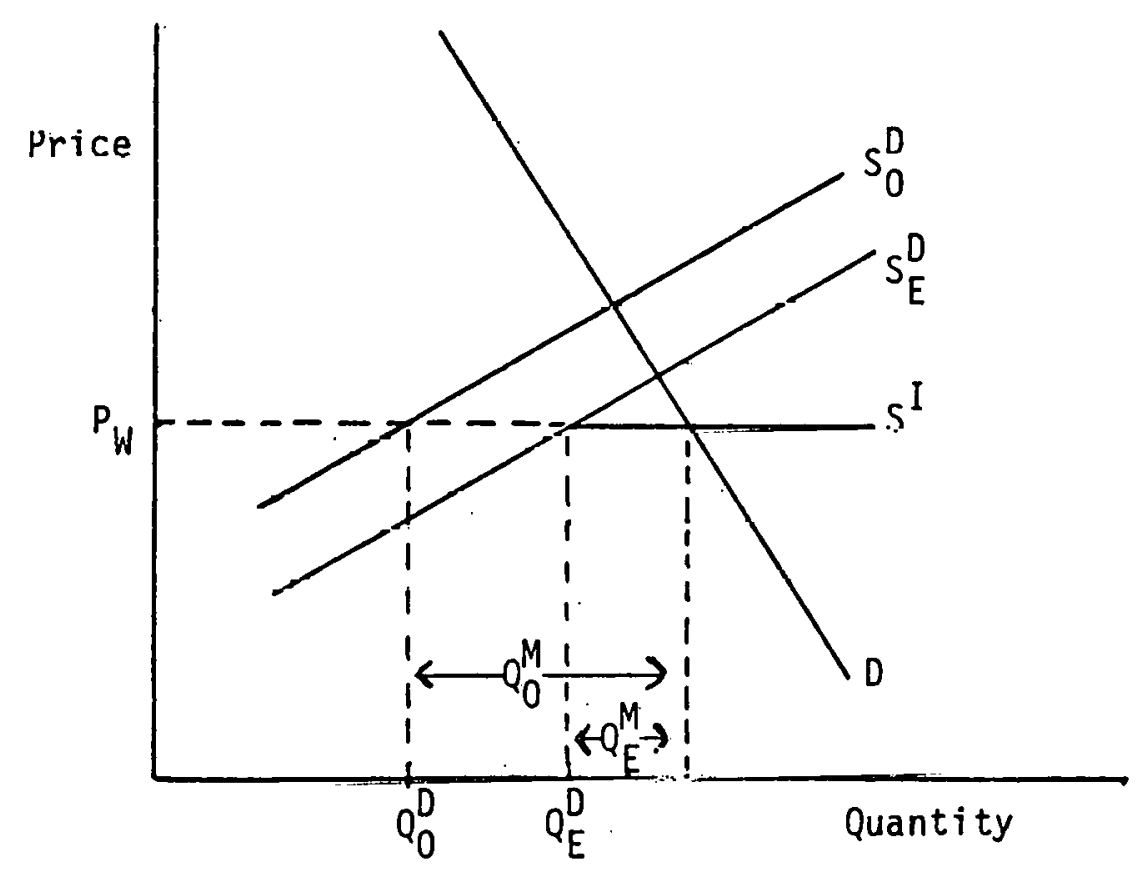


product exports from the U.S. (allowing for appropriate transportation costs) in the absence of strict export controls.

Within the Phelps-Smith paradigm, U.S. policy might have influenced domestic prices only if the U.S. possessed a significant degree of market power in international refined petroleum product markets, i.e., if the supply of product imports to the U.S. were upward sloping. In this case, the expansion of U.S. refined product supply, brought forth by the Entitlements Program, might have reduced our net demand for imports by an amount sufficient to reduce the landed price of such products. This possibility is protrayed graphically in Figure 3 where $D_{0}^{M}$ represents the net demand for product imports in the U.S., ignoring price controls. It is constructed by horizontally subtracting $S_{0}^{D}$ from $D$ in Figure 2; a corresponding net demand for imports under the Entitlements Program is shown as $D_{E}^{M}$. If the supply of imported refined products to the U.S. is upward sloping, as shown by $S^{I}$ in Figure 3 , then enactment of the Entitlements Program would have reduced domestic (and world) prices from $P_{0}^{W}$ to $P_{E}^{W}$. Phelps and Smith provide crude estimates of the possible magnitude of this effect under varying assumptions regarding input. supply elasticities, and elasticlties of final product supply and demand. Inder the set of conditions they feel are most plausible, the Entitlements Program reduced domestic refined product prices by 1 cent to 1.5 cents per gallon. The discussion now turns to empirical issues.

Phelps and Smith provide a variety of empirical evidence to support various points in their analysis. Perhaps the most persuasive data center around "banked costs." Banked costs are aliowed cost pass-throughs (under PHASE IV price control provisions) that have not been exercised by refiners. Presumabiy, if an individual refiner experiences excess demand for his product at a particular price, he would find it profitable to 
Figure 3

U.S. Refined Products Imports (Phelps-Smith)

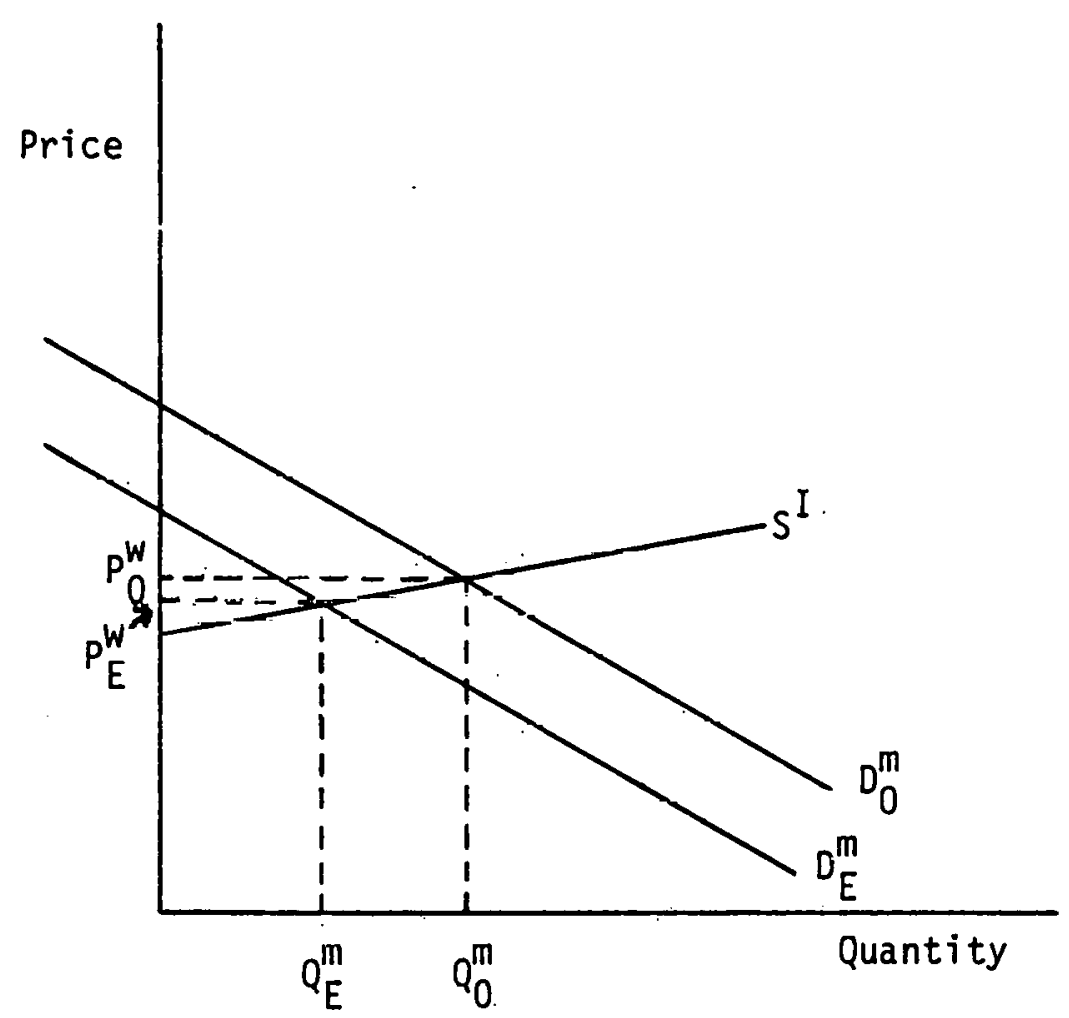


raise that price if such action were allowed under price controls. Data reported in Phelps and Smith.(p. 25) show that aggregate banked costs for the thirty largest firms in the U.S. refining industry were positive throughout the period from November 1973 to December 1975. Banked cost figures (reported as cent/galion) are shown for distillates, gasoline, and other products; for gasoline, banked costs ranged from 1.5 cent/galion to $6.8 \mathrm{cent} /$ gallon during the period. It is notable that banked cost data are shown for the industry, and not for individual refiners, and that reported banked costs for gasoline are positive during late 1973 and early 1974 when queues at service stations were common. These are points to which we shall return. Phelps and Smith also conduct a regression analysis of industry banked costs to identify the statistical determinants of industry banked cost levels. Al though the directions of individual effects are generally consistent with prior expectations, the explanatory power of their econometric model is too low to be considered reliable. To support their contention that the Entitlements Program altered trade flows but did not influence domestic prices, Phelps and Smith provide raw monthly data on relevant variables. In particular, they show that the share of imports in U.S. refined product consumption fell after the introduction of the Entitlements Program. Drawing upon a regression study conducted by Chapel (1976), they estimate that the Entitlements Program reduced refined product imports to the U.S. by approximately 16 percent (see Phelps and Smith, p. 43). They also provide data on monthly average product prices for gasoline and heating oil which show that domestic prices did not fall.with the implementation of the Entitlements Program. However, only raw data on prices are reported and no attempt was made to construct an econometric model to control for other possibie influences. 


\subsubsection{Joseph P. Kalt's Analysis}

Given the extensive discussion of the Phelps and Smith report, the analysis of other authors can te described more briefly since different studies often use similar analytical techniques to study particular phenomena. The analysis undertaken by kalt leads that author to two basic conclusions regarding refined product markets: except for late 1973 and early 1974, PHASE IV price controls on final petroleum products were not binding, and; the Entitlements Program instituted in early 1975 resulted in a significant reduction in domestic refined product prices.

Kalt's first conclusion utilizes data on industry banked costs and casual observation that queues have not been common since March 1974. Considering the formula used to compute refiners' price limits, he concludes that price controls will not be constraining if banked costs are positive. Noting, then, that banked costs at the industry level were positive throughout 1974 and 1975, he concludes that "legal maximum prices have generally been 3 to 6 cents higher than market clearing prices" (Kalt, p. 11). However, queues that were observed in early 1974, and the rather low level of industry banked costs during this period; lead him to conclude that "individual refiners in many markets were undoubtedly compelled to price below market clearing prices and apparently did not have positive banks" (Kalt, p. 12). The latter phenomena are attributed to the fact that cost passthrough provisions were stated in terms of average (rather than marginal) crude oil import costs and that cost adjustments were allowed only after a one month lag. The possible role of profit margin constraints on refiners, mark-up constraints on retailers (and adjustments in these during early 1974), are not discussed.

Although the above conclusions are in broad agreement with Phelps and Smith, Kalt disagrees with these authors on the effects of the 
Entitlements Program. Kalt's analysis of the effect of entitlements upon the refining industry's marginal cost of crude oil, and the resulting effect on the domestic supply of refined products, coincides with Phelps and Smith in that a shift to the right in the domestic refined product supply curve is predicted (see Figures 1 and 2). However, Kalt ignores the influence of product imports upon U.S. prices, arguing that they are an insignificant (and unimportant) supply source. Thus, his conclusions on the effects of the Entitlements Program are summarized graphically in Figure 1. Although Kalt recognizes that actual refined product imports fell (by about 13 percent) after the introduction of the Entitlements Program (as Phelps and Smith predicted), he reports that U.S. imports of gasoline never exceeded 1.0 percent of domestic consumption ${ }^{3}$ either before or after the program was enacted. Kalt provides data on differences between average domestic gasoline prices (wholesale) and landed prices of European exports, but no statistical analysis is offered. According to his estimates, U.S. prices were far below import prices during January-May 1974, which roughly coincides with the period that price controls appeared to be clearly binding. As he points out, industry banked costs were also rather low during this period. Foreign prices fell below domestic prices in the late summer and early fall of that year, but by late 1974 U.S. prices were again lower and remained lower (by about 5 cents per gallon) through mid1976. Kalt makes no attempt to reconcile these price differences with refined product imports observed by Phelps and Smith during this period. Using estimates of the crude oil subsidy implicit in the Entitlements Program, as well as extraneous estimates of other factors, Kalt (impiicitiy) concludes that the Entitlements Program reduced average domestic refined products prices by $2.1 \notin-3.8 \$$ per gallon during this period. 4 


\subsubsection{The Roush (Federal Trade Commission) Study}

The trend of conclusions in the preceding two studies is evident. The first claimed that government regulation of the petroleum industry has had no discernible effect upon domestic retail prices. Kalt agreed with Phelps and Smith in concluding that retail price controls were ineffective (except for a brief period), but argued that the Entitlements Program has reduced domestic retail price levels. Roush concurs with Kalt's finding regarding the influence of entitlements, hut goes a stop further by arguing that PHASE IV price controls (prior to entitlements) may weli have been binding at the retail level even though queues were not observed. Roush also extends the analysis of petroleum industry regulation into other areas as explained below.

The initial sections of Roush's paper are concerned with explaining the allocative effects of price controls under PHASES I, II and III, and the crude oil output effects of PHASE IV controls. Of primary interest, in the present context, is his analysis of refined product price controls under PHASE IV. Under these provisions, the maximum allowed price was the price charged on May 15, 1973 plus the increase in the average acquisition cost of petroleum inputs (primarily crude oil). Certain other product costs were allowed to pass through on a dollar for dollar basis, and constraints on profit margins were imposed, but the analysis of these features is deferred for the moment. During this perind, crude oil was sold at two prices: old oil was sold at a controlled price, denoted $r_{0}$; other oil supplies (new, released, stripper and imports) were available at an uncontrolled price, labelled $r_{w}$. If we assume, for simplicity, that a barrel of oil can be refined at the constant unit cost $m$, and denote the quantity of old oil supplied as $x_{0}$, then the maximum price allowed on refined products is 


$$
\bar{p}=\frac{\left(r_{0}+m\right) x_{0}+\left(r_{w}+m\right)\left(x-x_{0}\right)}{x}
$$

where $x$ is the tontal amount of crude oil currently refined (see Roush, pp. 34-36). To clarify, (5) may be rewritten as

$$
\bar{p}=\left(r_{0}+m\right)+\frac{\left[r_{w}\left(x-x_{0}\right)+r_{0} x_{0}\right]}{x}-r_{0} \text {. }
$$

In (6), $r_{0}+m$ represents the base price of refined products (May 15, 1973). The term in brackets is the average acquisition cost of crude oil in the current period, and $r_{0}$ is, of course, the acquisition cost of crude oil in the base period.

Following other authors, Roush assumes that imported crude oil is in perfectly elastic supply to the U.S. at the price $r_{w}$. Thus, the price of all uncontrolled oil is set by international supply and demand conditions at the level $r_{w}$. If one plots the maximum price function in (6), the result is the curve labelled $\bar{P}$ in Figure 4 . Actually, points to the left of $x_{0}$ are of no practical relevance since they correspond to a situation in which the uncontrolled price of crude oil is less than the ceiling price on old crude. An important point to note in Figure 4 is that the maximum allowed price rises with the output of domestic refined products and that this price approaches $\left(r_{w}+m\right)$ asymptotically. Implicitly, Roush assumes constant costs in the refining industry (with the refinery markup equal to $m$ ) and an elastic supply of crude oil at price $r_{w}$. In the absence of regulation, the supply of refined products would, therefore, be perfectly elastic at price $r_{w}+m$.

Rexamining equation (5) it can be seen that the price limit formula describes the average cost of refined products to the refining industry. This follows from Roush's implicit assumptions that the input-output ratio between crude oil and refined products is unity $(1.0)$ and that production takes place at constant returns to scale. Rearranging equation (5), and setting 
Figure 4

U.S. Refined Products Market (Roush)

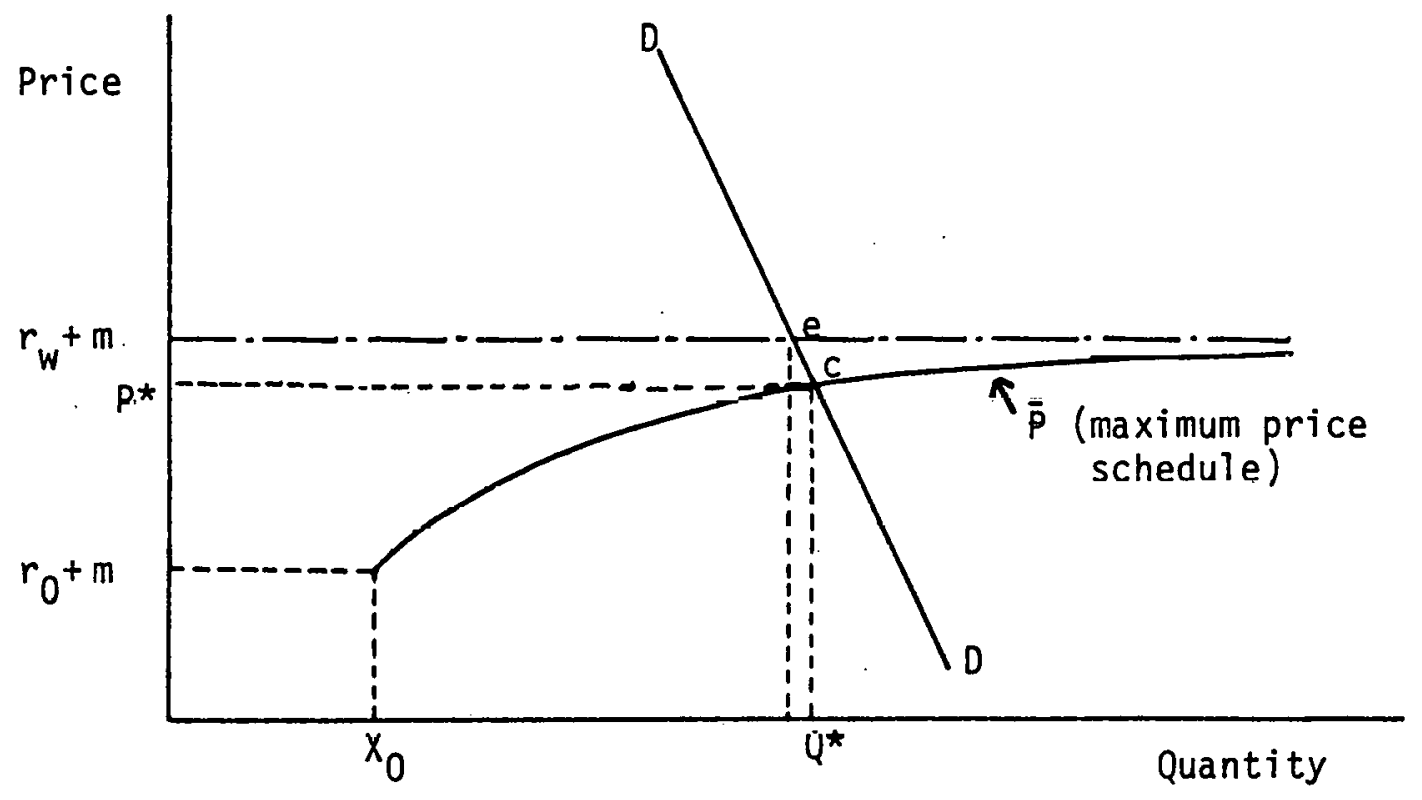


the total volume of inputs $(x)$ equal to the total volume of output (Q) yields

$$
P Q=m Q+\left[r_{0} x_{0}+r_{w}\left(x-x_{0}\right)\right]
$$

$\mathrm{mQ}$ is total refining cost and the term in brackets is industry expenditure on crude oil. Thus, industry costs will be covered at price-quantity combinations along the curve $\vec{P}$. In effect, Roush interprets this curve as an industry supply schedule for refined products under PHASE IV controls. Superimposing the demand curve labelled $D$ on the same diagram, equilibrium occurs at a price $P^{*}$ and output $Q^{\star}$. Firms in the industry are covering costs and the maximum allowed price is being charged, but equilibrium occurs with a lower price and higher output than would be the case without controls. The uncontrolled equilibrium would, in this diagram, occur at the point labelled e. However, this situation is precluded by the legal price ceiling.

As was the case in other studies, Roush's analysis is carried out at the industry level. It is not disaggregated to study the conduct of individual firms. Further, al though industry costs are exactly covered along the curve $\bar{P}$, no reason is given as to why they would choose to produce at the point labelled $c$ (where excess demand is 0 ) rather than at some other point along this price control schedule. ${ }^{5}$

Thus, Roush sharply disagrees with conclusions reached by Phelps and Smith, highlighting the point that with average input cost passthrough provisions, and a two-tier price system for crude oil, refined product price controls could have been binding and could have avoided queues (see Figure 4). Further, he does not take the existence of banked costs at the industry level as positive proof that price controls were not binding. As he notes, the existence of positive banks for the 
industry only indicates that "the pricing constraints of the regulations were not binding for all companies, on all products, at all times . . there are over 100 different refiners producing hundreds of petroleum products and selling them in a number of geographic sub-markets in the United States." (Roush, pp. 40, 41). It is also noted that there were restrictions on fractions of input cost increases that could be assigned to various products, geographic pricing constraints on firms operating in more than one area, lags in the cost pass-through provisions, and limits on how rapidly banked costs could be worked off.

Roush also disagrees with Phelps and Smith (and implicitly concurs with Kalt) concerning the role of refined product imports. Agreeing that the existence of refined product imports into the U.S. is "strong indication that some foreign product was competitive in certain areas of the United States," he goes on to note that "it does not necessarily mean that this was generally the case for all or even most areas or particular products." (Roush, p. 41). To corroborate this point, Roush offers evidence that foreign supplies of regular and premium gasoline as well as gas-oil were priced (landed price) substantially above average prices in various U.S. market centers in 1975 (Roush, p. 43).

Roush's analysis of the Entitlements Program, and the effective subsidy on marginal crude oil afforded to the domestic refining industry, is largely the same as that conducted in the twn previous reports. Concurring with Kalt, he concludes that the effect of the Entitlements Program, by itself, would be to reduce domestic refined product prices from free market levels. However, if refined product price controls were binding prior to the Entitlements Program, as Roush concluded, it is not clear whether the addition of entitlements provisions to EPAA controls 
would have resulted in any further price reductions. The net effect could have gone either way. Thus, he disagrees with the Phelps-Smith conclusion that since refined product prices did not decline after the entitlements Program was introduced, regulatory policy in general had no significant effect on domestic petroleum product prices.

The final analytical section of the Roush study is concerned with the general question of the effect of price controls in a monopolized market. The analysis in this section is general and no specific conclusions regarding refined product price controls are drawn. It is, however, noted that in such a situation, price controls could be effective wi thout introducing shortages of the controlled item. Roush does not argue that complete monopoly is an accurate characterization of the U.S. refining industry, but suggests that outcomes in an oligopolisitc market setting may tend.away from the competitive solution toward the monopolistic outcome.

\subsection{Concluding Comments}

A number of other studies of price controls on U.S. energy markets have not been reviewed in detail. In general, these were either highly simplified treatments, lacked empirical analysis, or focussed primarily on crude oil rather than refined product markets (e.g., Friedman. (1975), Hall and Pindyck (1977)). Other studies looked at product markets and provided empirical evidence, but did not develop a model upon which hypotheses could be based and conclusions drawn (e.g., Federal Energy Administration (1975)).

Among the studies reviewed, only one made a significant addition to the analysis presented in the three works surveyed in Section 2.3. This was a report by Cox and Wright (1978), which focussed upon the 
effect of the Entitlements Program, as modified with the introduction of EPCA, upon the effective price of crude oil to refiners. As they point out, the introduction of two categories of price controlled crude oil (lower and upper tier crude) required a modification of the Entitlements Program. If the program had been altered simply by issuing fractional entitlements for upper tier crude oil, little would have changed. With such a program, the implicit subsidy to refiners for purchases of uncontrolled oil would have been preserved, and the price of crude oil to all refiners would have been equalized. However, as actually implemented, entitlements under EPCA raised the cffective price of impurted crude oil by as much as $\$ .21$ per barrel. Thus, those refiners that relied heavily upon imported oil faced a somewhat higher price for crude inputs than did those firms with access to domestic supplies. However, the likely magnitude of input price differences across refining firms appears quite small. 


\section{Chapter 3}

\section{THE EFFECTS OF PRICE REGULATIONS ON REFINERS}

Although the final goal of this analysis is to examine the effect of gasoline price controls by comparing foreign and domestic prices, the present section focusses attention upon controls on domestic refiners and temporarily ignores imports of finished petroleum products. International markets are examined at a later point. While this section of the analysis was not a part of the proposed program of research, it seemed important for two reasons. First, in order to construct a framework for comparing foreign and domestic prices it is necessary to gain an understanding of the effects that price controls would be expected to exert on domestic markets, if they are in fact effective. Second, the analysis of previous authors, reviewed above, appeared to be flawed or incomplete in certain important respects. This is particulariy true in that previous analysis has looked at industry responses as if the industry were a single firm or collection of identical firms. It is for both reasons that the analysis in this chapter was undertaken.

\subsection{U.S. Refined Product Markets: 1974}

To set the stage, recall the pattern of price regulations in existence in early 1974. By October 1973, Phase IV controls (after early modifications), had established a two-tiered pricing system for crude oil (see Chapter 1). To solve the resulting allocation problem caused by legal requirements that a homogeneous input be sold on the market at two widely different prices, EPAA based old oil allocations upon historic buyerseller relationships. The result was a substantial disparity between the 
amounts of old oil available to various refining firms. As noted earlier, refiners were allowed under Phase IV to charge their May 15, 1973 price for refined products plus any increase in the average acquisition cost of crude oil and other petroleum inputs. They were also allowed to pass through various other nonproduct costs, subject to a profit margin constraint.

In describing the domestic supply of refined products, it is assumed that each refining firm experiences rising short run marginal costs for each product produced, if factor prices are held constant. Although the overall production technology may exhibit constant returns to scale (as posited by Phelps and Smith and Roush), it is assumed here that each firm's refinery capital (e.g., plant) is fixed in the short run (or can be varied only at very high cost). The assumption of limited capacity in the short run seems particularly relevant since allowed cost pass-through formulae largely omitted capital expenditures and depreciation prior to JuTy 1976.

The price control features of Phase IV, as they constrain the individual refining firm, are expressed mathematically and diagrammatically in the same fashion as earlier used for industry level analysis. If $\bar{p}^{i}$ is the maximum price firm $i$ may charge and $P_{0}^{i}$ is its base period (May 15 , 1973) price, the price control formula, as it constrains this firm, may be written

$$
\begin{aligned}
\bar{p}^{i} & =p_{0}^{i}+\left(r_{0} x_{0}^{i}+r_{t}\left(x_{t}^{i}-x_{0}^{i}\right)\right) / x_{t}^{i}-r_{0} \\
& =p_{0}^{i}+\left(r_{t}-r_{0}\right)\left(1-x_{0}^{i} / x_{t}^{i}\right)
\end{aligned}
$$

where $r_{t}$ is the current price of uncontrolled crude oil, $r_{0}$ is the controlled price of old oil, $x_{t}^{i}$ is the firm's total crude oil input, and $x_{0}^{i}$ is its allocation of old oil. (Actually, this formula is valid only 
so long as $x_{t}^{i}>x_{0}^{i}$, i.e., in the situation where the firm refines some uncontrolled oil.) The formulae in (8) and ( $\left.8^{\prime}\right)$ ignore changes in nonproduct costs (e.g., costs associated with inputs other than crude oil and other petroleum products), as well as profit margin constraints imposed on nonproduct cost pass-throughs.

It is important to note that the "price control schedules" in (8) and ( $\left.8^{\prime}\right)$ may well be different for different firms. The sources of differences are the terms $x_{0}^{i}$ and $P_{0}^{i}$, the firm's old oil input and base price, respectively. Prior to implementation of the Entitlements Program, there were disparities in individual firms' access to price controlled old oil. Further, base prices were set at their May 1973 levels. This was a time of rapidly changing prices, both in domestic and international markets. It also coincides roughiy with the time at which Special Rule 1 (under Phase III controls) was implemented, with its differential treatment of large and small refiners (see Chapter 1). For these reasons, the base period may well have been characterized by disequilibrium, and consequent differences in the base period prices of various firms may have existed.

The relationship in (8) is plotted as $\overline{\mathrm{p}}^{i}$ in figure $5 \mathrm{~A}$. As noted, it is in fact an "average revenue constraint" for the firm; price-quantity combinations lying above the line $\overline{\mathrm{p}}$ are illegal. The term $x_{0}^{i}$ represents the amount of price controlled old oil available to the firm; following other authors, it is assumed that price controlled old oil is in fixed supply to each firm. The curve $\vec{p}^{i}$ rises at a declining rate and approaches $p_{0}^{i}+r_{t}-r_{0}$ as $x_{0}^{i} / x_{t}^{i}$ tends toward zero, i.e., as total refinery throughput increases. To describe the firm's output behavior, however, it is more useful to examine the implied "marginal revenue constraint" since this will determine the firm's output decisions at the margin. It is 
Figure 5 A

Refined Products Supply Under

Price Controls

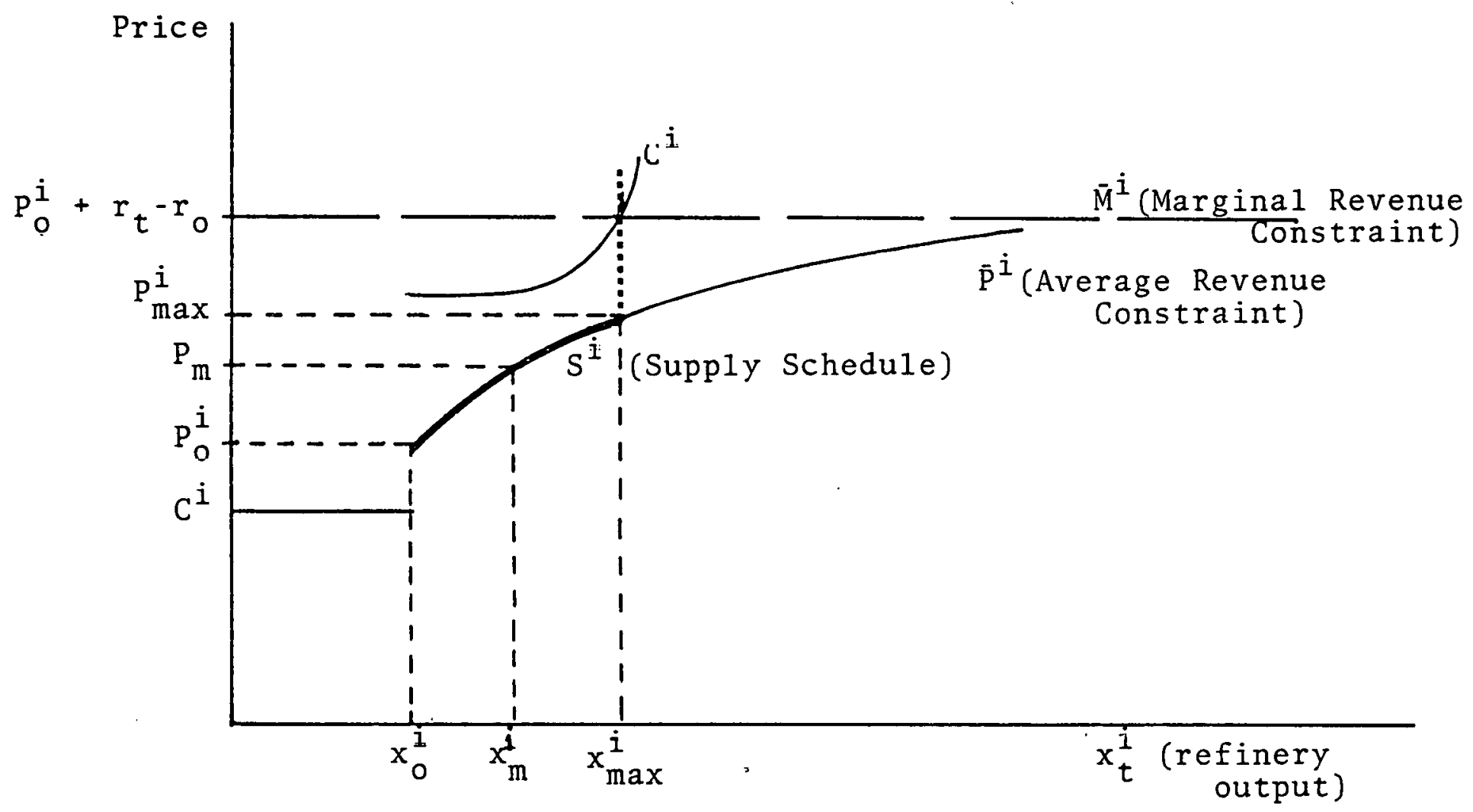


simple to show that the marginal revenue constraint associated with curve $\bar{p}^{i}$ is the dashed 1 ine in Figure $5 A$ denoted $\bar{M}^{i}$.

Since the firm is able to obtain crude oil input at two widely different prices $\left(r_{0}\right.$ and $\left.r_{t}\right)$, its marginal cost curve is discontinuous at the point $\left(x_{0}^{i}\right)$ where it switches from use of old oil to uncontrolled oil. The marginal cost curve is sketched as $C^{i}$ in Figure $5 A$ and is assumed to be relatively flat up to the point where capacity is reached. In order to represent marginal cost for a particular product on the same diagram as the price control schedule, it is necessary to assume that the inputoutput ratio is constant, (This is, of course, required only because of the limitations inherent in a two-dimensional diagram, and it is not necessary for the underlying argument.) The lower branch of this curve is shown to lie below $P_{0}^{i}$ at input level $x_{0}^{i}$ to represent the plausible situation that the firm's base period output level exceeded its old oil allocation under EPAA. This seems plausible since "old oil" represented only about $40 \%$ of total refinery input during the period in question (Phelps and Smith, Table 11, and Kalt, Table 8).

When considering the actual level of output the firm would produce, it is clear that it would never exceed $x_{\max }^{i}$, the point at which marginal cost $\left(C^{i}\right)$ intersects the maximum marginal revenue constraint $\left(\bar{M}^{i}\right)$. Further, production at this level $\left(x_{\max }^{i}\right)$ would limit the firm's price to $P_{\max }^{i}$, as is consistent with the price control schedule $\bar{P}^{i}$. However, the price $P_{\max }^{i}$ may lie above the price charged by other firms in the market. If, for example, the market price 1 ies at $P_{m}$, the firin Ilust produce at least $x_{m}^{i}$ in order to legally sell at this price. Likewise, for other market price levels below $P_{\max }^{i}$, the firm will maximize profit by producing at the level associated with the price control schedule $\bar{p}^{i}$. Thus, the firm's supply schedule (showing price-quantity combinations) is that 
portion of the curve $\bar{p}^{i}$ that lies to the left of $x_{\max }^{i}$; beyond $x_{\max }^{i}$ it may be considered vertical, as shown by the dotted line, though prices in this range are not allowed. The firm's supply schedule has been heavily shaded in Figure $5 \mathrm{~A}$.

In Figure $5 \mathrm{~A}$, the average cost curve has been deleted to avoid clutter. However, it is easily shown that the firm depicted is covering variable costs for all output levels up to $x_{\max }^{i}$ This is clear since the marginal revenue earned by the firm $\left(\bar{M}^{i}\right)$ exceeds its marginal cost $\left(C^{i}\right)$ over this region.

As noted earlier, the price constraints (curve $\bar{p}^{i}$ ) of different firms will differ if their allocations of old oil $\left(x_{0}^{i}\right)$ or their base prices $\left(P_{0}^{i}\right)$ are different. It is simple to show that two firms with identical marginal cost curves will have different supply schedules if their price constraint schedules differ. Figure $5 B$ shows the situation for a firm that has access to a relatively small amount of old oil. As drawn, the firm's marginal cost curve $\left(c^{i}\right)$ intersects the price control schedule $\bar{p}^{i}$. As before, the firm will never produce past the point where $c^{i}$ $\bar{M}^{i}$. Further, if the market price happens to at $P_{m}^{\prime}$ (or at any other level below the point where $c^{i}$ /intersects $\bar{p}^{i}$ ) the firm will produce just enough output $x^{i \text { e }}$ to allow it to charge price $P_{m}^{\prime}$. Thus, for prices below the level where $C^{1}$ intersects $\bar{p}^{i}$, the firm's supply schedule coincides with the curve $\bar{p}^{i}$. However, if the market price should be above this intersection, say at $P_{m}^{\prime \prime}$, the price control schedule is not binding. Rather, competition from other suppliers is the force limiting the price the firm charges, and marginal cost is equal to market price. At price $P_{m}^{\prime \prime}$ the firm would produce output $x^{i}{ }^{\prime}$. Thus for prices in the range where $c^{i}$ lies below $\vec{p}^{i}$, the firm's marginal cost curve is its supply schedule. The entire supply schedule has been heavily shaded in Figure 5B. An important 
Figure 5B

\section{Refined Products Supply Under}

Price Controls

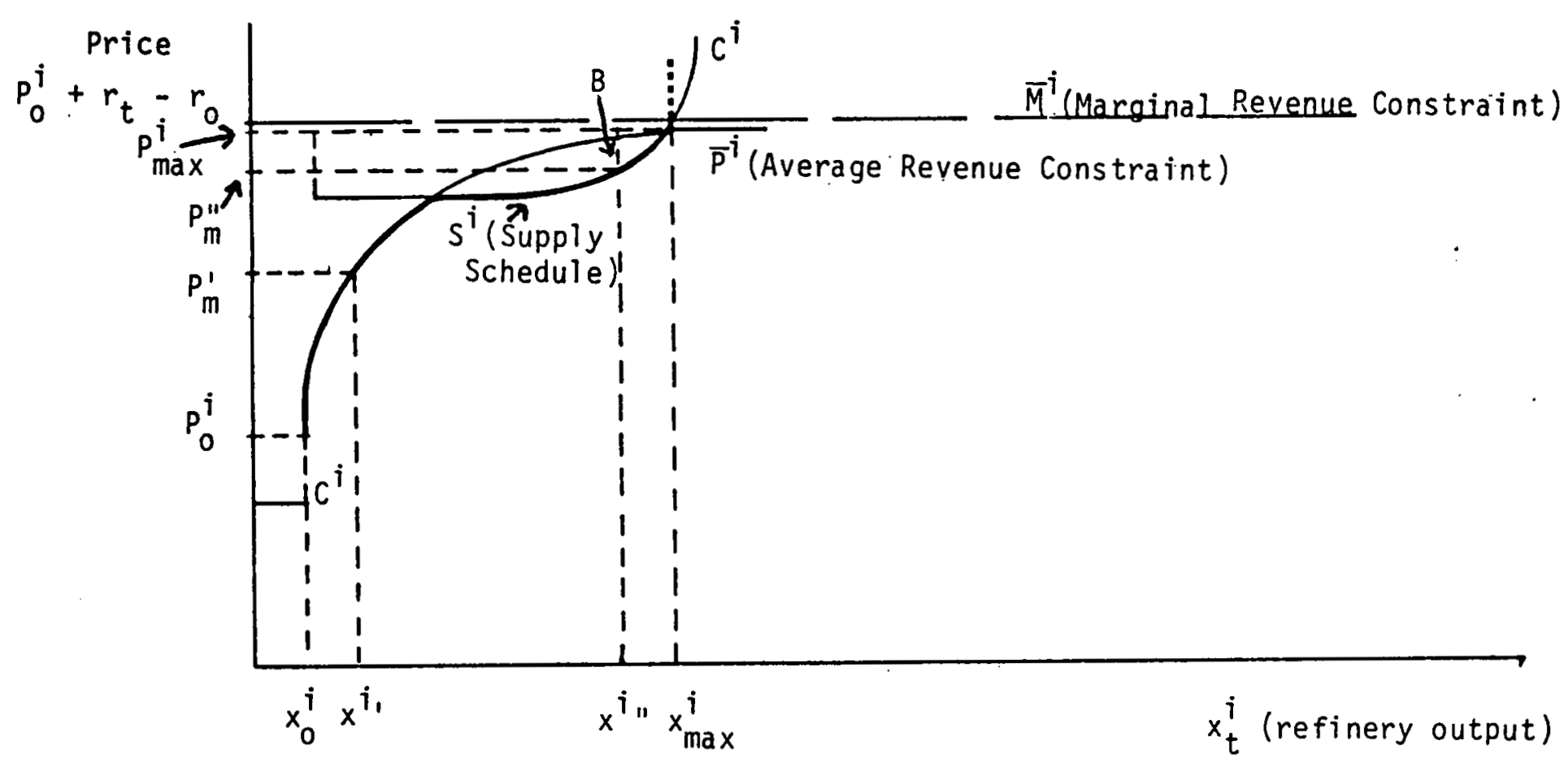


point to note here is that if market price is at a level where the marginal cost schedule $C^{i}$ lies below the price control schedule $\vec{p}^{i}$, then the firm will not be exercising all of its rights to pass cost increases through to final prices. In Figure $5 \mathrm{~B}$, the firm would be "banking costs" at a rate of $B$ per unit output, if the market price is $P_{m}^{\prime \prime}$.

To examine the effects of price controls under Phase IV regulations prior to the Entitlements Program, upon refined products allocations, it is necessary to consider the effects of these regulations upon both sides of the market. The influence of controls upon the effective supply schedules of refined products producers were just discussed. To characterize the effect of controls upon demanders, consider Figure $6^{1}$. In this diagram, the dashed line labeled $D^{j}$ represents the ordinary refined products demand curve of buyer $j$ as it would exist in the absence of controls. Suppose that the control policy results in two prices $P_{\max }^{a}$ and $P_{m}$ at which refined products may be purchased. The amount available at the lower price, $P_{\max }^{a}$, is rationed according to an explicit allocation scheme. At a price of $P_{m}$, however, the firm may purchase as much as it wishes; supplies from this source are, in effect, uncontrolled. The reason for characterizing controls in this fashion becomes apparent. helow, when supply and demand responses are brought together in the same diagram.

It is evident from Figure 6 that the total amount purchased by firm $j$ under this scheme depends upon firm $j$ 's allocation of the controlled product (that available at price $P_{\max }^{a}$ ). If the firm's allocation of controlled product is less than $x_{0}^{j}$, the quantity it demands at price $P_{m}$ is $x_{0}^{j}$ (as would be the case without controls). If, on the other hand, its allocation is above $x_{j}^{0}$, then it will purchase only its allocation of controlied product (up to a 
Figure 6

A Representative Buyer's Purchase

Pattern Under Price Controls

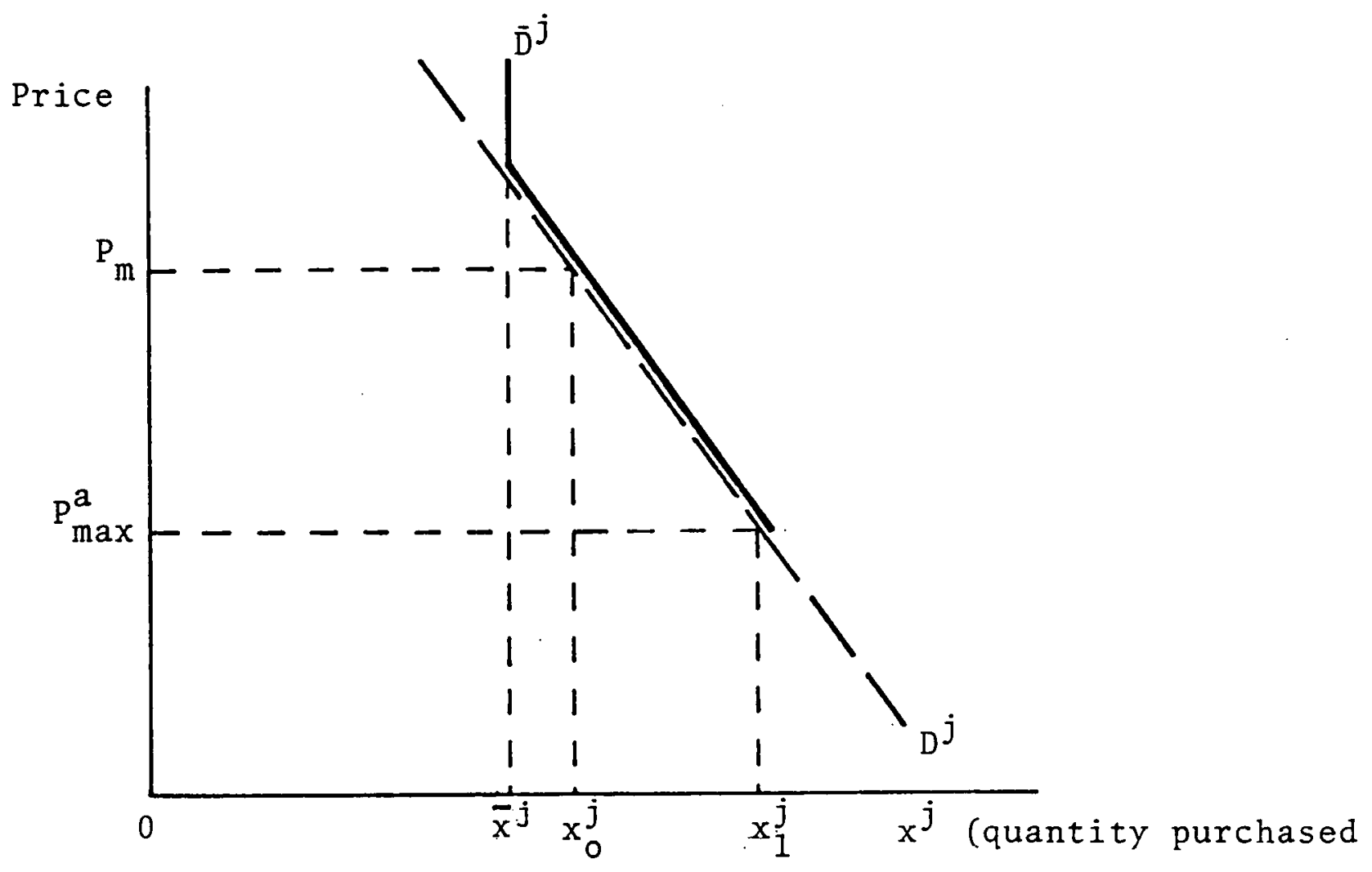


limit of $x_{1}^{j}$ ) Quantity purchased expressed as a function of the price $P_{m}$, assuming the firm is allocated $\bar{x}_{j}$ units of controlled product at a price $P_{\max }^{\mathrm{a}}$, is drawn as the solid curve laheled $\overline{\mathrm{D}}^{\mathrm{j}}$ in Figure 6 .

To obtain an aggregate effective demand schedule under price controls, the purchasing schedules $\left(\bar{D}^{j}\right)$ are horizontally summed for different firms in the industry. In Figure 7 , the aggregate effective demand schedule is drawn as curve $\bar{D}$. Recall that its shape is dependent upon the fixed price of controlled product $\left(P_{\max }^{a}\right)$ and upon the way in which the price controlled output is allocated among buyers. ${ }^{2}$ The ordinary industry demand schedule (as it would exist in the absence of controls) is drawn as the dashed line $D$ in. Figure 7.

To characterize supply responses of refined product producers, consider a simplified industry made up of two sets of identical refining firms ( $a$ and $b$ ). Within each set, firms are identical both with respect to marginal cost and price control schedules. However, firms in different groups have different supply schedules, due either to differences in costs or price control schedules. For simplicity, the two different firms shown in Figures $5 A$ and $5 B$ are taken to be representative of firms in the two groups ( $a$ and $b$ ). In Figure 7 , the aggregate marginal cost schedules for the two types of firms (in

Figures $5 \mathrm{~A}$ and $5 \mathrm{~B}$ ) have been horizontally summed to give an aggregate marginal cost schedule, $C^{\top}$. Likewise, the supply schedules have been horizontally summed to yield an industry supply schedule $S^{\top}$ (heavily shaded). The vertical dimension of the diagram has been distorted somewhat to provide easier visual inspection. 
Figure 7

Industry Supply of Refined Products

Under Price Controls

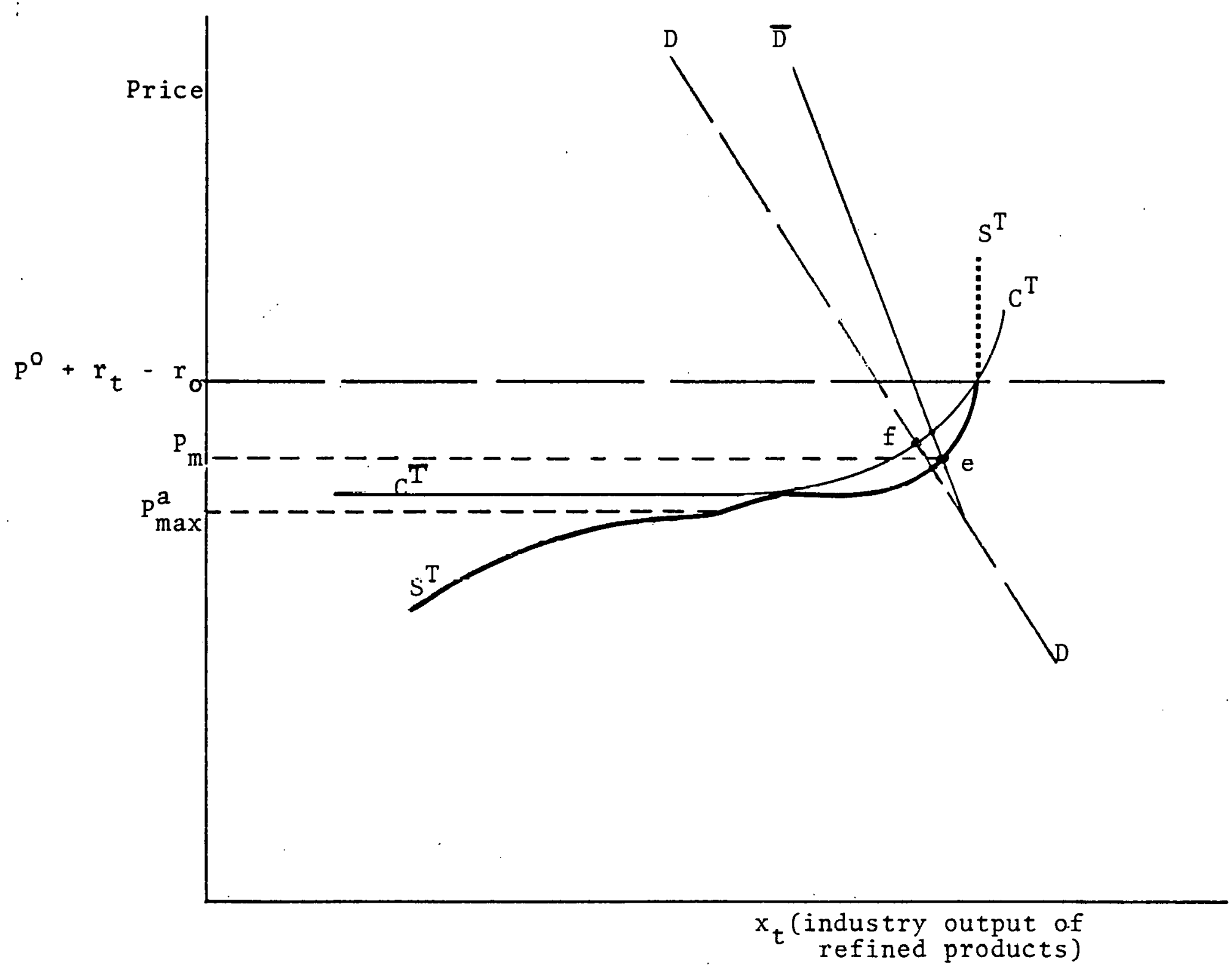


Point $e$ in Figure 7 represents an equilibrium in the following sense: at price $P_{m}$, the quantity that purchasers (e.g., refined product wholesalers) are willing to buy is just equial to the quantity that producers are willing, and legally able, to sell. This solution is, however, characterized by a peculiar feature ; the output of firms in category a is selling at a price $\left(P_{\max }^{a}\right)$ which is less than $P_{m}$. In equilibrium, there is excess demand for the price controlled output of firms in group a, but those not able to obtain output from a are still able to satisfy 
their demands at the higher price $P_{m}$. Thus, there is no shortage in the classical sense because there is a price at which demanders are able to buy as much refined product as they desire.

In the situation depicted in Figure 7 , some firms are constrained by price controls (type a) while others are not. Clearly, this is not the only situation possible. Depending upon the total volume of old oil produced (relative to total crude oil output), and the distribution of old oil among firms, it is certainly possible that no firms were effectively constrained, or that they all were. Evidence supplied by Kalt and by Phelps and Smith indicates that, for the refining industry as a whole, banked costs were positive. Thus, it is safe to assume that there were some firms in the unconstrained category (type b) throughout the period. However, data on banked costs for individual firms (presented later) indicates that a significant portion of industry output was produced by firms that were price constrained, at least for several months during the control period. Thus, the situation in Figure 7, with some firms constrained and others not, seems an appropriate representation.

Consider some of the observable attributes of the situation in Figure 7. First, output is higher and marginal price $\left(P_{m}\right)$ is lower than would be the case without price controls (represented by point $f$ in Figure 7 ). (Hereafter, marginal price, $P_{m}$ in Figure 7 , denotes the highest price observed in the market.) Considering price differences between the two classes of producers, "average price" (falling somewhere between $P_{\max }^{a}$ and $P_{m}$ ) is considerably lower than the uncontrolled equilibrium price. Second, there is price dispersion, i.e., products of different firms are being traded at different prices $\left(P_{\max }^{a}\right.$ and $\left.P_{m}\right)$. Third, firms in category b are not exercising some of their allowed price increases; each firm in this class is reporting banked costs equal to B (see Figure 5B) per unit output. Firms in class a, on the other hand, have no banked costs. Empirical evidence on these hypotheses is presented later. 
These primary effects may well give rise to secondary phenomena that cannot be read directly from the diagram. These indirect effects result from the predicted pattern of price dispersion. Since a's output is priced below that of $b$, one would expect buyers to compete for rights to the price controlled product. One outcome might be the occurrence of "tie-in sales," agreements to purchase a non-price controlled product at an inflated price in order to obtain some of the controlled item. Barring such arrangements, one would expect that the excess demand for a's output would induce type a firms to lower the quality of the $i$ tem or related services offered. Perhaps the easiest dimensions in which to vary quality are credit allowances, promptness of delivery, duration of purchase contract, volume of purchase contract, etc., rather than any physical attributes of the product itself. Unless such devices as tie-in sales and quality differences are able to fully equalize the real price of the two classes of products, one might expect those who are unable to obtain the price controlled output to voice demands for an explicit allocation mechanism to eliminate seemingly arbitrary or discriminatory market allocation practices. In this regard, it is interesting to note that the FEA did implement refined product allocation regulations throughout this period. For a summary of these regulations, see Roush (1976).

It is of interest to note what would happen if the demand curve(D) in Figure 7 intersected $S^{\top}$ in the vertical (dotted) region. In this case, a true shortage would exist; further no firms in the industry would have banked costs. Price dispersion would, however, remain. Al ternatively, if the demand curve cut $S^{\top}$ at a point where all firms are price constrained (left of the point where $S^{\top}$ and $C^{\top}$ are shown to touch), then there would be no price dispersion and no banked costs. Evidence presented 
later indicates that price dispersion was prevalent during this period and that some firms had positive banked costs while others had none. Thus the configuration shown in Figure 7 seems an appropriate representation.

It should be mentioned that as initially implemented, cost passthroughs for crude oil price increases, were allowed only after a one month delay. In a period of rapidly rising crude oil prices (e.g., late 1973 and early 1974) this would have caused refining firms' marginal cost schedules to shift up more rapidly than their price control schedules. Hence there would be a greater tendency for price ceilings to be binding in such circumstances,

The foregoing analysis ignored one set of considerations that was emphasized by Phelps and Smith, the effect of the crude oil price increases upon the prices of other refinery inputs. Recall from equation (4) that reduction in other input prices will tend to make the price control formula less binding. Phelps and Smith argue that, in general equilibrium, prices of factors not included in the cost pass-through provisions, will tend to fall. This result depends upon plausible assumptions regarding possibilities for substitution and upon the notion that the supply of the omitted factor is upward sloping to the industry. As they point out, however, "in the refinery industry, the excluded factor is capital" (Phelps and Smith, p. 20). From our viewpoint, it seems likely that the supply of capital (and other "nonproduct" inputs) is highly elastic to the refining industry and that any general effect that crude oil price increases have upon the market rental price of capital will be of a small magnitude. Hence, this set of considerations was not highlighted in the preceding analysis.

In addition to the price control formulae discussed above, refiners were subject to profit margin constraints that limited pass-throughs of 
nonproduct costs. Phelps and Smith, the only previous authors to explicitly analyze this aspect of policy, concluded that profit margin constraints were ineffective. Their argument follows from the observation that crude oil cost increases and subsequent price increases would tend to raise both costs and revenues by similar amounts. Hence, the firm's profit margin, (net revenue divided by total sales) would tend to automatically fall below historic levels. In such circumstances, there would exist considerable "slack" in the constraint which could be used to pass through nonproduct cost increases. Although we have no evidence on this question, the argument presented seems convincing. It should be noted, however, that prior to mid-1976, limitations on the types of nonproduct costs that could be passed through were very restrictive.

\subsection{Regulation of the Refining Industry After 1974}

The rather detailed discussion and analysis of regulations effective in 1974 presented in Section 3.1 facilitates a more rapid treatment of control policy instituted after 1974. This is true since many of the general regulatory provisions effective in 1974, or at least their basic concepts, remained in force throughout 1975-1977. The more significant policy changes include the Entitlements Program (adopted in Novemher 1974 and implemented one month later), increased tariffs on crude oil and finished product imports (in effect throughout 1975), and the enactment of the Energy Policy and Conservation Act adopted in late 1975 (and implemented early in 1976).

\subsubsection{The Entitlements Program}

Under the allocation formula initially instituted with EPAA, access to price controlled "old ofl" varied substantially among refiners and gave rise to profit (rent) differentials in the refining industry (see 
Kalt, pp. 4-5, 15, 16; Phelps and Smith, pp. 47-49). The Entitlements Program revised the mechanism whereby individual refiners were allocated rights to purchase price controlled oil, and tended to equalize access across firms. Briefly stated, this is achieved by guaranteeing any firm that refines, say, one million barrels of oil that it will be able to purchase some fraction (k) of this oil at the controlled price. The balance $(1-k)$ must be purchased at the uncontrolled crude oil price. In order for this policy to be feasible, it is of course necessary that the fraction $k$ guaranteed to each firm be equal to the ratio of old oil to total crude oil consumption by domestic refining firms. The policy was implemented by issuing entitlements (on a monthly basis) to purchase old oil; the number of entitlements issued was equal to the volume of old oil produced. These entitlements were distributed to individual refiners in proportion to their total volume of crude oil input; using the above notation, each refiner received $k$ times its total volume of crude oil refined. (There were exceptions to this rule, for small refiners, as noted below.) Entitiements could be transferred among firms at a price set approximately equal to the price differential between uncontrolled and controlled oil, and, in order to refine a barrel of old oil, a refiner had to hold an entitlement. Thus, those firms that had access to relatively large quantities of old oil (a fraction of total oil input larger than $k$ ) were required to purchase entitlements from old oil deficient firms. Likewise, those with little or no access to old oil could sell entitlements to other refiners. As explained by Cox and Wright (1978), this policy tended to equalize the net price of all oil used (controlled and uncontrolled) at a price equal to the weighted average of controlled and uncontrolled prices. According to estimates provided by Kalt, the effective subsidy on marginal crude oil supplies amounted to 
$\$ 2.11-\$ 3.42$ during the period from January 1975 to December $1976 .^{3}$

Since the price of old oil $\left(r_{0}\right)$ is controlled, the quantity of old oil supplied to the refining industry $\left(X_{0}\right)$ is essentially fixed. Uncontrolled oil, however, is in very elastic supply, particularly from foreign sources. As an approximation, one might consider the supply of $X_{u}$ (uncontrolled oil) to be infinitely elastic (in the relevant range) at the price $r_{w}$. With these simplifications, it is possible to plot the relationship between total crude oil supplies to the U.S., and the effective price of crude oil under the Entitlements Program. This is shown as curve $S_{E}$ in Figure 8. In the absence of any control policy, the supply of crude oil to the domestic refining industry would be perfectly elastic in the relevant range, at the uncontrolled world price $r_{w}$. Thus, the Entitlements Program increased the effective supply (at each price) to the domestic refining industry, as compared to a situation without any controls.

Although one can rather easily postulate the influence of entitlements on refined products supply, as compared to a "no regulation" policy, it is more difficult to analyze the effects of a switch from the 1974 allocation scheme to that embodied in the Entitlements Program. This difficulty follows from the fact that the policy change had two sorts of effects upon the domestic refining industry's supply schedule. First, the Entitlements Program reduced the cost of marginal barrels of crude oil from its uncontrolled 1974 level $\left(r_{w}\right)$ to a weighted average of controlled and uncontrolled prices $\left(r_{e}\right)$. This marginal price reduction lowered the marginal cost of refined products and, by itself, would have tended to reduce product prices (see Figure 1). However, this first effect was at least partially offset by a second influence. Under 1974 regulations, the typical refining firm faced a two-tier price schedule for crude oil. Given this two-tier schedule and provisions for cost 
Figure 8

Crude 0il Supply Under Entitlements

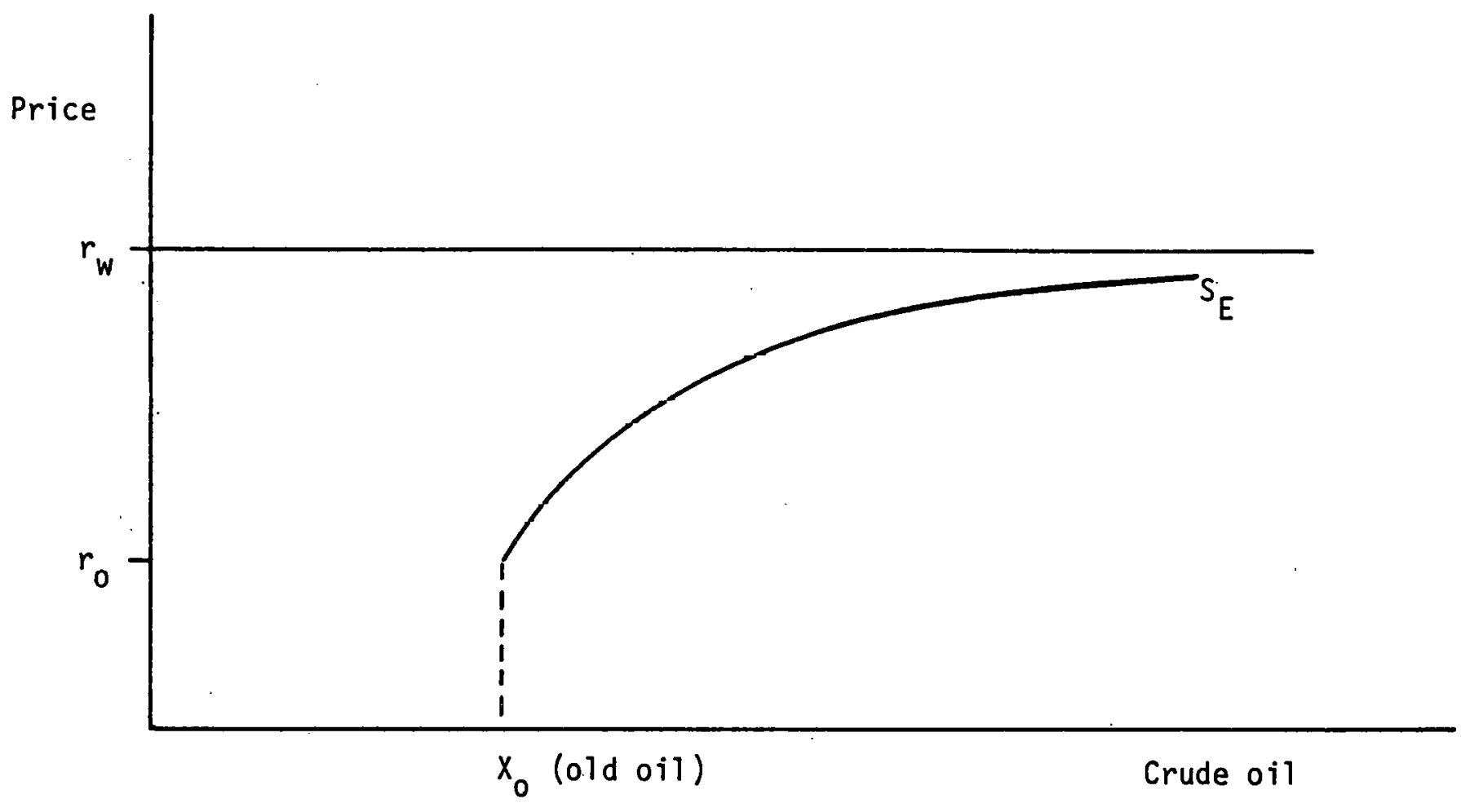

Figure 9

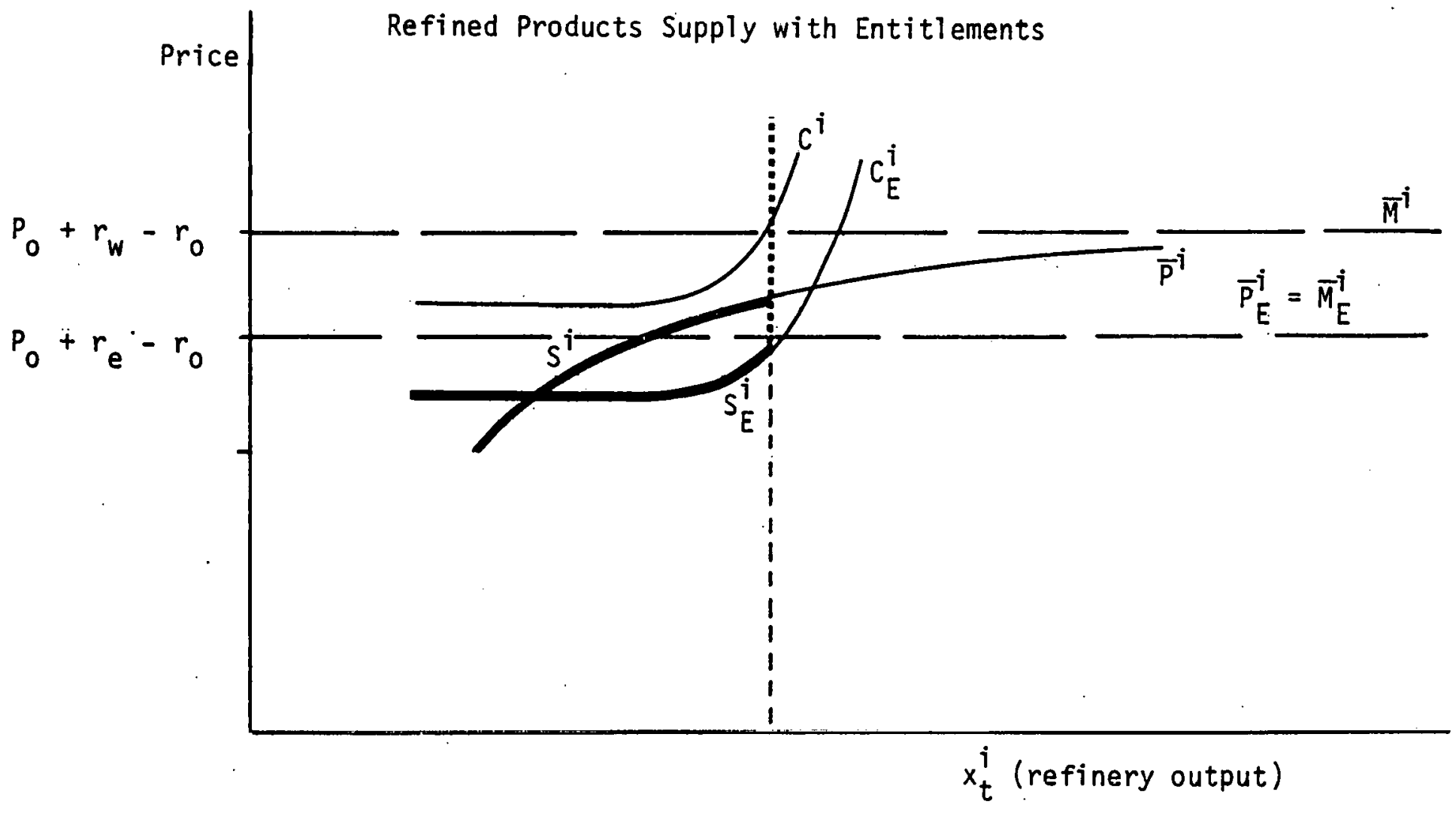


pass-throughs, maximum marginal revenue exceeded the price ceiling schedule. For some refiners (those constrained by price controls) there was an incentive to expand production and sell at prices that were less than marginal cost (see Figure 5A). With entitlements, a single effective crude oil price emerged, and this incentive disappeared.

These two effects are shown in Figure 9 for a firm that was constrained by 1974 price control policy. The firm's 1974 marginal cost and supply curve are shown as $C^{i}$ and $S^{i}$ respectively. The 1974 situation shown corresponds to that drawn in Figure 5. With enactment of the Entitlements Program, the marginal price of oil was lowered, and hence the marginal cost of refined output was reduced to $C_{E}^{i}$. Further, since the firm now pays the same effective price for all crude oil purchased, the passthrough provision does not cause the firm's ceiling price to rise as crude $0 i 1$ inputs are increased. With entitlements, the ceiling price is fixed at $P_{0}^{i}+r_{e}-r_{0}$ regardless of the quantity of crude oil purchased. Hence, the firm's supply curve $S_{E}^{i}$ becomes that portion of marginal cost $\left(C_{E}^{i}\right)$ that lies below the ceiling price.

For the above reasons, it is not possible to make general statements regarding the effect of introducing the Entitlements Program upon refined product prices or output levels. However, it appears very likely that any price dispersion experienced under 1974 regulations would have been dramatically reduced. This is so, because the price ceiling schedules under 1974 regulations (the average revenue constraints) were replaced by a simple price ceiling $\left(P_{0}^{i}+r_{e}-r_{0}\right)$ when the Entitlements Program was introduced. Some price dispersion may have continued to exist under the Entitlements Program, however, if individual base prices $\left(P_{0}^{i}\right)$ were different for different firms. An additional source of possible celling 
price differentials existed because of preferential treatment extended to small refiners under provisions of the Entitlements Program. (See Roush, pp. 49,50 for further discussion.) Under the "Small Refiners Bias," refiners processing less than 175,000 barrels of crude oil per day were allotted entitlements in excess of their pro rata share of national crude oil input. By reducing the effective price of crude oil to small refiners, this policy lowered the marginal cost of output for such firms. At the same time, it reduced the ceiling price for small producers, since payments for entitlements were allowed to pass through into the ceiling price of the final product. Thus, an additional source of price dispersion under the Entitlements Program could have arisen from the favorable treatment of small refiners.

\subsubsection{The Crude 0il Tariff of 1975}

Effective February 1, 1975, shortly after adoption of the Entitlements Program, a tariff of $\$ 1.00$ per barrel was introduced on crude oil imported into the United States. This import fee was in addition to the license fee, imposed initially at 10.5 cents per barrel, in May 1973. The license fee was gradually increased and on February 1, 1975 it amounted to 21 cents per barre1. The tariff was raised to $\$ 2.00$ per barrel effective June 1,1975. The two dollar tariff remained in effect until January 7,1976 , when it was discontinued with enactment of EPCA.

The expected effect of such a tariff would be to raise the price of uncontrolled oil by approximately the amount of the tariff (given that imported crude oil supplies to the U.S. are highly elastic), to increase the quantity of uncontrolled domestic crude oil supplied, and to reduce foreign imports. 4 The predicted effect of the tariff upon refined product markets is the same as would be expected from a simple rise in the price of uncontrolled crude oil. An increase in the effective price of crude 
oil would raise the marginal cost of refined products, and would increase the ceiling price for all firms in the refining industry. Consequently, a rise in final product prices would be expected. Coincident with the crude oil tariff, duties were placed upon imports of finished petroleum products. The effect of this policy upon product imports and foreign and domestic prices is analyzed in the next chapter.

\subsubsection{The Energy Policy and Conservation Act}

The Energy Policy and Conservation Act, adopted in January 1976, made several changes in the pricing regulations on domestically produced crude oil and (as noted in Chapter 1) created two categories of price controlled crude oil. In order to administer the Entitlements Program under what was essentially a three-tiered crude oil pricing system, it was necessary to define fractional entitlements for the new category of upper tier oil. These were distributed among firms in a similar fashion as before, and thus effectively set the domestic crude oil price at the weighted average of controlled and uncontrolled prices.

Both the removal of the crude oil tariff, and the adoption of new crude oil price controls under EPCA, would be expected to lower the average price of crude oil in the U.S. Figures reported in Kalt (Table 4) indicate that the average crude price in the United States did fall by about 60 cents per barrel in late 1975 and early 1976. This average price reduction would be expected to lower the marginal cost of refined products as well as allowed price ceilings. One final aspect of EPCA should be noted. As Cox and Wright (1978) point out, the Entitlements Program under EPCA was implemented in such a fashion that it gave a $\$ .21 / b b$ preference to domestically produced oil over foreign imports. In other words, the formula for allocating entitlements (including fractional entitlements 
for upper tier oil) effectively set the price of lower and upper tier oil below the price of uncontrolled oil, and uncontrolled oil was largely supplied from abroad (see Cox and Wright, p. 6). Using the same reasoning employed in the case of the "small refiners bias," this reduced the marginal cost of refined products for those firms that had initial access to lower and upper tier oil, and lowered their ceiling prices as well. Though the $21 \$ / b b l$ figure is rather small, it nonetheless provides an additional source of possible price differences among firms.

\subsection{Price Controls in Retail Markets}

The historic development of retail price controls was traced in Chapter 1. As of September 1973, retail sellers of gasoline faced a ceiling price equal to the average cost they paid for gasoline on August 31,1973 , plus their January 1973 mark-up. During the next few months, retail price ceiling formulae were adjusted to allow retailers to pass along any increases in the price they paid for gasoline purchased from refiners and wholesalers. By the beginning of 1974, retailers were allowed to raise prices over May 15, 1973 levels to reflect increases in the costs of petroleum products purchased from refiners and wholesalers. Early in 1974, additional retail price increases of $3 \$-4 \$$ per gallon, to allow for increase in nonproduct costs, were permitted. Throughout this period, product cost increases were allowed to pass through to retail prices only after a one month delay. In a period of rapidly rising input prices, the resulting lags in retail price hikes were allegedly responsible for "substantial gaps between available supply and quantities demanded at posted prices" (Phelps and Smith, p. 7).

The effect of retail price controls upon retail markets depends crucially upon whether or not price regulations imposed on upstream 
refining activities were binding. If refinery price controls were binding, then the scenario sketched in Sections 3.1 and 3.2 , with price dispersion and general price levels below true marginal cost would describe conditions in the input market. As noted, true excess demand for the output of some (price constrained) refiners would have necessitated a form of non-price allocation. Under actual refined product allocation rules, refined product sellers were obliged to supply certain priority users (defense and agricultural bulk purchasers) and to supply other purchasers with historic amounts purchased by them in 1972 (on a monthby month basis). If retailer $A$ had an historic contract with a refiner who was necessarily constrained to sell at a low price (because his allocation of old oil was large relative to refining capacity), then $A$ would obtain low cost inputs. If the allowed retail mark up was binding on this retailer, then he would be constrained to charge a price lower than that of a retailer who faced high product costs. In this fashion, price differentials at the refinery level may have passed through to retail markets.

If retail markets were constrained and price differentials existed, there would have been excess demand for the products of those retailers forced to sell at a low price. Such excess demand need not result in noticeable queues at retail establishments, however, since the consumer has the option to move to a somewhat higher priced seller if supplies are unavailable from the low priced source. There would also. be a tendency to alter levels of service quality toward a siluation where quality adjusted prices are equal. In this case, retailers with access to low cost products would be expected to cut back on such costly related items as "full service" (e.g., pumping gasoline, window washing), credit, twentyfour hour service, etc. 
At least one factor would tend to reduce possible price differentials at the retail level as compared to wholesale markets. If the typical retailer obtained refined products from twc or more different sources at different prices, then the allowed retail price would be a weighted average of high and low input prices since average acquisition costs were used in computing retail price limits. This is really symmetric to the analysis of refinery markets, where average acquisition costs for crude oil formed the basis for allowed refined product prices.

The above discussion was predicated on the hypothesis that Phasc IV controls were binding at the refinery level. If however, they were not effective, then the picture in the retail market would be very different. In the absence of binding controls on refiners, all resellers and retailers would face a common price (allowing for transportation differentials, etc.); hence a source of distortion in retail markets (input price differentials) would not have been present. In this case, retail mark up constraints are of primary importance. It is common to equate the presence of price controls with observable shortages and queues. However, with retail refined product price controls there would have been a strong tendency to reduce service levels (as discussed earlier) in the presence of effective mark up constraints. With such behavior, price controls could have been effective without observable queues or shortages.

\subsection{Empirical Evidence}

Previous studies (Kalt and Phelps and Smith) have argued that the presence of positive banked costs in the refining industry indicate that price controls, as implemented since early 1974, have not been binding. However, this conclusion followed from an examination of industry aggregates rather than data on individual firms. The foregoing discussion 
pointed out that individual firms may be price constrained, even if industry banked costs are positive, i.e., the distribution of banked costs among firms may be very uneven, and some firms may be exploiting all allowed price increases.

Evidence on the distribution of banked costs for motor gasoline in various firms was examined to shed light on this possibility. Proprietary data on banked cost levels for 31 individual refining firms were obtained from FEA (FEO-96 Report: Bank T, F.E.A. Office of Data Services). Individual refining firms were considered to be price constrained if their reported level of available cost pass throughs for gasoline that were not taken (i.e., banked costs) were zero or negative in a given month. In this fashion, months in which price controls were binding for particular firms were identified. To provide evidence on the fraction of domestic gasoline production that was price constrained in various months, the 31 firms in the sample were divided into three groups. These groups correspond to classes of:

large integrated refiners;

large independent refiners; and small refiners;

as defined in FEA publication FEA/B-75/616 (Petroleum Market Shares). The sample of firms included 14 of the 16 firms classified as "large integrated refiners" in that publication, 5 out of 7 "large independents," and 12 small refiners. Information on banked costs for the remainder of firms in these categories was not available.

In the same publication, gasoline market shares are published for the three different classes of firms. In 1974, large integrated firms supplied $74.8 \%$ of domestic gasoline sales, large independents accounted for $7.6 \%$ and small 
refiners made up $17.7 \%$ of the market. ${ }^{5}$ Based upon these figures, and the number of firms in our sample assigned to each category, "average" market shares for individual firms in each category were computed. These average market shares were then applied to the banked cost data to obtain estimates of the percentages of domestic gasoline sales that were price constrained in each month from November 1973 through December 1977. These figures are reported in Table 3.1 .6

The first three columns in Table 3.1 show the percentage of firms in each of the three categories that experienced zero or negative banked costs in a given month. In column four, the market share estimates have been applied to the data in the first three columns. From these figures, it appears that some firms had zero banks during all months examined except two (November 1976 and February 1977). The share of the market that was apparently constrained is quite large early in 1974, as would be expected from the rapid crude oil price increases that occurred at that time and the one month lags in allowed cost pass throughs. Price constraints also appear to be significant from mid.1975 through early 1976 , and again in mid to late 1977. The apparent ineffectiveness of price controls in mid 1976 (and continuing on through early 1977) may have resulted from changes in cost pass through provisions adopted at that time. These changes made more generous allowances for pass throughs of such nonproduct costs as state and local tax increases, depreciation of refinery capital and pollution control equipment, maintenance and labor costs: At the same time, there was a change in the formula used to compute allowed price increases; the so-called $R$ and $V$ factors -- (see Federal Register, June 30,1976$)$.

It is quite possible that the figures in Table 3.1 actually understate the degree to which controls were binding. As noted in Chapter 1, after 
Table 3.1

Percent of Firms with Zero or Negative Banked Costs, and Their

Estimated Share of Domestic Gasoline Production

$\begin{array}{ccccc} & \text { PERCENT } & \text { PERCENT } & \text { PERCENT } & \text { ESTIMATEO } \\ \text { DATE } & \text { SMALL } & \text { LARGE } & \text { LARGE } & \text { TOTAL } \\ & \text { INDEPENDENTS } & \text { INDEPENDENTS } & \text { INTEGERATED MARKET SHARE }\end{array}$

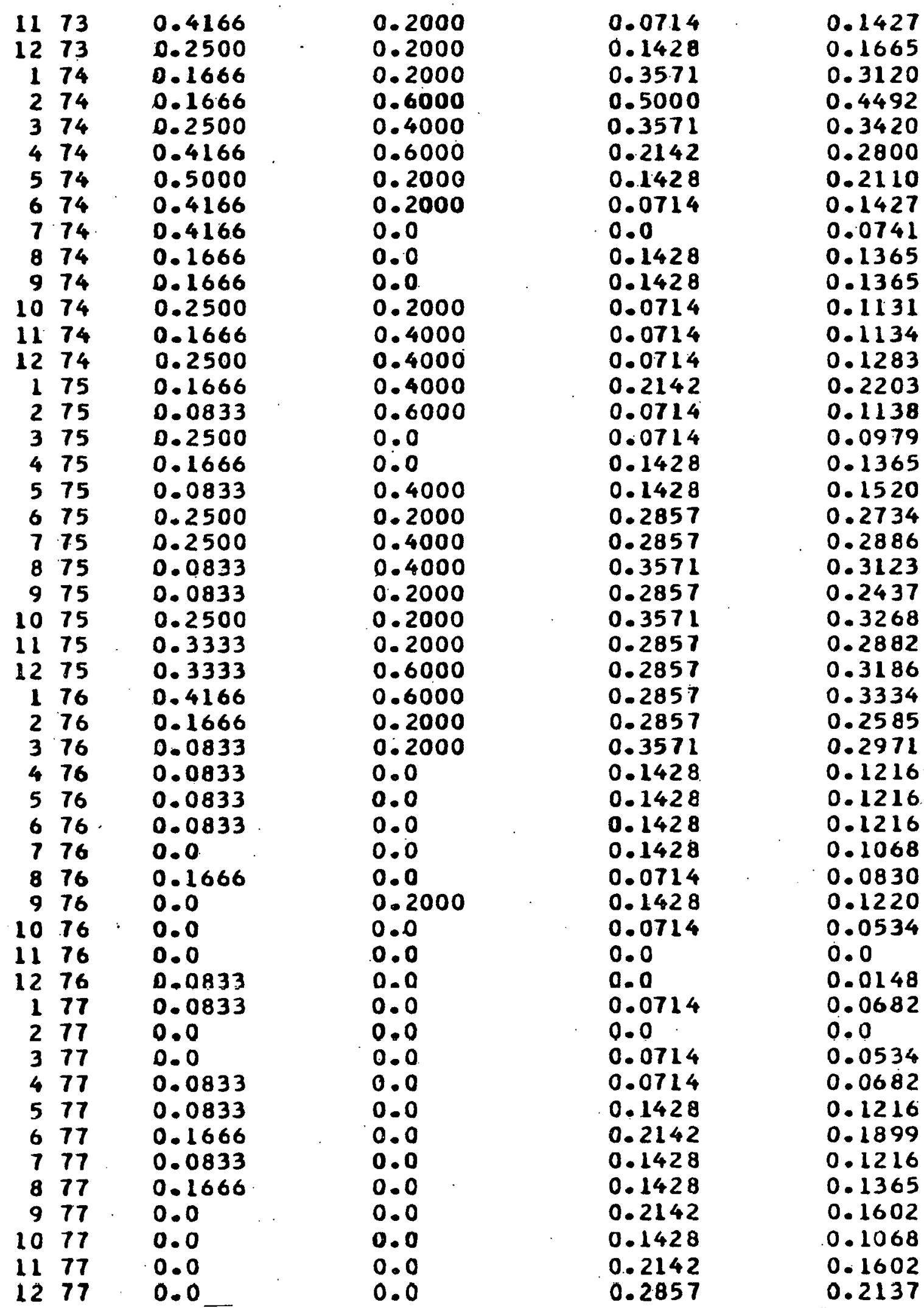


January 1975 there were 1 imitations on how rapidly firms could recoup accumulated banked costs. Thus, some firms with positive banks may have been constrained. Further, some firms may have consciously attempted to maintain banked costs above some positive level, to provide a margin for error and miscalculation in pricing policies.

The second topic on which empirical evidence is presented in this chapter regards hypothesized price dispersion induced by cost pass-through provisions in price control regulations. To address this question, monthly wholesale spot prices for gasoline were obtained for four regions in the U.S. Data were obtained on high and low quotations from a sample of refining firms. For some periods, particularly prior to 1973, high and low quotations were not reported and only an average quotation could be obtained.

Table 3.2 reports average prices as well as average monthly price spreads (high minus low price quotation) for four different periods. Period 1 is the period from January 1968 to August 1971, and thus is prior to the institution of general price controls. Period 1 was included as a control, against which prices in later periods could be compared. Period 2 covers the price control period prior to May 1973, the base period for allowed price increases under Phase IV controls. Period 3 goes from May 1973 through December 1974. This corresponds to the preentitlements era of Phase IV controls. Finally, Period 4 extends from January 1975 to December 1977 (post-entitlements).

The rapid rise of wholesale gasoline prices during the ten-year period covered in Table 3.2 is evident. Of greater interest, however, is the pattern of price dispersion displayed in column 1. For all four regions shown, little or no price dispersion was reported prior to Period 3 . The dramatic increase in reported price spreads during Period 3 (Phase IV, 
Table 3.2

Gasoline Price Dispersion Under Various

Price Control Policies

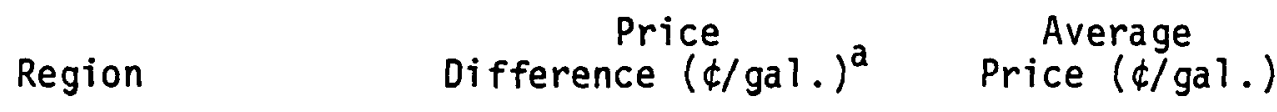

(2)

Ratio

(1)

\begin{tabular}{ll|ccc}
\hline California: & Period 1 & N.A. & 11.8313 & N.A. \\
& Period 2 & $.2079^{\star}$ & 12.4787 & .0167 \\
& Period 3 & 5.1571 & 21.9999 & .2344 \\
& Period 4 & 2.7000 & 34.9823 & .0772 \\
\hline Chicago: & Period 1 & $.2500^{\star}$ & 12.3923 & .0202 \\
& Period 2 & N.A. & 13.2625 & N.A. \\
& Period 3 & $5.2500^{\star}$ & 23.1726 & .2265 \\
& Period 4 & 2.3122 & 35.3181 & .0654 \\
\hline Gulf Coast: & Period 1 & .2349 & 10.5970 & .0222 \\
& Period 2 & .0500 & 11.4875 & .0044 \\
& Period 3 & 4.0500 & 21.4916 & .1884 \\
& Period 4 & N.A. & N.A. & N.A. \\
\hline Mid Continent: & Period 1 & $.2949 *$ & 11.7615 & .0278 \\
& Period 2 & N.A. & 12.0750 & N.A. \\
& Period 3 & $3.2917^{\star}$ & 21.3154 & .1544 \\
& Period 4 & 1.7959 & 34.2087 & .0052 \\
\hline
\end{tabular}

Source: $\underline{\text { 0il }}$ and Gas Journal

Note: Period 1 is pre-price control, $1 / 68-7 / 71$; Period 2 covers Phases I and II, 8/71-4/73; Period 3 is Phases III and IV, pre-Entitlements Program, $5 / 73-12 / 74$; Period 4 is post-Entitlements, $1 / 75-12 / 77$.

a. Price differences are differences between high and low price quotations in the middle of each month.

* Due to changes in reporting practices and a failure to report high and low prices in some periods, these entries represent average price differences for only a portion of the period in question. 
pre entitlements) is evident for all four regions. As argued earlier in this chapter, this is the period in which the greatest degree of price dispersion would be expected. With the adoption of the Entitlements Program, average crude oil prices were more nearly equalized across firms. Consequently, a reduction in the degree of price dispersion was anticipated. As Table 3.2 shows, these expectations were realized in all four regions.

The significance of these changes in price spreads rrom period to period was examined by comparing the difference in mean price spreads in different periods to the standard deviations of these differences. The results of this analysis of variance indicated that for each of the four regions considered, the mean level of price dispersion experienced in Period 3 was significantly greater (at $5 \%$ ) than mean price dispersion in either Periods 1 or 2. Likewise, for the three regions in which comparisons were possible, price dispersion was significantly reduced in Period 4 (compared to Period 3).

Some of the dispersion in domestic retail prices may well have been due to the crude oil embargo and OPEC cartelization, and the effects they had upon world petroleum products markets. These unsettling events shifted supply schedules for refined products rather violently, and during the adjustment period some price dispersion would be expected to arise naturally as the market searched for a new equilibrium. However, as noted in the next chapter, the level of price dispersion in foreign gasoline markets generally exceeded U.S. dispersion prior to May 1973, but was consistently lower than U.S. price dispersion levels after that time (at least until mid 1976).

On balance, this evidence on prices and banked costs indicates that the effectiveness of U.S. gasoline price controls should not be 
surmarily dismissed. The absence of queues at gasoline stations and the observation that some firms maintained unexercised price increase allowances cannot be taken as conclusive evidence. At the same time, however, the foregoing analys is has not provided estimates of the magnitude of any constraining effect that occurred. This question is pursued in the following two chapters. Further, results presented in Table 3.2 are important for ensuing empirical analysis since they indicate that gasoline price dispersion is not a mere data reporting anomaly, but is directly related to the structure of U.S. controls and should be taken into account in any study of U.S. gasoline prices. 


\section{Chapter 4}

\section{FOREIGN-DOMESTIC GASOLINE PRICE COMPARISONS} BASED UPON PRODUCTS MOVING IN TRADE

Any analysis of the effect of price control policy upon U.S. gasoline prices must consider the influence of such policy upon international trade. Both prior to the imposition of cuntrols, and under price controls as instituted up to the present, the U.S. has imported motor gasoline from abrnad. Table 4.1 summarizes relevant aspccts of this trade. ' Imports were restricted prior to early 1973, but rose dramatically when mandatory quotas were removed in April 1973, even though the domestic price of gasoline was nominally controlled. To some (e.g., Phelps and Smith (1976)) the presence of trade indicates that domestic controls are ineffective. Others, however, (e.g., Kalt (1977) and Roush (1976)) have provided partial evidence that imported foreign gasoline (delivered to domestic markets) has, at times, been more expensive than domestic gasoline and for this reason have dismissed the imports argument. However, no explanation has been offered for the observation that imports occurred throughout the period. In general, the relationship between foreign and domestic prices and U.S. price control policy has not been analyzed empirically. This relationship is the topic of this chapter.

\subsection{International Trade and Foreign-Domestic Price Relationships}

The basic premise underlying any comparison of prices in two or more markets is that, in the absence of impediments to competition among buyers and sellers, the price of a given item will be the same in 
Table 4.1

U.S. IMPORTS OF MOTOR GASOLINE

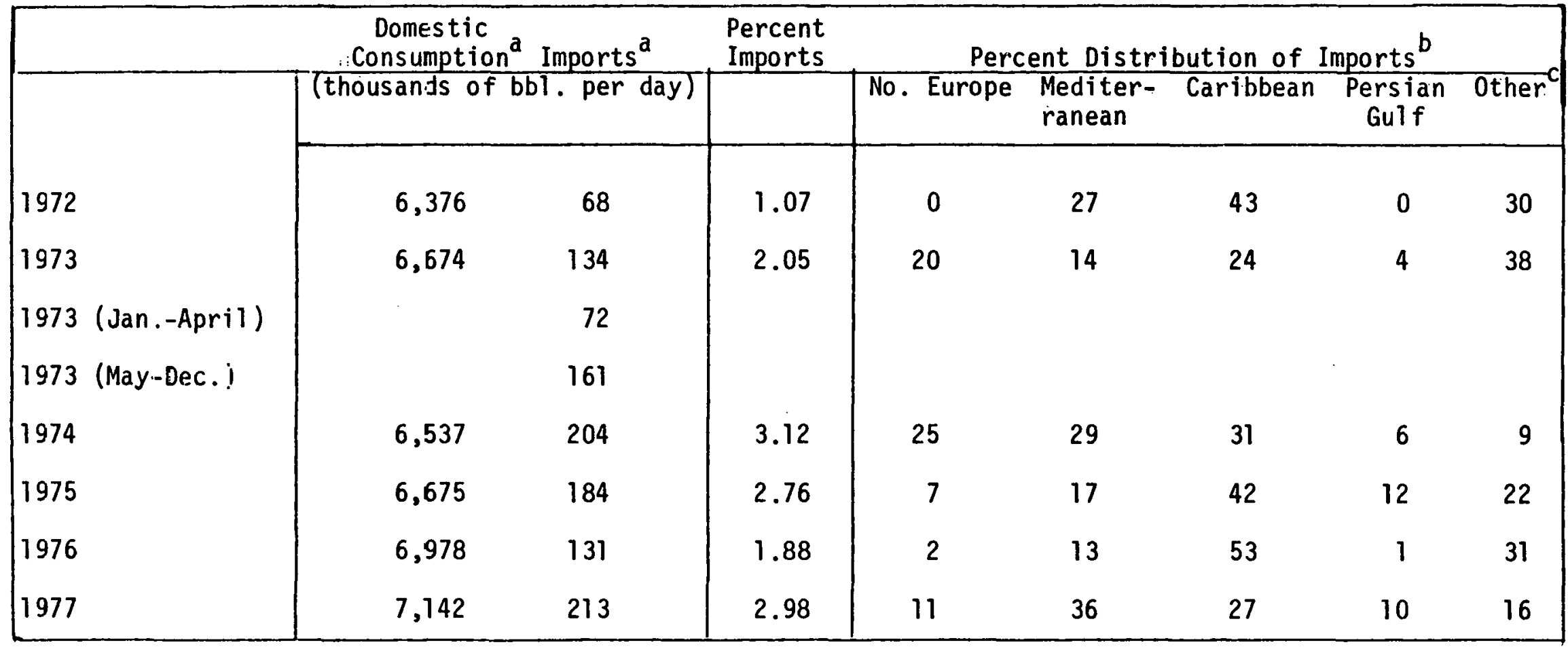

a Source: Monthly Energy Review. Figures are thousands of barrels per day.

bource: U.S. Foreign Trade Imports-Commodity by Country; U.S. Bureau of Census.

CPrimarily represents shipments from Canada, Mexico, West Africa, and the Far East. See footnote 1

(Chapter 4) for a list of countries included in the four foreign export regions. 
two different markets, except for transportation costs. This proposition requires only that buyers shop among all supply sources for the lowest delivered price, and that sellers in all markets are competitive. In the absence of trade possibilities, there is no automatic tendency for prices in different markets to equalize. Without trade, prices in a given market depend only on supply and demand conditions in that market, e.g., upon income levels, preferences, factor supplies, technology and market structures.

Figure 10 shows a domestic market for a commodity, where $S$ and $D$ are, respectively, domestic supply and demand schedules. In the absence of trade, the equilibrium price and quantity are $P_{c}$ and $Q_{C}$. To analyze the effect of trade between markets it is convenient to form an "excess demand" schedule, obtained by horizontally subtracting the supply curve from the demand curve in Figure 10. The domestic excess demand curve is shown as $E D_{D}$ in Figure 11 ; note that excess demand is zero at the (no trade) equilibrium price $P_{C}$. An excess supply curve from foreign markets (imports) may be obtained in symmetric fashion, by subtracting foreign demand from foreign supply, at each price. A foreign excess supply curve, with prices measured in the foreign market (and appropriately adjusted for currency exchange rates) is represented by $\overline{E S_{F}}$ in Figure 11 . (Hereafter, for simplicity, the "foreign market" is taken to represent all foreign countries -- the rest of the world.)

The foreign supply curve in Figure 11 is drawn under the assumption that the supply of foreign gasoline to the U.S. is highly elastic. The only estimates of which we are aware (Phelps and Smith, 1976) place this supply elasticity at about 10.0, i.e., a 1 percent increase in price would, in the absence of restrictions, induce a 10 percent increase in import supply. In the short run, it may well be that limitations in the capacity 
Figure 10

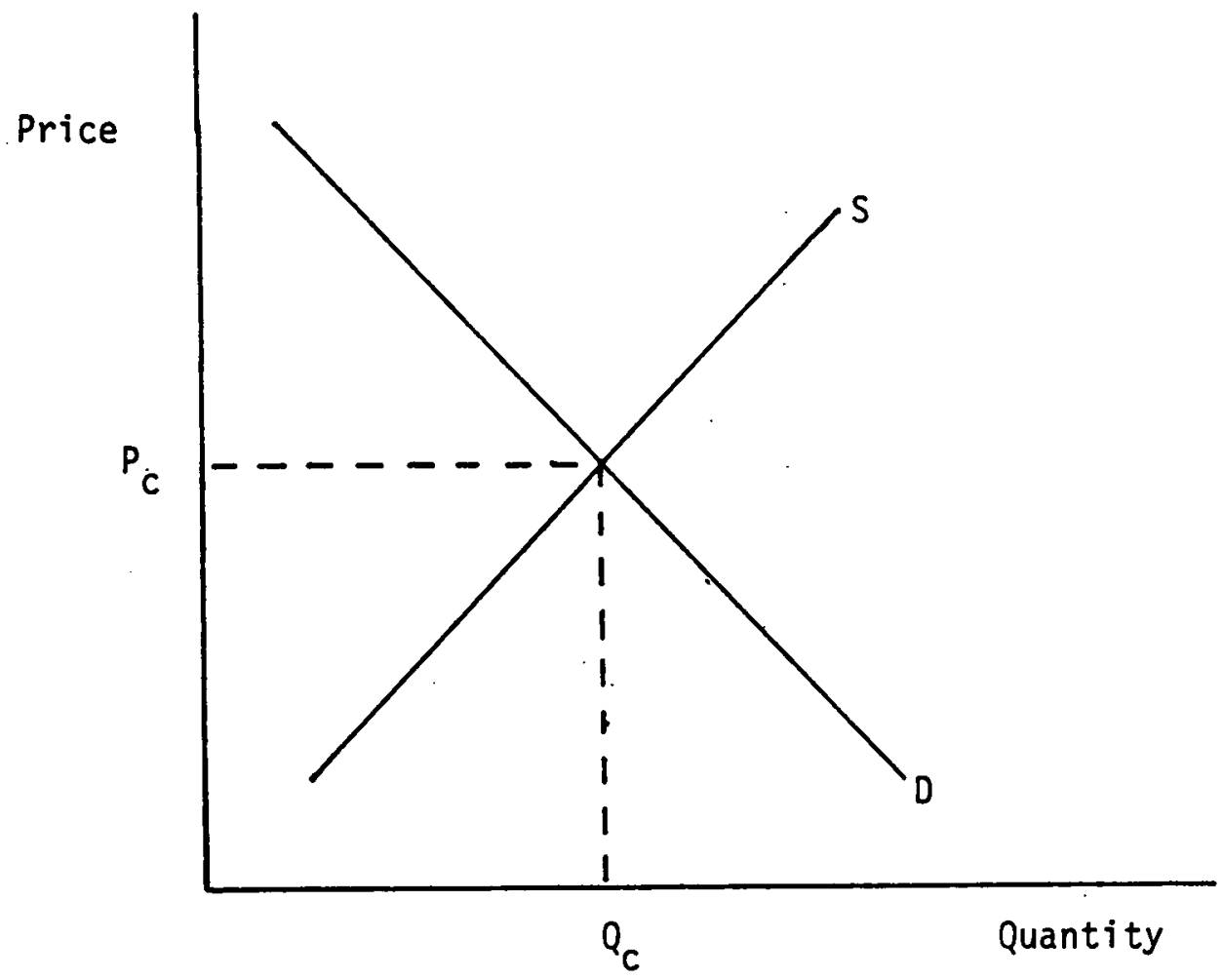

Figure 11

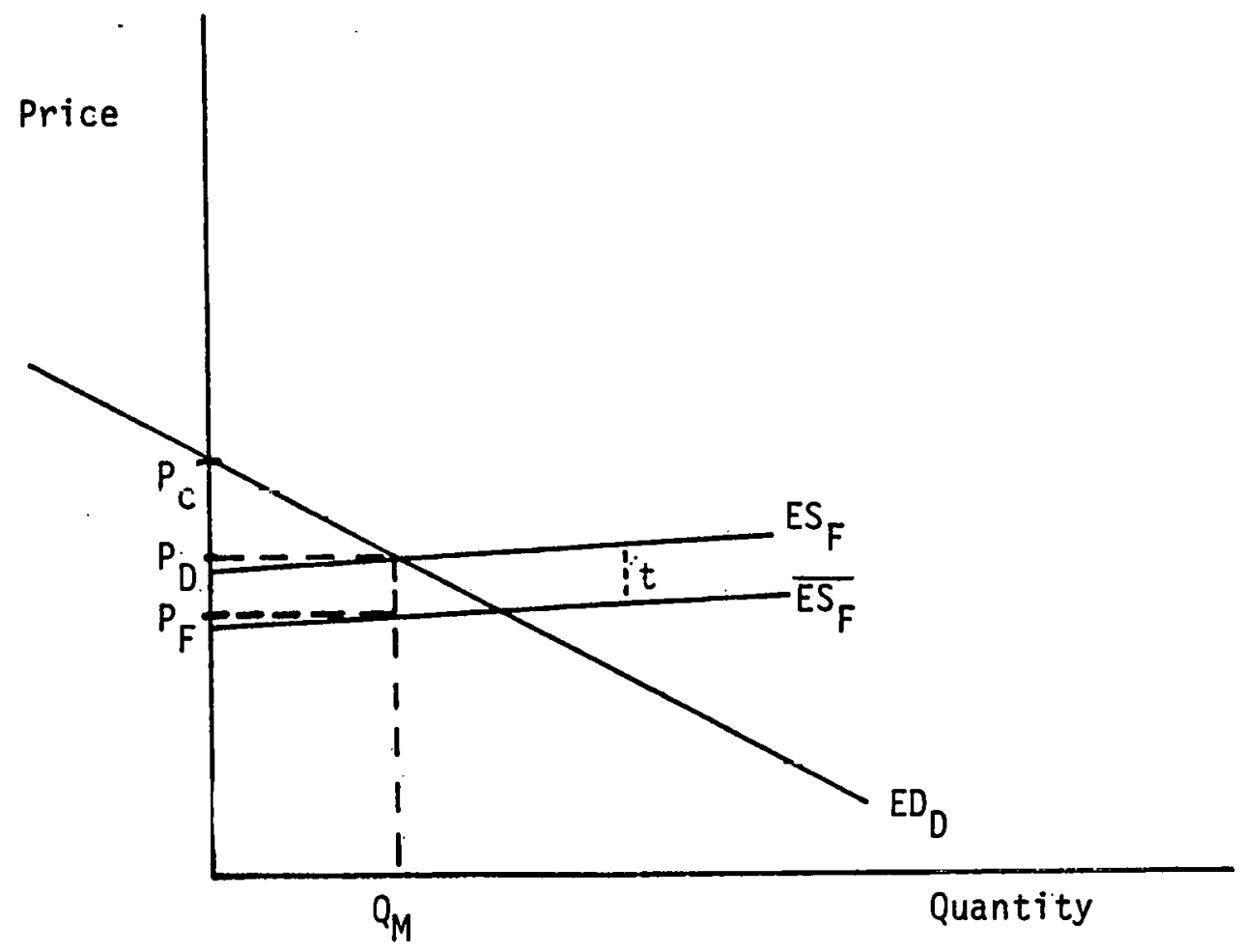


of storage and handling facilities would restrict supply increases, but these constraints would be temporary in nature.

To state foreign products in prices relevant for domestic market consideration, it is necessary to add in any costs associated with transporting the commodity between the two markets. In Figure 11 , a constant unit transport cost, $t$, (including handling, shipping, insurance, etc.) has been added to the foreign excess supply curve to yield an excess supply schedule $E_{\vec{F}}$ measured in terms of landed domestic prices. The resulting equilibrium is characterized by a domestic price $P_{D}$ (lower than the "no trade" price $P_{C}$ ) and by imports into the domestic market of $Q_{M}$ units per period. Further, notice that the equilibrium foreign price $\left(P_{F}\right)$ differs from the domestic price by exactly $t$, the transportation cost per unit.

Although the possibility of trade tends to bring prices into proximity (allowing for transport costs), the actual presence of trade (positive imports or exports from the domestic market) is not required for price equalization. If $E S_{F}$ in Figure 11 were shifted up by an amount sufficient to raise the landed foreign price (at zero supply) above $P_{c}$, no trade would occur. In this case, the difference between domestic and foreign equilibrium prices (without trade) is not sufficient to pay the freight. The purpose of highlighting this case is to point out that an absence of actual trade does not imply that prices in the two markets are unrelated; rather, the opposite is true. In the absence of trade impediments, trade will not occur only if autarkic equilibrium prices are too close. Further, the possibility of trade iimits (within $t$ ) the difference in prices in the two markets. 


\subsubsection{Trade Restrictions}

Publicly imposed trade restrictions are common and varied in form. Perhaps the most prevalent is the import tariff, an excise tax on items entering a country from abroad. Such tariffs may also be imposed by requiring any importer to obtain a license (at some stated cost per unit imported) for items purchased in foreign markets. The effect of a constant per unit tariff is equivalent to an increase in transportation cost, and its influence on foreign and domestic prices may be visualized by shifting $E S_{F}$ upward in Figure 11 , by the amount of the tariff. As a result, the level of trade is reduced (perhaps to zero) and the range of possible price differentials between foreign and domestic markets is widened. In equilibrium, however, the difference in prices will not exceed the sum of per unit tariff and transport fees.

Another common form of trade restriction is the import quota, a fixed limit upon the amount of an item that may be imported in a given period. In effect, it truncates the available supply from abroad, and tends to raise the domestic price. In Figure 12, the effect of a quota restricting import levels to $\overline{Q_{M}}$ is shown; in this diagram, the difference in foreign and domestic prices now exceeds $t$ (where $t$ includes transportation and tariff fees). In general, a quota is effective only if it induces such a price differential.

By inducing a price differential, an import quota artificially increases the value of rights to import up to the quota limit. In rigure 12, the value of a right to import (e.g., the value of a license that permits such imports) is $P_{D}-\left(P_{F}+t\right)$ per unit. If the level of the quota (supply of licenses) is set without relation to foreign and domestic prices, then the value of these import rights will fluctuate with changes in foreign and domestic supply and demand schedules. 
Figure 12

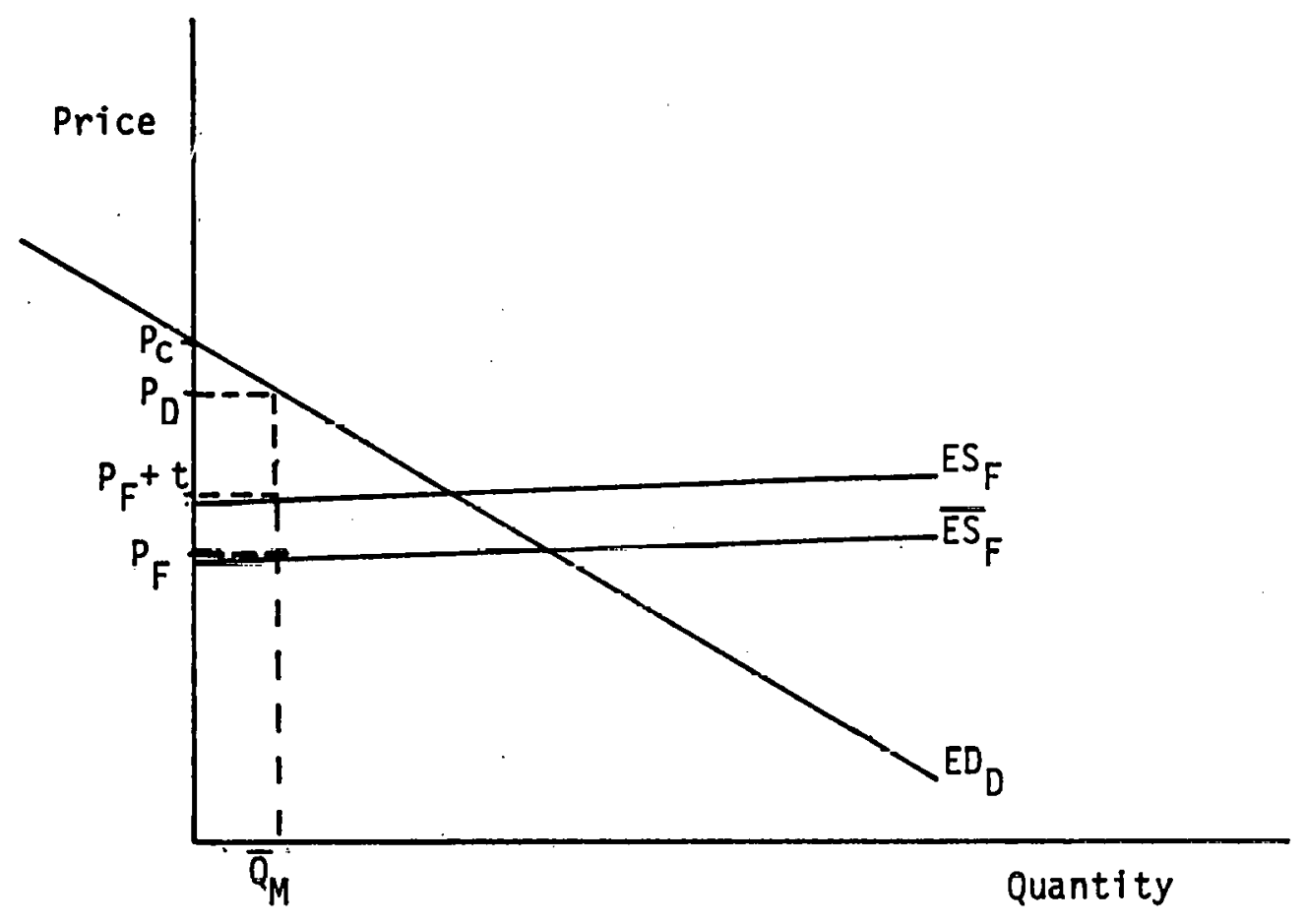


In addition to simple tariffs and quotas, other, more subtle, trade barriers may exist. These would include fees or conditions for membership in commodity trading unions, foreign exchange controls, etc. Private trade barriers may also arise it the supply of an item to a particular country is effectively monopolized. While the discussion above focussed on restrictions on imports, export controls are also possible though they tend to be much less prevalent than import restrictions. Further, the effects of export control policies are generally symmetric to import impediments, i.e., an export quota (or 7 imit) by an exporting nation yields price effects symmetric to an import quota imposed by the importing nation.

\subsubsection{U.S. Restrictions on Petroleum Imports}

In 1959, the United States instituted the Mandatory 0il Import Program (MOIP). Under this program, the continental United States was divided into two areas: (a) Districts I-IV, the region east of the Rocky Mountains, and (b) District $v$, the region west of the Rockies. A third area designated under this program was the Commonweal th of Puerto Rico. The MOIP set volumetric limits on amounts of crude oil, unfinished oils, and finished products that could be imported into each of the above three areas. Imports of gasoline, crude oil and other products were also subject to an import duty. For imports from most countries, the rate of duty on gasoline and crude oil was 1.25 cent.s per gallon and 0.125-0.250 (depending on gravity) cents per gallon respectively.

This quota system on imports of crude oil, unfinished oils, and finished products was revised on April 18, 1973. Under this program, a provision was made for a gradual transition from the existing quota method for import control to the institution of a system of license fees 
applicable to these imports. Beginning May 1, 1973, a fixed amount of crude oil, unfinished oils and finished products could be imported into the United States territory to the aforementioned three areas without payment of license fees. Volumetric limits were imposed on these imports from all countries other than Canada and Mexico. Imports in excess of these volumetric limits could be imported from abroad, but only if license fees were paid. It is interesting to note that while 1 imits were imposed on the volume of fee exempt imports of crude $0 i 1$, and unfinished products from Canada, imports of Canadian finished products were excluded from these limits. In addition to these changes, the maximum level of imports of crude oil, unfinished oils, and finished products that could be imported without payment of license fees was to be reduced for each subsequent year. Effective May 1, 1980, al1 imports of crude oil, unfinished $0 i 1$ and finished products are scheduled to become subject to license fees. (With the initial policy change, the old import duties were suspended. They were, however, reinstated in a later period as explained below.)

As stated earlier, imports over and above imposed volumetric limits were subject to license fees. There have been several changes in these regulations since May. 1, 1973. These changes are summarized in Table 4.2 and Table 4.3. Table 4.2 shows the amount of license fees effective in various time periods.

Beginning February 1, 1975, a supplemental fee of $\$ 1.00$ per harrel was imposed on all imports of crude oil, unfinished oils, and finished products. This fee was then increased to $\$ 2.00$ per barrel effective June 1, 1975. The supplemental fee was subsequently eliminated on imports effective December 22, 1975. It should be noted that the supplemental fee was waived or reduced for refiners located in territories of the United States, so that they were not treated less favorably than domestic refiners. In addition, if motor gasoline was manufactured in 
Table 4.2

IMPORT FEE SCHEDULES

(figures are cents per barrel)

\begin{tabular}{|c|c|c|c|c|c|}
\hline \multirow[t]{2}{*}{ Fee } & \multicolumn{5}{|c|}{ Effective Date } \\
\hline & $\begin{array}{r}\text { May } \\
1973 \\
\end{array}$ & $\begin{array}{c}\text { Nov. } 11 \\
1973\end{array}$ & $\begin{array}{c}\text { May 1 } \\
1974 \\
\end{array}$ & $\begin{array}{c}\text { Nov. } 1 \\
1974 \\
\end{array}$ & $\begin{array}{c}\text { Feb. }{ }^{1} \\
1975\end{array}$ \\
\hline Crude & 10.5 & 13.0 & 15.5 & 18.0 & 21.0 \\
\hline $\begin{array}{l}\text { Gasol ine } \\
\text { from Countries } \\
\text { Other Than } \\
\text { Canada }\end{array}$ & 52.0 & 54.5 & 57.0 & 59.5 & 63.0 \\
\hline $\begin{array}{l}\text { Gasol ine from } \\
\text { Canada }\end{array}$ & 0.0 & 0.0 & 5.7 & 6.0 & 63.0 \\
\hline
\end{tabular}

Table 4.3

U.S. IMPORT CONTROL POLICY

\begin{tabular}{|l|c|c|c|c|c|}
\hline & $\begin{array}{c}\text { Import } \\
\text { Quotas } \\
\text { in Effect }\end{array}$ & $\begin{array}{c}\text { Imports } \\
\text { Over and } \\
\text { Above the } \\
\text { Quotas }\end{array}$ & $\begin{array}{c}\text { Iicense } \\
\text { Import } \\
\text { Duty }\end{array}$ & $\begin{array}{c}\text { Imports Not } \\
\text { Subject to } \\
\text { Quotas }\end{array}$ & $\begin{array}{c}\text { Suppl emental } \\
\text { Fee on A11 } \\
\text { Imports }\end{array}$ \\
\hline $\begin{array}{l}\text { Pre- } \\
\text { May 1, 1973 }\end{array}$ & YES & NO & YES & --- & NO \\
$\begin{array}{l}\text { May 1, 1973- } \\
\text { Jan. 31, 1975 }\end{array}$ & YES & YES & NO & YES & NO \\
$\begin{array}{l}\text { Feb. 1, 1975- } \\
\text { Dec. 2i, 1975 }\end{array}$ & YES & YES & YES & YES & YES \\
Dec. 22, 1975- \\
Present
\end{tabular}


American Samoa, Guam, the Virgin Islands or in a foreign trade zone, and transported by vessels under United States registry, the license fee payable was at the rate applicable to the feedstock from which gasoline was manufactured.

The existence or nonexistence of import quotas, import duty, license fees, and supplementary fees are shown in Table 4.3. Note here that after February 1, 1975, both import duty as well as license fee are in effect. Regulations require only payment of either the import duty or the license fee, whichever is applicable.

\subsection{Foreign Trade and Price Controls}

A simple price control policy, where a ceiling Price $(\bar{P})$ is imposed at a level below the competitive equilibrium price is depicted in Figure 13, for a country not involved in international trade. The unsatisfied demand created by the price ceiling is, in this case, $Q_{D}-Q_{S}$. The effective excess demand in such a situation is drawn in Figure 14 as the solid line $E D_{C}$. A "shadow" excess demand curve, which would be realized if price controls were removed, is represented by a dashed line. An excess supply schedule, for foreign sellers, is shown as $E S_{F}$ and is drawn to incorporate relevant transportation charges, tariffs, etc.; i.e., it is drawn in terms of delivered prices.

If the domestic price ceiling is set below the landed forcign price, / and if the ceiling price is imposed on foreign as well as domestic product, then petroleum product imports would be expected to disappear as a consequence of price controls. Alternatively, if the landed price of foreign imports could be charged directly to consumers, excess demand would be eliminated by high cost foreign imports, while those 
Figure 13

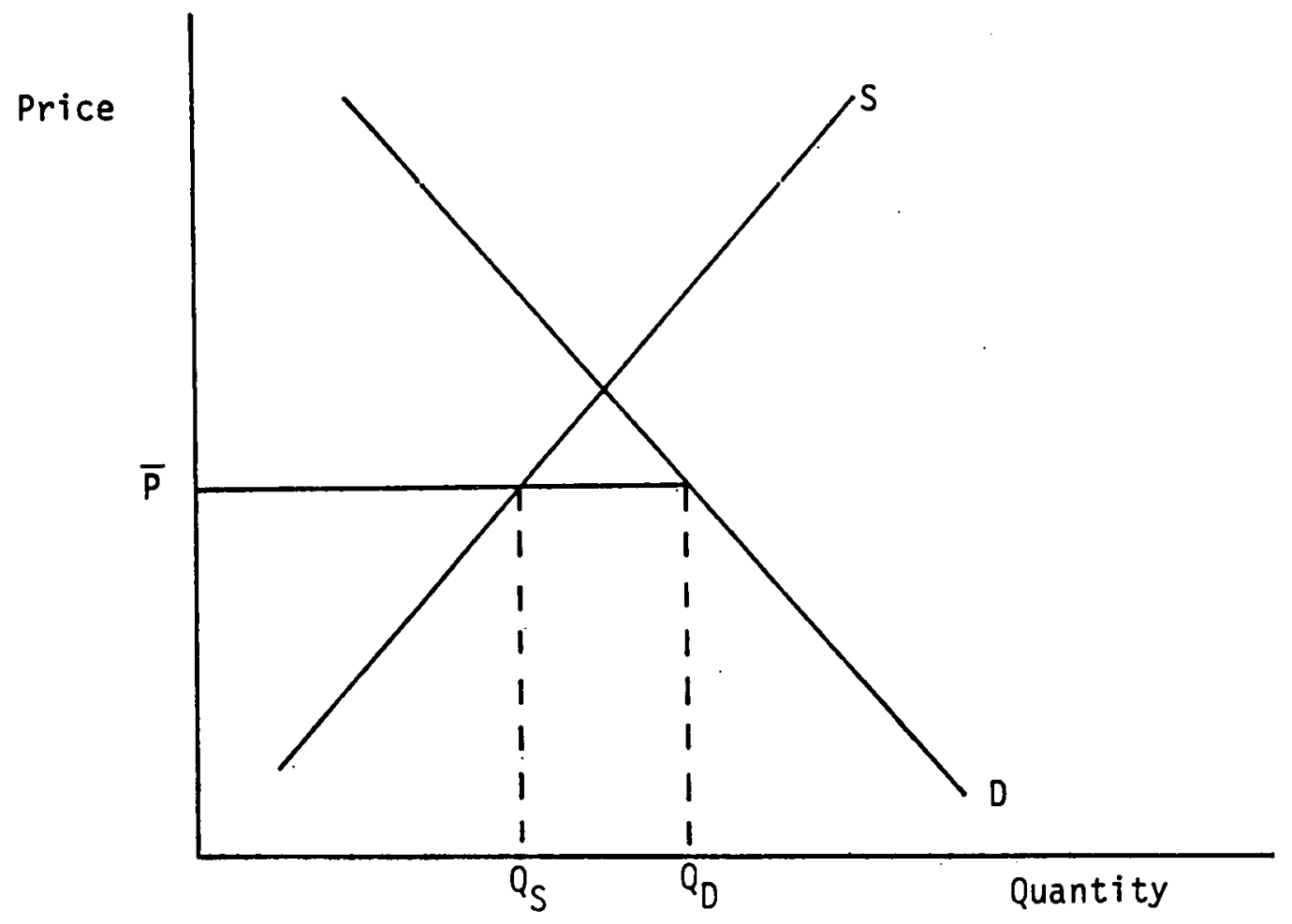

Figure 14

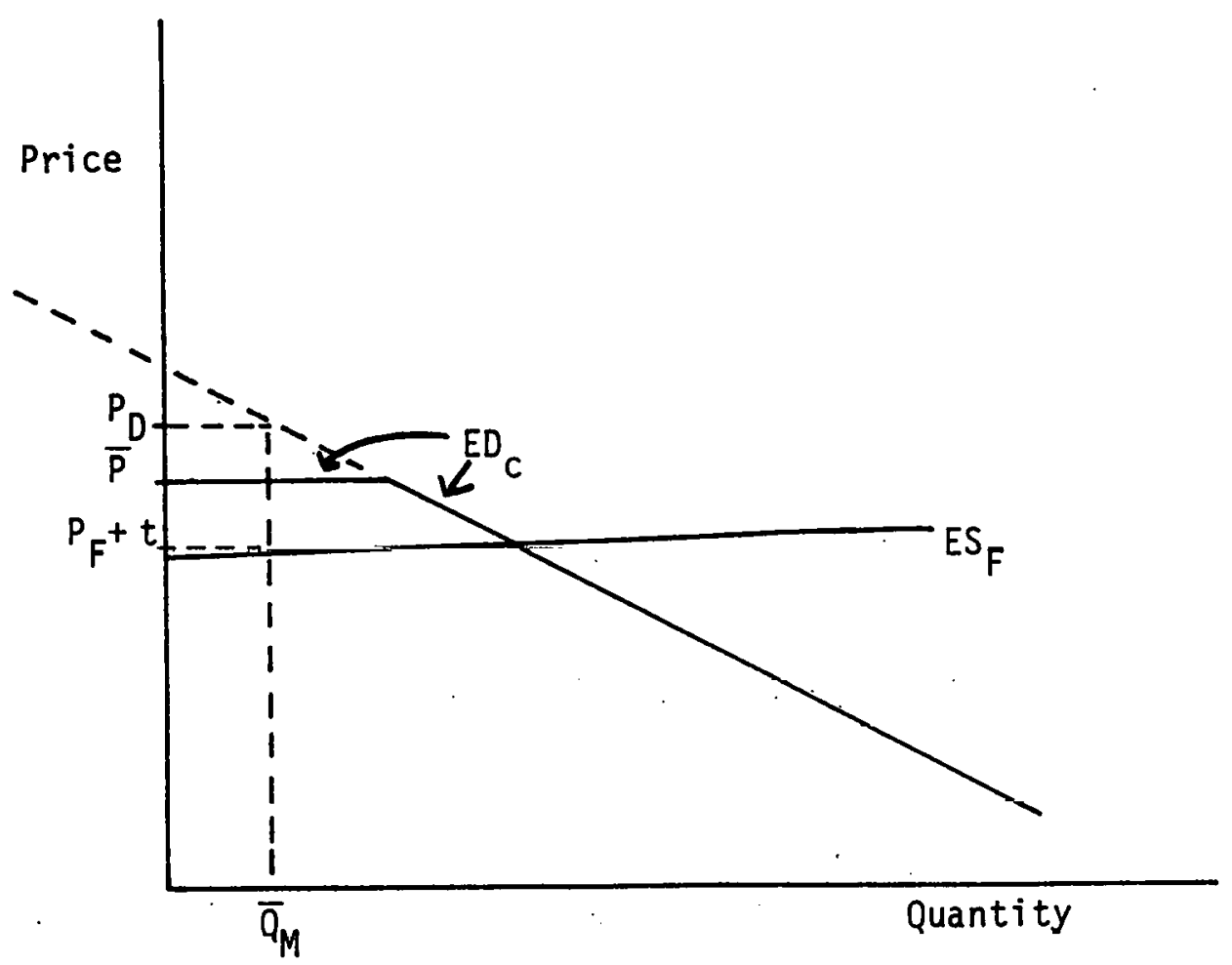


able to obtain domestic supplies would pay only the ceiling price $\bar{P}$. Under Phase I and II price controls, imported products were allowed to sell at prices above the ceiling level, but only if imports were physically separated from domestic supplies at all processing stages. Since such duplicate facilities are very costly, it seems unlikely (see Johnson, 1975) that this option was ever exercised to any significant extent.

When price controls were initially instituted in the U.S. (August 1971) import quotas on crude 011 and refined products were in effect (see Section 4.1.2). In the presence of import restrictions, and a consequent foreign-domestic price differential, binding price controls imposed in the domestic market need not eliminate imports. However, if price controls are effective then the size of the foreign-domestic price spread will be reduced (ceteris paribus) when controls are imposed. This is shown, in Figure 14 , as a controlled price differential of $\bar{P}-\left(P_{F}+t\right)$ under controls as compared to $P_{D}-\left(P_{F}+t\right)$ without domestic price controls.

\subsubsection{A More Compl icated Price Control System}

As noted in Chapter 1, the petroleum industry was singled out for specific price control treatment in early 1973. At approximately the same time, the system of mandatory crude oil and petroleum product quotas was phased out and replaced by a system of import duties levied on those not holding import licenses. With the allowance of imports above old quota levels, the constraint separating domestic and delivered foreign prices was removed. Under a simple price control system, the abolition of mandatory quotas would have been expected to eliminate either the price differential, or foreign imports. However, neither occurred and the only plausible explanation for this fact lies in the 
complexity of this new system of petroleum product price controls.

Under the system of petroleum product price controls in effect from early 1973 on, analytical statements regarding the relationship between foreign and domestic prices become difficult for two reasons. The first concerns Phase III and IV controls, and the policy of basing ceiling prices upon prices observed in an historic period plus allowances for cost increases. Further, enactment of EPAA in late 1973 gave rise to disparities in average crude oil costs across refining firms. Both policies created different price control schedules for different firms and, as noted in Chapter 3, tended to result in price dispersion. In the absence of a unique domestic price (even in a restricted geographic market area), price comparisons are complicated. If, during this period, : price controls were binding for some firms but not for others, then marginal domestic supplies are produced by unconstrained firms. The output of constrained firms is effectively limited by the price control apparatus (see Figure $5 \mathrm{~A}$ ). In such a situation foreign products could be competitive in domestic markets even if the landed foreign price exceeds the "average" price of domestic supplies. All that is required is that the price of foreign imports be competitive with the highest priced domestic output, i.e., marginal output produced by unconstrained domestic firms.

This situation is graphically portrayed in Figure 15 where $s^{d}$ represents the domestic supply curve. $P_{0}$ is the effective ceiling price for a set of constrained domestic tirms, and $Q_{0}$ is the output of these firms. That portion of the supply schedule that lies above $P_{0}$ is produced by unconstrained firms. A foreign supply curve is drawn as ${ }^{E S_{F}}$ (delivered prices). As shown, the highest domestic price is $P_{M}$ and this is received by unconstrained domestic producers and by foreign 
Figure 15

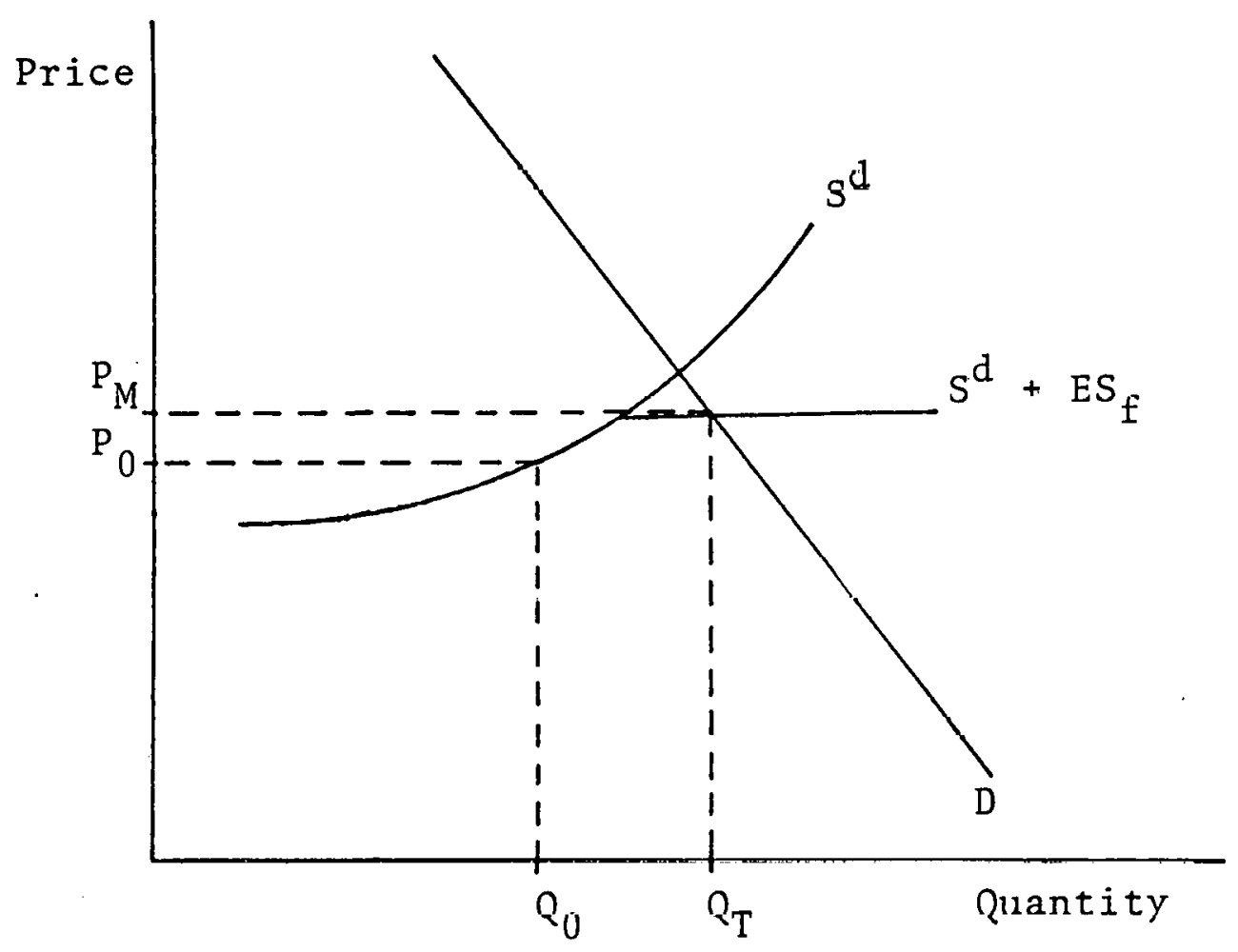


suppliers. In the situation shown, foreign supplies constrain the maximum domestic price, but exceed the average domestic price.

In addition to considerations of price dispersion, there is a second reason why foreign-domestic price comparisons must be made with caution. Under Phase III and IV controls, the cost of imported petroleum (crude oil and finished products) was allowed to pass through into the ceiling price of final products. Under this policy, price controlled refining firms may well have been willing to purchase foreign gasoline at prices that exceeded the price they were allowed to charge domestic customers. If a refining firm was effectively price constrained, one way to raise its ceiling price would be to import high cost foreign gasoline. Although the firm's average cost wouid be increased by such action, dollar-for-dollar pass throughs for imports would raise its ceiling price by the same amount; in terms of profits, the firm would be indifferent to such changes. However, purchase of imports would allow it to expand sales volume and to increase its share of the domestic market.

In the remainder of this chapter, several of the hypotheses implicit in the preceeding discussion are examined empirically. Although the primary concern is with the effect of price controls as currently implemented, the period from 1969-1977 is examined to provide corroboration for the approach used, and to trace the historic influence of various policy provisions.

\subsection{Data Used in Empirical Study of Wholesale Prices}

In this section, sources and characteristics of data used in empirical work are described. Three general types of data, foreign and domestic wholesale prices, transportation costs, and U.S. import 
fees are discussed.

\subsubsection{Wholesale Gasoline Prices}

The wholesaie price data used here were obtained from Platt's 0 il Price Handbook (1968-1977). Domestic gasoline prices (cents/gallon) are prices quoted for regular gasoline at refineries and terminals in four U.S. cities, New York, Boston, New Orleans, and Los Angeles. The period of aggregation is one month, and average monthly low and high quotations are reported. These prices are described as FOB refineries, pipeline terminals, or vessels (whichever is appropriate) and are for "open-spot" transactions with shipment available within ten days:

International wholesale prices were also obtained from Platt's (1968-1977) for four foreign trade centers, Northwest Europe (Rotterdam), the Mediterranean (Italy), the Caribbean, and the Middle East. Prices used are FOB for regular (90/92 octane) gasoline.

Prices available from Italy and Rotterdam are low and high spot quotations on the 15th day of each month. Analysis of data from these two foreign supply sources indicated that the two price series follow one another very closely over time. However, Italian prices are almost always slightly lower (about $2 \%$ ) than Rotterdam prices. This is probably due to the fact that Italian quotations are on a "cargo" basis, while Rotterdam prices are for "barge" lots and thus represent smaller quantities. The observed price differential is no doubt due to quantity discounts and, therefore, Rotterdam price data presented later should be interpreted accordingiy.

Two sources of gasoline price information were available for the Caribbean and Middle East. The first source is denoted "cargo prices," prices listed by major international market suppliers in the two regions; 
these are essentially "posted prices." Again, monthly prices for 90/92 octane regular gasoline were obtained for the period 1968-1977. Although high and low quotations were available from each region, only the average quotation for each month was collected. This practice was followed because the number and identity of individual firms reporting prices varied over the sample period; averages were used to reduce any bias that might have been involved in varying reporting practices. The second source of price information for these two regions is denoted "cargo price notes," available, by month, from Platt's for the years 1971-1973 only. These prices are considered to be a more realistic indication of actual transaction prices at mid-month for the two areas. An attempt was made to relate statistically the two sets of price data over the period when both were available. However, a simple regression of "cargo prices" on "price notes" had rather low explanatory power. An examination of the raw data indicated the following. On average, the two sets of prices differed by less than .5 cents per gallon and these differences were not statistically significant. "Cargo prices" (postings) often remain stable for several months, despite month to month fluctuations in "price notes" and are revised only if a systematic difference between the two remained for several consecutive months. Since the preferred price series (price notes) was available for only a portion of the period studied, cargo prices were used in empirical analysis.

The choice of foreign market centers was largely dictated by availability of consistently reported price data. From Table 4.1, however, it is evident that these four international supply centers account for the bulk of foreign gasoline supplies/to the U.S. The only major excluded source of import supply to the U.S. is Canada. The reasons for excluding 
Canadian price data from this analysis are discussed later in this report. 3

The four domestic market centers were chosen, in part, because they represent major population centers, and diverse geographic locales in the U.S. In addition, investigation of trade statistics for the U.S. during the period 1972-1976 indicated that most foreign gasoline (imported from the foreign supply points studied) entered U.S. customs districts I, II, V and VI (combined), and VII. Each of the U.S. cities studied is the largest population center is one of these districts.

\subsubsection{Transportation Costs}

For all of the foreign-domestic transportation possibilities studied, the relevant mode of transportation is the tanker vessel. Since 1969, it has become customary to quote tanker rates (fees paid for transporting a cargo from one port to another) in terms of "Worldscale," the Worldwide Tanker Nominal Scale. Worldscale, compiled and reported by the International Tanker Nominal Freight Scale Association, Ltd. and the Association of Ship Brokers and Agents, Inc. (various years) is essentially an estimate of the variable cost (including fuel, labor, insurance, handling port charges, etc.) of shipping a cargo from point $A$ to point $B$ in a "standard vessel." As prices of variable inputs and shipping technology change over time, these figures are updated (usually once every year or six months in recent times). Worldscale itself is not a transport fee, of course, since equilibrium tanker rates fluctuate with regional changes in the supply and demand for tanker services. However, it does provide a convenient format for reporting actual tanker rates. Worldscale figures were collected for the following foreign-domestic route combinations: 
Origin -- Rotterdam, Augusta (Italy), Quoins Island (Middle East), and Aruba, Netherlands Antilles (Caribbean);

Destination -- Boston, New York, New Orleans, and Los Angeles. Thus, data on sixteen specific port to port routes were gathered. Spot charter rates (expressed as percent of Worldscale) for the following general routes are reported in H. P. Drewry, Shipping Consultants, Ltd. (various years):
a. Northwest Europe to North America;
b. Mediterranean to North America;
c. Persian Gulf to Western Destinations;
d. Persian Gulf to Eastern Destinations;
e. Caribbean to U.S. Gulf Coast; and
f. Caribbean to U.S. Atlantic Coast.

Rates reported on these general routes were used to compute rates for specific charter trips for our. sample of foreign and domestic market centers; e.g., the Caribbean to U.S. Atlantic Coast route was taken to represent shipments from the Caribbean (Aruba, Netherlands Antilles) to Boston and New York.

Since tanker rate data were not available (in Worldscale) for 1968, this year was dropped from the analysis. For the years 1969-1970, data were not available on general routes $a_{.}, b_{.}$, and e. listed above. For these two years, charter rates on the Caribbean-U.S. Atlantic Coast route (route f.) were taken to represent rates on route e. Analysis of transactions associated on routes a. and b. was dropped from further analysis for these two years. Spot charter rates on various routes were not reported for several months during the remaining sample period. Where these missing observations related to either routes e. or $f$. (Caribbean voyages), the rate on the other Caribbean voyage was substituted. 
(Casual inspection of the data indicated that rates on routes $e$. and $f$. followed one another very closely over time.) All other missing observations were interpolated linearly from the nearest available data points.

Actual tanker rates vary with the type of cargo moved (clean versus dirty), the size of the vessel (expressed in 1000 DWCT), and the terms of the contract. For motor gasoline, the appropriate rates are "clean," which, in general, are somewhat higher than "dirty rates" appropriate for crude oil transport. Vessels in the size class 15,000-44,000 D.W.C.T. (deadweight cargo tons) dominated the "clean" traffic during the period studied. Rates are reported for two vessel sizes within this range (75,000-22,000 D.W.C.T. and 22,000+ D.W.C.T.). Since vessels of different sizes are close substitutes, rates for the two classes never diverge from one another by a large amount. However, smaller vessels usually command somewhat higher rates, perhaps owing to their greater flexibility. Figure 16 shows Average Freight Rate Assessments (A.F.R.A.) (essentially a weighted average of charter rates for all contracts in force in a given month) for vessels of different size classes over most of the period studied. The size class structure of tanker rates is evident from this figure.

A more complete set of quotations was available for vessels in the smaller size class $(15,000-22,000$ D.W.C.T.) than for larger tankers. Hence rates for this class were used in empirical analysis. To guard against the introduction of bias in using rates from this class, the percentage difference between A.F.R.A. for vessels in the two size classes was computed. These percentage differences were then used to compute estimated tanker rates for larger vessels from our rate data on small ships. 


\section{Figure 16}

AVERAGE FREIGHT RATE ASSESSMENTS (AFRA) JANUARY 1971 THRU FEERUARY 1978

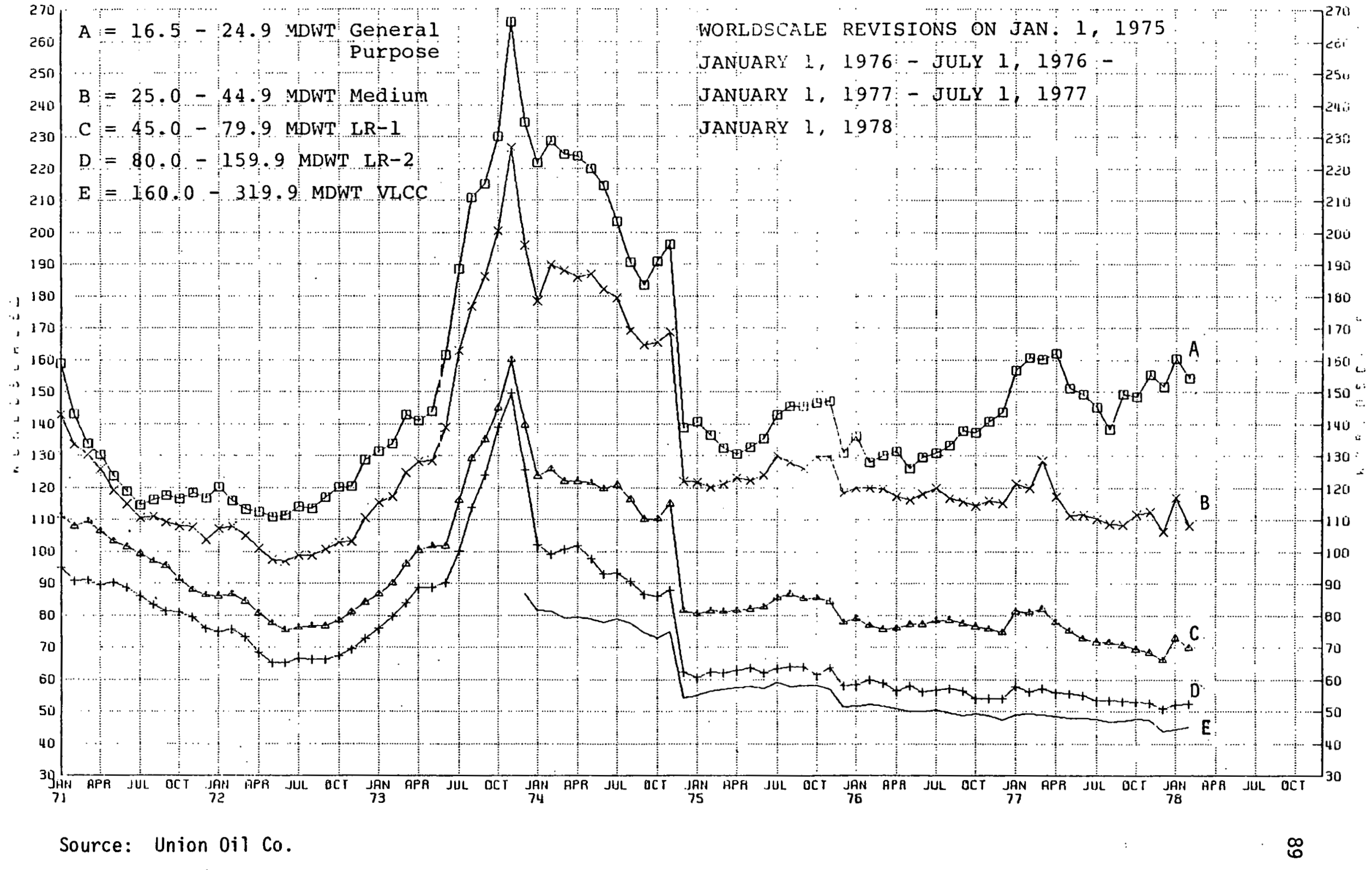


Tanker rates also vary according to the terms of the contract between shipowner and charterer. The primary distinction is between "spot" or single voyage charters and "consecutive voyage" charters. These terms are largely self-explanatory, though it should be noted that "consecutive voyage" charters involve an agreement to move a given quantity of cargo between designated ports for a specified period of time. Availability of data dictated use of "spot" rates. Further, the spot price is appropriate in a technical sense since it best indicates the instantaneous opportunity cost of transportation services in use. However, to allow for the possibility that shipping decisions were made on the basis of consecutive voyage rather than spot rates, evidence on the general empirical relationship between the two types of rates was investigated. Adelman (1972, Chapter 4) indicates that during the 1960's, consecutive voyage rates were, on average, five percent lower than spot rates. Since we are aware of no similar comparisons for the 1970's, the five percent figure was used to adjust spot data in deriving our estimated series on consecutive voyage rates.

To summarize, clean, spot rates, for vessels in the $15,000-22,000$ D.W.C.T. class were collected. Since these may exceed actual rates for larger vessels $(22,000+$ D.W.C.T.) and for consecutive voyage contracts, separate information was used to adjust these figures. Both sets of rates are used in later empirical analysis.

Finally, Worldscale figures for any origin-destination combination are sometimes computed for different transport routes, particularly where a canal transit is available. In our study, this consideration is relevant only on the Persian Gulf-West route, where shipment via the Suez Canal was available in 1976 and 1977. For these two years, data reported in Worldscale (1976 and 1977) indicated that the minimum cost 
route involved passage through the Suez Canal in 1977 only (with a canal charge of $\$ 2.00$ per ton). Likewise, toll charges for the Panama Canal were included in computed transport costs for appropriate routes.

\subsubsection{Tariffs, Duties, License Fees, etc.}

The pattern of U.S. import tariff policy on motor gasoline was summarized in Section 4.1.2. As noted, the effective total import tariff varied over time, and across firms depending upon whether or not a particular importer held an import license under MOIP. For that reason, two sets of import duty schedules were computed for the sample period and both were used in later analysis.

We were unable to discover other charges (e.g., export fees) that were not already included in the price figures reported. Many nations levy port charges on vessels using their harbors. However, these fees are explicitly included in tanker rate figures, as reported in Worldscale.

\subsubsection{Other Comments}

A11 prices and tanker rates discussed later are expressed in U.S. cents per gallon unless otherwise noted. Further, all data sources for market prices and tanker rates specifically report monetary amounts in U.S. dollars. Hence, foreign exchange conversions were not required on these data.

\subsection{Analysis of Variance on Foreign and Domestic Gasol ine Prices}

The principal statistical technique used to compare domestic gasoline prices to delivered foreign prices is analysis of variance. This is essentially a procedure for testing the significance or relevance of a particular classification of data. The data analyzed are differences between domestic wholesale prices (in four U.S. cities) and 
estimated.1anded foreign prices (from four foreign markets), where the latter are computed as the sum of F.O.B. foreign price, transportation charges (including insurance, port charges, and canal tolls where applicable), and import duties. The classifications analyzed are temporal in nature. The period studied (1969 through 1977) was broken into five "policy subperiods." Each of these subperiods was chosen to represent a distinct phase of domestic price control or import control policy. The subperiods are as follows:

\begin{tabular}{ccl} 
Period & Date & \multicolumn{1}{c}{ Description } \\
1. & pre $7 / 71$ & $\begin{array}{l}\text { Import quotas in effect; no price } \\
\text { controls. }\end{array}$ \\
2. & $8 / 1971-4 / 1973$ & $\begin{array}{l}\text { Import quotas in effect; general price } \\
\text { controls in effect. }\end{array}$ \\
3. & $5 / 1973-12 / 1974$ & $\begin{array}{l}\text { No import quotas; "pre-entitlements" } \\
\text { petroleum price controls in effect. }\end{array}$ \\
4. & $1 / 1975-6 / 1976$ & $\begin{array}{l}\text { No import quotas; "post entitlements" } \\
\text { petroleum price controls in effect. }\end{array}$ \\
5. & $7 / 1976-12 / 1977$ & $\begin{array}{l}\text { No import quotas; petroleum price } \\
\text { controls in effect (severa'l products } \\
\text { exempted, more generous allowances for } \\
\text { nonproduct cost pass-throughs). }\end{array}$
\end{tabular}

In order to isolate systematic changes in foreign-domestic price differentials, a set of regression equations was constructed in which the dependent variable is a particular foreign-domestic price differential, and the regressors are a set of dummy variables constructed to represent the five policy periods described above. Coefficients for these variables represent the expected value of the price differential in a particular period, and the usual "t statistic" is appropriate to test the hypothesis that the "expected differential" in a particular period is different from zero. In addition to the variables for 
policy periods, a set of quarterly dummy variables was also included to allow for seasonal swings in prices caused, perhaps, by seasonal demand factors. Initial experimentation with the model indicated that the classical requirement of homoscedasticity was violated. In particular, the estimated errors in the regression became large and erratic during the Arab oil embargo period (starting in October 1973). For this reason, separate regressions were estimated for the pre-embargo (prior to 10/1973) and post-embargo (after $12 / 1974$ ) periods. 5

In Chapter 3, the phenomenon of price dispersion (i.e., significant disparities between high and low price quotations) under price controls was documented. For this reason, both "average" (mean of high and low quotation) and "high" domestic prices were used in computations, and separate sets of results for the two series are reported. In foreign markets, high and low price quotations were never very far apart (less than $2.1 \$ / g a l i o n$ on average). For this reason, "average" foreign prices were used in all comparisons.

The model was estimated for each of the sixteen possible foreigndomestic combinations except European shipments to Los Angeles and cargoes from Italy to New Orleans, Differences between "avcrage domestic" and "average foreign" prices were analyzed as well as differences between "high domestic" and "average foreign" prices. Finally, regressions were estimated with and without the tanker rate adjustment factor described in Section 4.3.2. In this regard, it was found that inclusion of the tanker rate adjustment seldom caused any significant changes in our results: ${ }^{6}$ For this reason, only differences observed with the adjustment for low tanker rates (representing larger vessels and time charters) are reported here. 
4.4.1 Hypotheses Regarding Price Controls and Import Restrictions Empirical results are analyzed in terms of the following general hypotheses:

a. If, in the absence of price controls, a binding import quota is in effect, then the domestic price of gasoline will exceed the landed foreign price.

b. If, in a situation where import quotas are in effect, a binding price ceiling is imposed in the domestic market, then the foreigndomestic price differential will (ceteris paribus) be reduced.

c. Following the removal of mandatory import quotas, the landed price of foreign gasoline constrained the "average" price of domestic gasoline.

d. Following the removal of mandatory import quotas, the landed price of foreign gasoline constrained the "marginal" (high) price of domestic gasoline.

The first two hypotheses outlined above are trivial to test, and were included only to provide a check on other results. The latter two hypotheses are central to the purpose of this study and are examined for the latter three policy periods studied. A final proposition may be added to the foregoing list. This follows from the possibility that, with cost pass throughs, price constrained domestic firms may have been willing to import gasoline at prices higher than could be rharged to domestic customers. The observation of such behavior would be consistent with the proposition that price controls are binding on at least some firms .

\subsubsection{Empirical Results}

The results of comparisons between "average" domestic prices and 
landed foreign prices are shown in Table 4.4. The average domestic terminal price (cents per gallon) in each period is shown together with mean differences between the domestic price and landed prices (cents per gallon) from various foreign supply points. The mean landed price in a period may be obtained by adding the mean difference to the landed domestic price. Note that a negative difference indicates that the landed foreign price is less than the domestic price. Items appearing in parentheses are "t-statistics" for the null hypothesis that the observed difference equals zero; the critical regions for rejection at $1 \%$ and $5 \%$ significance lie above 2.8 and 2.0 respectively.

Some foreign-domestic combinations are not reported to avoid clutter. In general, a combination is not recorded if the foreign supply source was dominated (under priced) by at least one other foreign source in each period, and if historical shipping patterns indicated that the omitted route was seldom used.

The first hypothesis, on the effect of import quotas, is borne out by the figures reported for Period 1. As shown, domestic prices in New York and Boston exceeded landed foreign prices from all foreign points reported, and most of these differences are statistically significant. Essentially the same situation held in the New Orleans market with respect to shipments from Rotterdam and the Caribbean.Only in Los Angeles were domestic prices equal to or greater than delivered foreign prices; this is largely due to transport costs on these routes. The apparent price difference between European and Caribbean supplies during this period, with Caribbean gasoline bearing the premium, is partially due to differences in available data for the two periods. Due to availability of tanker rate data, the Caribbean estimates refer to the pertod 1/1969$7 / 1971$ while European estimates are only for $1 / 1971-7 / 1971$. During the 
Table 4.4

AVERAGE DOMESTIC TERMINAL PRICES AND DIFFERENCES FROM
LANDED FOREIGN PRICES

(all figures in $\$ / g a 1 . ; t$ statistics in parentheses)

\begin{tabular}{|c|c|c|c|c|c|}
\hline & $\begin{array}{l}\text { Period } 1^{a} \\
\text { pre } 7 / 7971 \\
\end{array}$ & $\begin{array}{c}\text { Period } 2 \\
8 / 197 T-4 / 7973 \\
\end{array}$ & $\begin{array}{c}\text { Period } 3 \\
5 / 1973-9 / 1973 \\
\end{array}$ & $\begin{array}{c}\text { Period } 4 \\
1 / 1975-6 / 1976 \\
\end{array}$ & $\begin{array}{c}\text { Period } 5 \\
7 / \text { T97.6-12/1977 } \\
\end{array}$ \\
\hline$\frac{\text { New York }}{\text { Terminat Price }}$ & 13.15 & 13.79 & 19.40 & 33.66 & 37.33 \\
\hline Differences: & & & & & \\
\hline N.Y. from Rotterdam & $\begin{array}{l}-5.26 \\
(3.0)\end{array}$ & $\begin{array}{l}-2.54 \\
(2.2)\end{array}$ & $\begin{array}{l}7.34 \\
(3.78)\end{array}$ & $\begin{array}{l}7.20 \\
(8.3)\end{array}$ & $\begin{array}{l}2.39 \\
(3.2)\end{array}$ \\
\hline N.Y. from Italy & $\begin{array}{l}-6.45 \\
(4.4)\end{array}$ & $\begin{array}{l}-3.89 \\
(4.0)\end{array}$ & $\begin{array}{l}5.49 \\
(3.4)\end{array}$ & $\begin{array}{l}4.43 \\
(4.8)\end{array}$ & $(0.40)$ \\
\hline N.Y. from Caribbean & $\begin{array}{l}-2.43 \\
(17.6) \\
\end{array}$ & $\begin{array}{l}-1.19 \\
(8.6) \\
\end{array}$ & $\begin{array}{l}-2.45 \\
(10.0) \\
\end{array}$ & $\begin{array}{l}4.50 \\
(9.6) \\
\end{array}$ & $\begin{array}{r}3.48 \\
(8.5) \\
\end{array}$ \\
\hline $\begin{array}{l}\frac{\text { Boston }}{\text { Terminal Price }} \\
\text { Differences: }\end{array}$ & 12.79 & 13.97 & 20.14 & 34.56 & 39.30 \\
\hline Bo. from Rotterdam & $\begin{array}{l}-4.60 \\
(2.7)\end{array}$ & $\begin{array}{l}-2.59 \\
(2.3)\end{array}$ & $\begin{array}{l}6.77 \\
(3.6)\end{array}$ & $\begin{array}{l}6.55 \\
(8.4)\end{array}$ & $\begin{array}{l}1.08 \\
(1.6)\end{array}$ \\
\hline Bo. from Italy & $\begin{array}{l}-5.82 \\
(4.3)\end{array}$ & $\begin{array}{l}-3.96 \\
(4.4)\end{array}$ & $\begin{array}{l}4.86 \\
(3.2)\end{array}$ & $\begin{array}{l}3.73 \\
(4.5)\end{array}$ & $\begin{array}{l}-1.02 \\
(1.4)\end{array}$ \\
\hline Bo. from Caribbean & $\begin{array}{l}-1.97 \\
(14.9) \\
\end{array}$ & $\begin{array}{r}-1.29 \\
(9.8) \\
\end{array}$ & $\begin{array}{l}-3.07 \\
(13.1)\end{array}$ & $\begin{array}{r}3.91 \\
(3.8) \\
\end{array}$ & $\begin{array}{l}2.27 \\
(2.5) \\
\end{array}$ \\
\hline$\frac{\text { New Orleans }}{\text { Terminal Price }}$ & 12.57 & 12.79 & 13.75 & 32.26 & 36.67 \\
\hline Differences: & & & & & \\
\hline N.0. from Rotterdam & $\begin{array}{l}-3.82 \\
(1.9)\end{array}$ & $\begin{array}{l}-1.26 \\
(9.5)\end{array}$ & $\begin{array}{l}13.74 \\
(6.2)\end{array}$ & $\begin{array}{c}9.36 \\
(11.4)\end{array}$ & $\begin{array}{l}4.11 \\
(5.8)\end{array}$ \\
\hline N.0. from Caribbean & $\begin{array}{l}-1.41 \\
(9.5)\end{array}$ & $-(1.23)$ & $\begin{array}{r}3.05 \\
(8.6)\end{array}$ & $\begin{array}{l}5.97 \\
(10.4)\end{array}$ & $\begin{array}{l}4.64 \\
(9.3)\end{array}$ \\
\hline
\end{tabular}


Table 4.4

(continued)

\begin{tabular}{|c|c|c|c|c|c|}
\hline & $\begin{array}{l}\text { Period } 1^{a} \\
\text { pre } 7 / 1971\end{array}$ & $\begin{array}{c}\text { Period } 2 \\
8 / 1971-4 / 1973 \\
\end{array}$ & $\begin{array}{c}\text { Period } 3 \\
5 / 7973-9 / 1973 \\
\end{array}$ & $\begin{array}{l}\text { Period } 4 \\
1 / 1975-6 / 1976 \\
\end{array}$ & $\begin{array}{c}\text { Period } 5 \\
7 / 1976-12 / 7977 \\
\end{array}$ \\
\hline$\frac{\text { Los Angeles }}{\text { Terminal Price }}$ & 11.68 & 12.80 & 15.46 & 33.04 & 37.63 \\
\hline Differences: & & & & & \\
\hline L.A. from Caribbean & -.13 & $\left(\begin{array}{c}54 \\
(2.3)\end{array}\right.$ & $\begin{array}{l}2.88 \\
(7.0)\end{array}$ & $\begin{array}{l}6.31 \\
\left(17^{3} .4\right)\end{array}$ & $\begin{array}{c}4.83 \\
(10.1)\end{array}$ \\
\hline $\begin{array}{l}\text { L.A. from Persian } \\
\text { Gulf }\end{array}$ & $\begin{array}{l}2.02 \\
(4.8)\end{array}$ & $\begin{array}{l}1.64 \\
(3.9)\end{array}$ & $\begin{array}{l}4.31 \\
(5.8)\end{array}$ & $\begin{array}{l}13.87 \\
(23.0)\end{array}$ & $\begin{array}{c}9.67 \\
(18.5)\end{array}$ \\
\hline
\end{tabular}

Note: Reported differences are computed as the average domestic price minus the landed foreign price; thus, a negative entry indicates that the foreign price is lower. "t statistics" are appropriate for the null hypothesis that the mean price difference is equal to zero.

${ }^{2}$ For shipments from Europe, Period 1 is 1/1971-7/1971; for other shipments, Period 1 is $1 / 1969-7 / 1971$. 
latter period, foreign F.O.B. prices appeared lower, in relation to domestic prices, than they had during the preceding few years.

The second hypothesis, that the introduction of price controls would tend to reduce domestic prices relative to foreign prices, is supported by comparisons between columns one and two. In all but one case, the foreign-domestic price differential narrowed after August 1971. (The exception is Los Angeles-Persian Gulf.) In the Northeast, the differential narrowed by about 2.0-2.75\$/gallon for shipments from Europe, and by a lesser amount for Caribbean cargoes. In New Orleans, the same general change is evident, though the absolute magnitudes of price differences are smaller in both periods. Of course, these patterns do not conclusively prove that price controls in Period 2 were binding. The observed shifts in relative prices could have been caused by changing supply and demand factors in foreign and domestic markets. One can only say that the shifts are consistent with the stated hypothesis.

The remaining hypotheses relate to Periods $3-5$. With two exceptions, landed foreign prices were significantly higher than average domestic prices in all areas studied during Periods 3 and 4 . The exceptions are on shipments from the Caribbean to the Northeast U.S. Here, it should be noted that a pattern was observed in the monthly data for foreign prices. In general, European prices remained very close together over the entire period. However, changes in Caribbean prices (and to a lesser extent, Persian Gulf prices) appeared to follow European price changes only after a delay of some months. This may be due, in part, to the nature of the Caribbean price data (see discussion in Section 4.3.1). Thus the negative differences reported for the Caribbean in Period 3 may be illusory; but we have no way of knowing for sure. The average price differentials in Periods 3 and 4 are not only 
significant, they are large in an absolute sense. They are, therefore, inconsistent with the proposition that foreign gasoline supplies effectively constrained the average price of domestic gasoline. In the absence of export controls one would expect to see domestic gasoline moving into foreign markets (particularly in Europe) under such circumstances since the price difference generally exceeded relevant transport costs in these periods.

Table 4.5 shows items relevant to the question of whether or not foreign gasoline supplies placed an effective constraint on the price of marginal (high priced) domestic supplies. Referring to columns 3 and 4 in this table, it is evident that the differentials are substantially lower. However, with the exception of Caribbean cargoes again, landed are foreign supplies/priced from 2-6\$/gallon above domestic supplies in the Northeast, and most of these differences are statistically significant. In New Orleans and Los Angeles, landed foreign prices are consistently above marginal domestic prices. With the possible exception of Caribbean gasoline in Period 3 (recall the earlier discussion of Caribbean prices). These results are inconsistent with the proposition that foreign imports constrained marginal (high) domestic prices in these two periods. Rather, they support the proposition that domestic price control policy held the price of domestic supplies below prices of foreign imports.

The estimated price differences in Periods 3 and 4 are particularly interesting in light of evidence (see Table 4.1) that gasoline was imported from Europe and the Caribbean during this time. Of course, the items in Tables 4.4 and 4.5 are really mean differences over periods of several months and it is possible that foreign prices fell below U.S. prices for brief periods. (Month to month price patterns are reported in the next section.) However, data on port to port shipments over the 
Table 4.5

HIGH DOMESTIC TERMINAL PRICES AND DIFFERENCES FROM FROM LANDED FOREIGN PRICES

(all figures in $\$ / g a 1 . ; t$ statistics in parentheses) $\begin{array}{lllll}\text { Period } 1^{\mathrm{a}} & \text { Period } 2 & \text { Period } 3 & \text { Period } 4 & \text { Period } 5\end{array}$

\begin{tabular}{|c|c|c|c|c|c|}
\hline & & 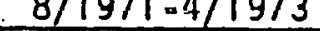 & & & \\
\hline$\frac{\text { New York }}{\text { Terminal Price }}$ & 13.15 & 13.88 & 22.66 & 34.94 & 38.66 \\
\hline Differences: & & & & & \\
\hline N.Y. from Rotterdam & $\begin{array}{l}-5.07 \\
(3.0)\end{array}$ & $\begin{array}{l}-2.54 \\
(2.3)\end{array}$ & $\begin{array}{l}4.22 \\
(2.3)\end{array}$ & $\begin{array}{l}6.22 \\
(7.0)\end{array}$ & $\begin{array}{l}1.84 \\
(2.4)\end{array}$ \\
\hline N.Y. from Italy & $\begin{array}{l}-6.26 \\
(4.6)\end{array}$ & $\begin{array}{l}-3.89 \\
(4.3)\end{array}$ & $\begin{array}{l}2.37 \\
(1.6)\end{array}$ & $\begin{array}{l}3.45 \\
(3.8)\end{array}$ & $(0.3)$ \\
\hline N.Y. from Caribbean & $\begin{array}{r}-2.37 \\
(17.5) \\
\end{array}$ & $\begin{array}{l}-1.24 \\
(9.2) \\
\end{array}$ & $\begin{array}{l}-5.65 \\
(23.5) \\
\end{array}$ & $\begin{array}{l}3.5 \\
(7.1) \\
\end{array}$ & $\begin{array}{r}2.93 \\
(6.8) \\
\end{array}$ \\
\hline$\frac{\text { Boston }}{\text { Terminal Price }}$ & 12.80 & 14.04 & 22.79 & 36.53 & 40.57 \\
\hline Differences: & & & & & \\
\hline Bo. from Rotterdam & $\begin{array}{l}-4.61 \\
(2.7)\end{array}$ & $\begin{array}{l}-2.64 \\
(2.3)\end{array}$ & $\begin{array}{l}4.18 \\
(2.2)\end{array}$ & $\begin{array}{l}4.78 \\
(6.1)\end{array}$ & $\begin{array}{c}-.02 \\
(0.0)\end{array}$ \\
\hline Bo. from Italy & $\begin{array}{l}-5.83 \\
(4.2)\end{array}$ & $\begin{array}{l}-4.01 \\
(4.4)\end{array}$ & $\begin{array}{l}2.28 \\
(1.5)\end{array}$ & $\begin{array}{l}1.95 \\
(2.4)\end{array}$ & $\begin{array}{l}-2.13 \\
(3.0)\end{array}$ \\
\hline Bo. from Caribbean & $\begin{array}{l}-1.96 \\
(12.5) \\
\end{array}$ & $\begin{array}{r}-1.35 \\
(8.8) \\
\end{array}$ & $\begin{array}{l}-5.69 \\
(20.4)\end{array}$ & $\begin{array}{l}2.13 \\
(1.9)\end{array}$ & $\begin{array}{l}1.17 \\
(1.2)\end{array}$ \\
\hline $\begin{array}{l}\text { New Orleans } \\
\text { Terminal Price }\end{array}$ & 12.57 & 12.81 & 14,00 & 34.11 & 37.82 \\
\hline Differences: & & & & & \\
\hline N.O. from Rotterdam & $\begin{array}{l}-3.79 \\
(1.9)\end{array}$ & $\begin{array}{l}-1.26 \\
(1.0)\end{array}$ & $\begin{array}{l}13.52 \\
(6.2)\end{array}$ & $\begin{array}{l}7.57 \\
(10.0)\end{array}$ & $\begin{array}{l}3.02 \\
(4.6)\end{array}$ \\
\hline N.0. from Caribbean & $\begin{array}{l}-1.90 \\
(9.8)\end{array}$ & $\begin{array}{r}-.24 \\
(1.2) \\
\end{array}$ & $\begin{array}{r}2.81 \\
(8.2) \\
\end{array}$ & $\begin{array}{l}4.18 \\
(6.9) \\
\end{array}$ & $\begin{array}{l}3.56 \\
(6.7) \\
\end{array}$ \\
\hline
\end{tabular}


Table 4.5

(continued)

\begin{tabular}{|c|c|c|c|c|c|}
\hline & $\begin{array}{l}\text { Period } 1^{\mathrm{a}} \\
\text { pre } 7 / 1971\end{array}$ & $\begin{array}{c}\text { Period } 2 \\
8 / 1971-4 / 1973 \\
\end{array}$ & $\begin{array}{c}\text { Period } 3 \\
5 / 1973-9 / 1973 \\
\end{array}$ & $\begin{array}{c}\text { Period } 4 \\
1 / 1975-6 / 1976 \\
\end{array}$ & $\begin{array}{c}\text { Period } 5 \\
7 / 1976-12 / 1977\end{array}$ \\
\hline $\begin{array}{l}\text { Los Angeles } \\
\text { Terminal Price }\end{array}$ & 11.68 & 13.05 & 17.39 & 35.02 & 38.15 \\
\hline Differences: & & & & & \\
\hline L.A. from Caribbean & $\begin{array}{r}-.10 \\
(.5)\end{array}$ & $\left(i \begin{array}{l}31 \\
i .4\end{array}\right)$ & $(2.97)$ & $\begin{array}{l}4.33 \\
(7.2)\end{array}$ & $\begin{array}{l}4.30 \\
(8.4)\end{array}$ \\
\hline $\begin{array}{l}\text { L.A. from Persian } \\
\text { Gulf } f\end{array}$ & $\begin{array}{l}2.05 \\
(5.0)\end{array}$ & $\begin{array}{l}1.41 \\
(3.4)\end{array}$ & $\begin{array}{l}2.40 \\
(3.3)\end{array}$ & $\begin{array}{l}11.90 \\
(19.9)\end{array}$ & $\begin{array}{c}9.22 \\
(17.8)\end{array}$ \\
\hline
\end{tabular}

Note: Reported differences are computed as the high domestic price minus the landed foreign price; thus a negative entry indicates the foreign price is lower. "t statistics" are appropriate for the null hypothesis that the mean price difference is equal to zero.

${ }^{a}$ For shipments from Europe, Period 1 is $1 / 1971-7 / 1971$; for other foreign shipments, Period 1 is $1 / 1969-7 / 1971$. 
period 1971 to mid-1976 indicate that gasoline imports from Northern Europe, the Mediterranean, and the Caribbean were quite common; In fact, imports from the Caribbean were observed in every month of 1974 and 1975, and imports irom Europe occurred in all but two months. The only obvious explanation for this, given estimated price differences, 1 ies in the cost pass-through provisions in gasoline price regulations. ${ }^{7}$

Period 5 spans the 19 months from July 1976 through December 1977. Between Periods 4 and 5 there was a marked trend toward equalization of foreign and domestic gasoline prices. In every foreign-domestic comparison considered, the landed foreign price fell relative to the domestic price. This is true both with respect to comparisons with "average" and "high" domestic prices. (Monthly price comparisons, presented in the next section, show that this trend toward equalization continued through 1977.) In the Boston terminal, estimated delivered prices from Europe and the Caribbean were virtually equal to (high and average) domestic prices. Of the six comparisons shown for Boston, only one is significantly greater than zero (at $1 \%$ significance). Essentially the same picture is evident in New York, though price differences are 1-2\$ higher than in Boston. Though some of the New York differences are statistically significant, the magnitudes involved are probably within the limits of confidence one can place upon the underlying data. (Recall that quantity discounts may be available for Rotterdam cargoes, and that Caribbean prices are postings.) In New Orleans the price differential fell in Period 5, but the lowest priced foreign gasoline remained about $3 \$ / g a l l o n$ above the domestic wholesale price. In Los Angeles, the price differential stood at over $4 \$ / g a l l o n$. Unfortunately, individual port to port shipment data are not available for Period 5. Thus, it is not known whether shipments to New Orleans and Los Angeles occurred during this 
period.

The price differences shown in Tables 4.4 and 4.5 for Period 5 are sufficiently small, in an absolute sense, that it is relevant to consider the seasonal factors used to adjust the price data. The seasonal dummy variables were coded in such a fashion that the differences reported in Tables 4.4 and 4.5 refer to the fourth quarter of the year (OctoberDecember). In general, the seasonal factors were small in absolute magnitude, seldom exceeding $1.5 \$ /$ gallion for any period or price comparison. However, in New York, for example, they are sufficient to reduce the price difference from Rotterdam to $0.1-0.5 \$ /$ gallon during half of the year. Likewise, the seasonal factors would reduce New York-Caribbean differences to $1.2-1.9 \$ / g a l l o n$ and Boston-Caribbean differences to $0.0-1.2 \$ / g a l 10 n$ during six months of the year. Similar seasonal patterns are evident for New Orleans; the New Orleans-Rotterdam differential was $1.3-1.5 \$ / g a l$ ion during half of the year. However, price comparisons with Los Angeles reveal differences of at least $3 \phi / g a l l o n$ in 211 four quarters.

\subsection{The Monthly Pattern of Foreign and Domestic Gasoline Prices}

To provide a visual display of the historic relationship between foreign and domestic gasoline prices, plots of monthly trends in various domestic and landed foreign prices are shown in this section. All figures are expressed in cents per gallon. Figure 17 shows the time pattern of average wholesale prices in New York versus landed prices from the two European trade centers. The close correlation between prices from Italy and Rotterdam is evident over the entire period. As noted earlier, Italian prices generally appear slightly lower than Rotterdam prices, but this difference is probably due to the fact that the latter quotations are for relatively small lots (barges). 
Average New York Terminal Price

New York from Rotterdam

New York from I taly

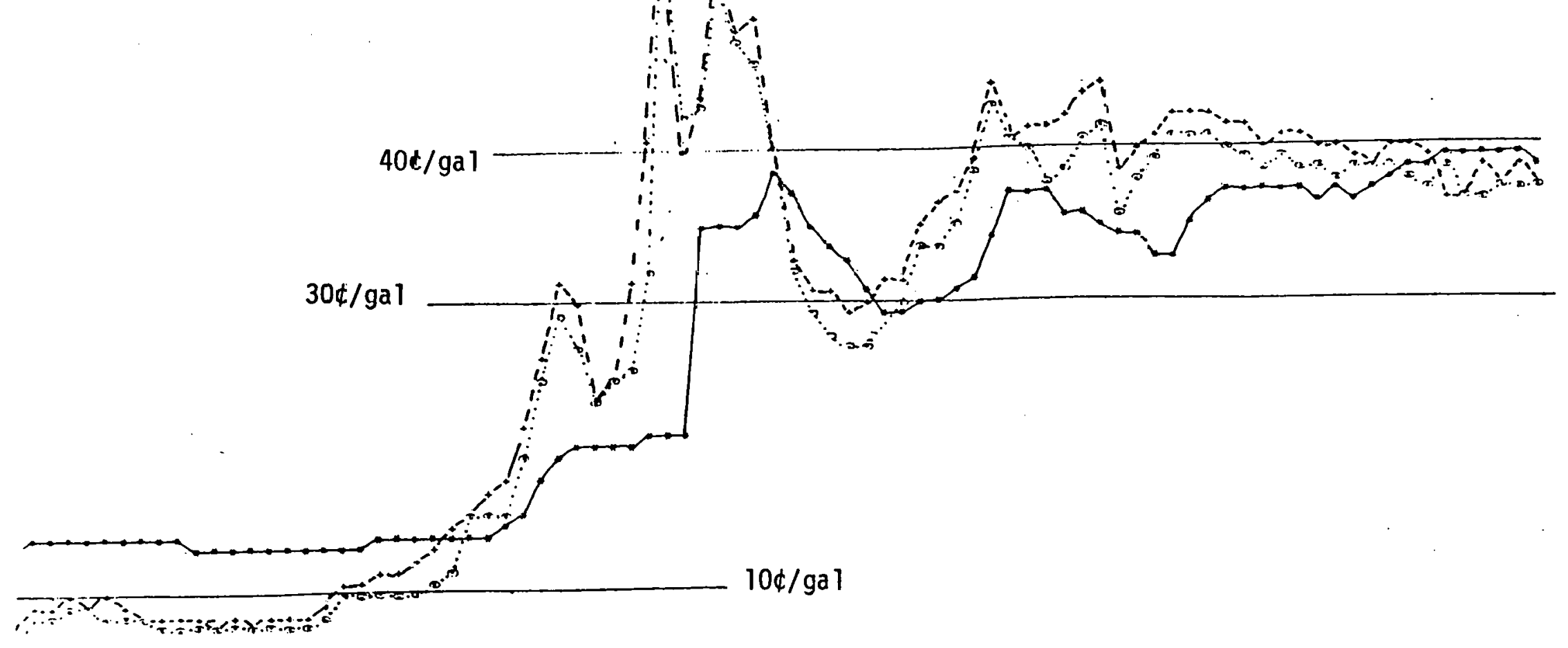


The foreign-domestic price differential (with domestic prices higher) is evident throughout most of the import quota period (prior to May 1973). However, the rise in gasoline prices on foreign markets beginning in mid 1972 was not immediately followed by domestic prices. This delay in U.S. price increases may have been caused by Phase II controls, or by the fact that the U.S. petroleum market was effectively insulated from world markets by trade restrictions. The foreign price increases experienced immediately following the 1973 war in the Middle East, and the subsequent decline in early 1974 when the Arab embargo was lifted, are the most dramatic features of Figure 17. (If one were to linearly interpolate foreign prices between mid 1973 and late 1974, the result would be a smooth rise in foreign prices, levelling off in mid 1975.) Plots of prices from the Caribbean and Persian Gulf riarkets have note been included in Figure 17 to avoid clutter. However, essentially the same pattern is evident in these series, al though the amplitude of short-run fluctuations in 1973 and 1974 is less dramatic, and foreign price changes in these markets tend to lag behind European price changes. Average New York prices followed the same general trend as European prices, but significant differences in the two series are evident. In general, the swings in foreign prices (e.g., increases starting in late 1972, late 1973, and late 1974, as well as declines experienced in early 1974 and early 1976) were followed by similar domestic price changes, but only after a delay of several montins. The delay in U.S. price increases during 1973 lasted several months.

The largest U.S. price increase was experienced in January-February 1974. After the early months of 1974, lags of 1-3 months between foreign and domestic price changes are still evident, at least until mid 1976. These lags 
would suggest that U.S. price controls (which allowed cost pass-throughs typically after a one-month delay, and oniy after costs had actually been incurred by refiners) were effective in delaying domestic price changes.

The trend toward price equalization after mid 1976 is evident from Figure 17. By May 1977, all three series had essentially converged and remained approximately equal through the balance of the year. Except for a brief period in 1974, this was the first time imported gasoline had been competitive (in the usual sense) with domestic supplies since late 1972.

Figure 18 shows plots of high New York prices against landed foreign supplies. As expected, swings in this domestic price series are more violent than those for average prices. However, the lags between foreign and domestic markets are still evident. Further, high domestic prices were below landed foreign prices during 1973-1976, except for a six-month period in the second half of 1974. As noted in the preceding section, however, foreign gasoline was imported in the U.S. Northeast throughout this period. Finally, as was the case with average price comparisons, there has been a monotonic trend toward foreign-domestic price equality since mid 1976.

Plots of foreign and domestic gasoline prices in the Boston market have not been shown since they display essentially the same features as those for New York. Figure 19 plots high wholesale quotations in the New Orleans market against delivered prices from Rotterdam and the Caribbean. Although the domestic New Orleans trend is similar to that observed in the Northeast U.S., the initial price rise experienced in Northeastern markets in early 1973 did not take place in New Orleans. In fact, the relative constancy of New Orleans prices up to early 1974 
High New York Terminal Price

New York from Rotterdam

....... New York from I taly

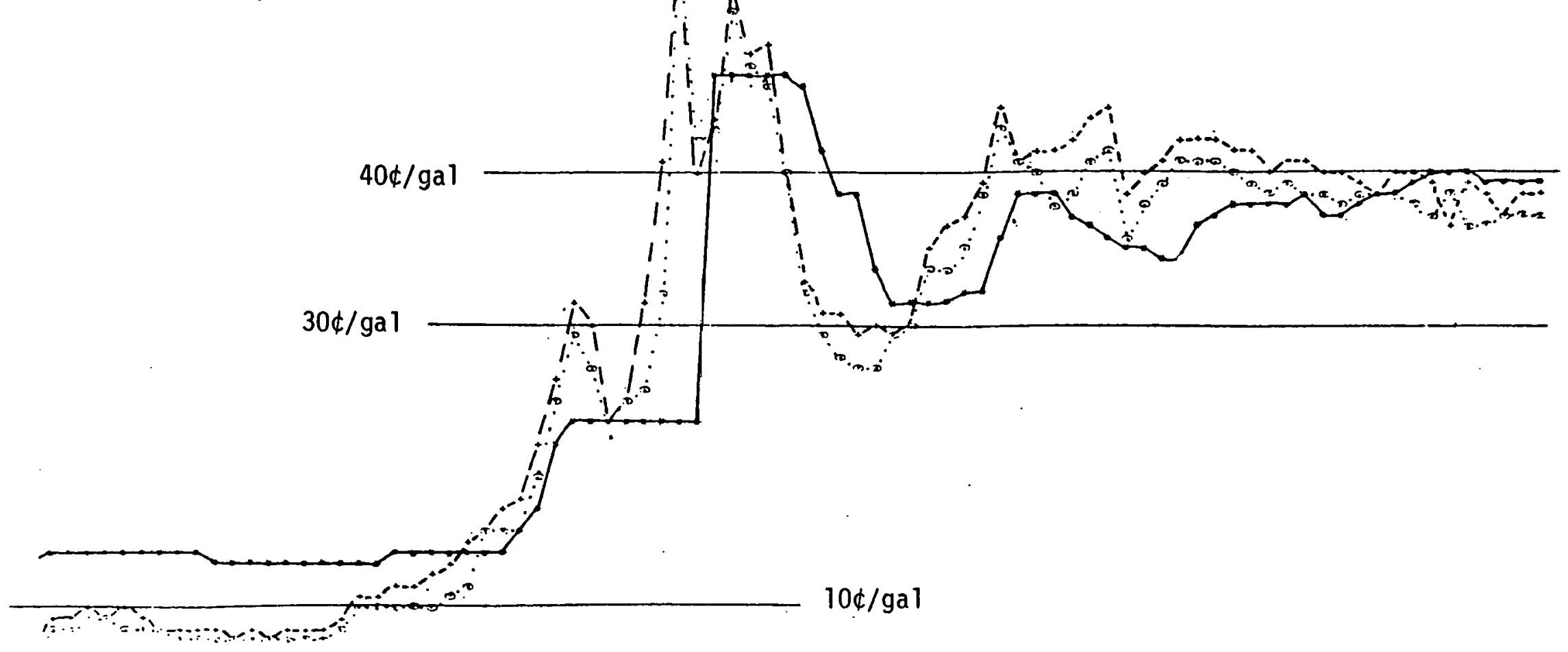


Average New Orleans Terminal Price

New. Orleans from Rotterdam

........ New Orleans from Caribbean

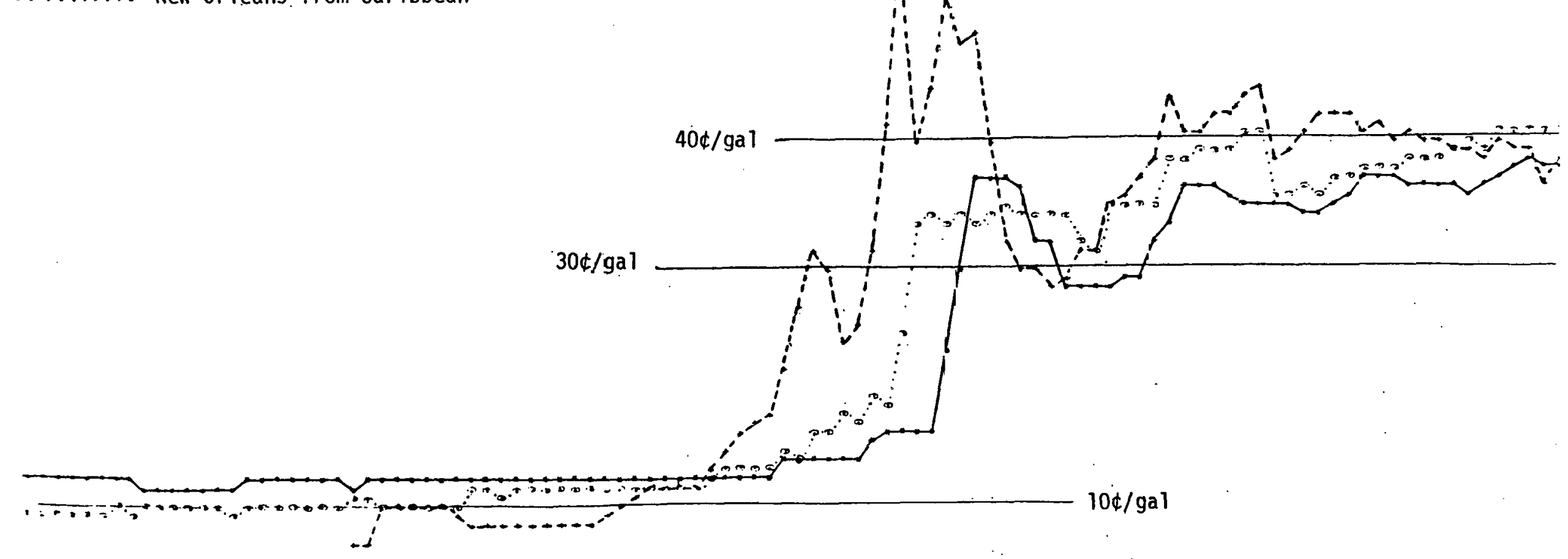

औ.

Date 
is unique among the domestic markets studied. As was the case in the Northeast, a trend toward foreign-domestic price equality (at least in terms of European prices) is evident from mid 1976 on. During the last half of 1977, there is essentially no difference between domestic and delivered European prices in the New Orleans market.

Plots showing Los Angeles prices have not been included. In summary, the Los Angeles price has remained quite stable since mid 1976, while delivered foreign prices for the routes studied have risen (primarily because of transportation costs). In effect, the Los Angeles wholesale market remains isolated from foreign competition by an estimated price differential of over $4 \$ / g a l l o n$ in late 1977.

\subsection{Conclusions}

Evidence presented in this chapter supports the following conclusions. Between May 1973 and June 1976, landed prices of foreign gasoline were higher than domestic wholesale prices, and these differences are statistically significant. This is true both with respect to average domestic prices and high domestic quotations. The observation that foreign gasoline was imported throughout this period strongly indicates the effectiveness of price cuntrols (wilh pass - through provisions for high cost foreign supplies) prior to mid 1976.

Since mid 1976 (until December 1977), there has been a clear trend toward equality in domestic and landed foreign gasoline prices. In the Northeast, the difference between U.S. prices and prices from several foreign supply sources is not statistically significant during this 19 month span of time. In New Orleans, a statistically significant difference remains for the period as a whole, but monthly data indicate that it was essentially el iminated (for New Orleans-Europe comparisons) by 
the summer of 1977. Among the domestic markets studied, only Los Angeles appears to be insulated from direct competition with foreign gasoline imports at present.

On balance, the relationships observed do not indicate that price controls constrained domestic gasoline prices in 1977. (Of course, they do not provide proof that these controls are ineffective.) If foreign prices had remained consistently above U.S. prices, and if imports continued, a constraining effect could have been inferred; however, this is not the case. Moreover, the competitive position of foreign gasoline vis-a-vis U.S. supplies is important in any consideration of decontrol. If foreign supplies to the U.S. are sufficiently elastic, they could be expected to prevent price increases if controls were relaxed. In this regard, Phelps and Smith (1976) conservatively estimated the elasticity of foreign refined products to the U.S. at about 10.0. Further, since U.S. imports of motor gasoline represent a smaller share of world production than is the case for other refined products (e.g., residual fuel oil), the gasoline supply elasticity is likely to be even larger. If the figure of 10.0 is used as a lower bound, then a $10 \%$ increase in the U.S. wholesale price (about $3.7 \$ / g a l l o n$ in 1977 ) would be sufficient to at least double gasoline imports into the U.S. This would, at present import levels, represent an approximate $3 \%+$ increase in supplies available to domestic consumers. Whether or not this supply increase would, in conjunction with Jomestic supply responses, be sufficient to prevent a rise in domestic prices with decontrol is unclear. To answer this, estimates of domestic supply and demand responșes would be required. 


\section{Chapter 5 \\ FOREIGN-DOMESTIC GASOLINE PRICE COMPARISONS \\ BASED UPON COST FACTORS}

In the present chapter, foreign and domestic prices are compared but from a different perspective than that adopted in Chapter 4. The analysis presented here ignores the influence of trade in final products upon foreign-domestic price relationships. Rather, price increases in U.S. gasoline markets experienced since the imposition of price controls are compared to price changes in an uncontrolled foreign market over the same period. Of course, such comparisons must allow for factors other than price controls, which would naturally induce price differences in the two countries. After taking such factors into consideration, then, the purpose of this analysis is to determine whether the U.S. pattern of price changes has been "abnormal" when judged against an uncontrolled situation.

\subsection{The Basis for Price Comparisons.}

The purpose of price comparisons, as analyzed here, is to view the uncontrolled foreign market as a model for what would have occurred in the U.S. without price controls. Theoretically, such comparisons would be best accomplished by estimating econometric models of gasoline markets in the two countries to control for differences in supply and demand parameters. Construction of such models is, however, beyond the scope of this study: In the absence of such estimates, it is important that the forelgn country selected for comparison be very similar to the U.S. economy. In particular, similarity in such supply conditions as production 
technologies, labor skills, qualities of other inputs, and general levels of social overhead capital are important. To insure that quality adjusted prices of labor, capital and other non-petroleum inputs are comparable in the two countries, it is desirable to choose a comparison country that is regularly involved in trade (in inputs and final products) with the U.S. and other developed nations. These considerations restrict potential comparison nations to those that are industrially advanced. Another area where similarity is desirable is in the structure (e.g., degree of competition, etc.) in petroleum markets.

Perhaps the most important area where similarity is desirable is in the mix of final petroleum products produced. Petroleum refining is a prime example of a joint production technology, i.e., a wide variety of final products are jointly produced from the primary input. In such situations, the price of an individual final product, e.g., gasoline, will be highly dependent upon demands for other refinery outputs such as jet fuel heating oil, etc. If, for example, the demand for heating oil increases relative to the demand for gasoline, then heating oil production will grow. Since gasoline is produced.as a by-product, its production will grow as well thus reducing its price. In general, this indicates that relative prices of final products will be directly related to proportions of final products produced, independent of such cost factors as input prices. 1

Even if foreign and domestic gasoline markets are similar in the respects noted above, it is quite possible that foreign and domestic prices will differ for reasons not related to price controls. Most industrialized nations obtain large fractions of crude oil supplies on international markets. Even if crude oil is purchased from the same supply source, delivered prices will differ if costs of transportation 
to refineries are different. Likewise, differences in international tariff structures and other trade restrictions will induce differences in delivered input prices. Further, variations in the structure of taxes levied on petroleum markets will give rise to international price differences. Any comparison of foreign and domestic gasoline prices must take these "macro" factors into account, and that is the primary task of the present chapter.

When correcting for such structural differences in two economies, it is important to restrict adjustments only to factors that are unrelated to the presence of price controls. It would, for example, be inappropriate to adjust prices for differences in wage rates in the refining industry, since U.S. wage rates may well, be influenced by effective price' controls on final products. Likewise, costs of delivering either inputs or refined outputs from supply centers to consumption points within the controlled economy may be affected by the presence of controls. In general, motor gasoline is a product that is complementary to some goods and services (e.g., delivery and storage services) and substitutable for others. Policies that influence the price of gasoline will alter the demands for and hence prices of related items. In the empirical analysis that follows, specific adjustments are made for cross-country differences in the delivered cost of crude oil (including transportation fees, tariffs, etc.) and for variations in the structure of taxes levied directly on the petroleum industry.

Since it is difficult, at best, to correct for all nonregulatory differences in market conditions in two economies, it is desirable to include in the analysis a period of time prior to the imposition of price controls in the U.S. Comparison of foreign and domestic prices in the absence of controls allows one to estimate the magnitude of price 
differences that are caused by factors other than those specifically adjusted for (e.g., input cost differences, taxes, etc.). If the influence of these omitted factors has remained unchanged, in a relative sense, under price controls then pre-control price differences can be compared to post-control adjusted price differences in assessing the impact of price regulations.

\subsection{The Choice of a Comparison Country}

Three criteria were used in selecting a foreign economy with which to compare the U.S. gasoline market. These are: availability of consistently reported data on gasoline prices and other requisite variables over the period studied; similarity to the U.S. economy in terms of economic development, production technology, and mix of final petroleum products produced; and the absence of government. interference in the pricing of gasoline and other petroleum products.

In terms of the first two criteria, Canada initially appeared ideal. Its general level of development, technology and refined product composition is highly similar to the U.S. Further, the mere proximity of Canada is desirable since it enhances trade in inputs and final products, and because it controls for various other factors such as weather conditions and demand patterns. However, preliminary investigation of price controls in Canada revealed a system that is highly similar to that found in the U.S. For this reason, comparisons of gasoline prices in the U.S. and Canada were not pursued further. The following section briefly outlines the Canadian system of petroleum products pricing regulations. ${ }^{2}$

5.2.1 Petroleum Industry Price Controls in Canada 3

The history of government intervention in the Canadian petroleum industry is remarkably similar to that in the U.S. In the 1950's, Canadian 
crude oil producers operated under a market prorationing system. As foreign crudes became increasingly competitive with Canadian oil in the late $50^{\prime} \mathrm{s}$, import restrictions were imposed in Western Canada. The well thead price of crude oil produced in Canada was placed under the control of the Department of Energy, Mines, and Resources in late 1973. Since that time, crude price increases have been allowed once per year, usually in July, and the price of Canadian crude has approached world levels. In April 1974 a policy that is superficially similar to the U.S. "Entitlements Program" was implemented. Exports of western crude were subjected to an export tax and the proceeds of this tax were used to subsidize imports into the Eastern portion of Canada. These policies continue in effect at the present time.

Prices on Canadian gasoline and distillates were controlled in September 1973, and this freeze was extended to all other petroleum products in January 1974. Under these controls, administered by the Department of Energy, Mines, and Resources, companies could apply for price increases based upon increased crude $0 i 1$ and nonproduct costs, i.e., a "pass-through" system. In October 1975, an economy-wide price control policy was implemented, and petroleum product price regulations came under the administration of the Anti Inflation Board (AIB).

In December 1975, general guidelines for the petroleum industry were announced. Prices could be increased only once every 90 days, following pre-notification and approved by the AIB. By February 1976, Federal price control policy had established a base period (October 19,5) from which cost pass-throughs were allowed and this policy continues at present. In addition to federal controls, provincial price controls, some dating back to early 1.973, have been implemented by several provincial governments. 
Given the complexity of Canadian controls, their extensive duration, and their rough similarity to U.S. regulations, it seemed fruitless to continue any comparison between Canadian and U.S. petroleum product prices. At best such an exercise would indicate whether Canadian controls have been more or less constraining than domestic regulations. In any case, such comparisons would not shed light upon the likely effect of decontrolling U.S. gasoline prices.

5.2.2 Price Controls in Other Developed Nations 5

Several Western European nations (including, at least, Belgium, France, Italy, and the Netherlands) instituted price control policies immediately following World War II. Under these policies, controls are applied at the retail level, and generally allow increases in ceiling prices if justified by cost increases or product price increases in foreign markets. According to Eurostat (1974) these controls were generally nonbinding prior to the late 1960 's or 1970 . Since that time, however, international crude oil prices have risen and refined product price ceilings have become constraining; in several cases, new petroleum market controls have evolved (Eurostat, 1974).

In several other nations in Western Europe, price controls are a more recent phenomenon. Prior to 1970 , petroleum prices in Denmark were subject only to general legislation regarding restrictive trade practices. Since late 1970, however, a series of price stabilization acts have been adopted and, in 1974, a price ceiling system based on input costs was established. A similar system existed in Ireland prior to 1973; after 1973, gasoline price ceilings in Ireland have been based upon prices charged by petroleum companies in other countries of the United Kingdom. (The Irish system appears to be part of a general price control system 
applied to all U.K. members in which controls are applied on a company by company basis.)

Among EEC nations, the Federal Republic of Germany is the only country that did not have direct petroleum product price controls as of 1974 (Eurostat, 1974). Since 1964, however, Germany has followed a policy designed to limit competition between petroleum products and the German coal industry. This took the form of limitations on deliveries of petroleum fuels to domestic consumers. Further, to prevent competition from abroad, imports of crude oil and refined products were made subject to government authorization (Eurostat, 1974). ${ }^{6}$ Given the joint product nature of petroleum refining, such controls could clearly affect gasoline supplies and prices. However, without more specific information on the nature of controls or production constraint levels, the magnitude of the influence cannot be estimated.

In addition to the nations discussed above, it was also established that the Japanese government sets retail petroleum product price ceilings on the basis of input costs? Several other foreign nations one might consider either operate refining and distribution systems as a government. enterprise (e.g., Mexico), or have partially nationalized their domestic petroleum industries (e.g., Norway). Regarding other potential comparison countries (e.g., Sweden, Australia, Spain), we were unable to obtain firm documentation on whether or not price controls are presently in effect. In light of the prevalence of regulations in nations for which such information was available, it seemed prudent to assume the presence of government intervention unless evidence to the contrary was forthcoming. Combining problems of data availability, and the prevalence of foreign price controls, we were able to identify only two foreign price series from developed nations that are consistently reported in both 
pre-control and post-control periods, and that are not tainted by government price regulation. These are the two series on wholesale (FOB) gasoline prices in Rotterdam and Italy examined in the preceding chapter. From these two, the price series for Rotterdam is examined in the present chapter. Italian price comparisons are somewhat problematic since the Italian government levied a turnover tax prior to early 1973 (the precontrol period). With such a tax, the amount paid depends on the degree of vertical integration in the industry and upon the way the tax is administered. We were unable to obtain detailed information on these mat ters. Regarding our price series for the Netherlands, Eurostat (1974) reports that ceiling prices apply only to domestic consumption and do not influence export prices.

In addition to wholesale comparisons between the U.S. and the Netherlands, some tentative comparisons between retail prices in the U.S. and West Germany are presented. These comparisons are considered tentative primarily because data for the period prior to the imposition of U.S. price controls (August 1971) were unavailable. Further, the presence of allocation restrictions in West Germany (noted above) must qualify any results obtained. These considerations are discussed in greater detail below.

\subsection{Data and Methodology Used in Wholesale Price Comparisons}

In comparing wholesale prices in the U.S. and the Netherlands, adjustments were made for the following production cost factors: differences in crude oil (wellhead) prices, oil transportation cost differentials, tariffs and other trade restrictions on crude oil inputs, and taxes that are specific to the production or sale of motor gasoline. The specific adjustments undertaken and sources of requisite data are explained 
in this section. Comparisons were conducted for the period January 1970July 1971 (pre-controls) and January 1976-December 1977 (post-controls). Comparisons are made for gasoline prices in four large U.S. cities, New York, Boston, New Urleans and Los Angeles.

In brief outline, the methodology l'sed consisted of estimating gasoline price differences in the U.S. and the Netherlands prior to price control regulations. Changes in the adjustment factors 1 isted above which occurred between two periods were then escimated. These alterations in cost conditions were then compared to changes in relative prices in the two countries between the two periods. In this fashion, the relationship between changes in cost conditions and changes in relative prices can be determined.

In a strict sense, this methodology is appropriate only under the assumption that production takes place at constant returns to scale in both economies. If this is the case, the supply of "refining services" will be perfectly elastic in both countries, and alterations in refining output levels will not alter the average cost of the refining activity (i.e., the refining markup). With constant returns, the change in marginal cost of refined products occasioned by a change in the delivered price of crude oil input is simply equal to the input/output ratio for refined products (see Chapter 2). Likewise, changes in tax rates on refining activities will induce corresponding changes in the refining markup, independent of any changes in output levels. In this fashion, changes in refinery markups can be related to cost changes. ${ }^{8}$

Two problems remain. Though the assumption of constant returns and elastic supply is probably accurate in the long run, capacity constraints may cause supply responses to be inelastic in the short run. To reduce the importance of such short-run considerations, comparisons are 
based upon average price and cost levels over periods of $11 / 2-2$ years. Second, even if overall refinery markups are identical in two countries, the markup on a particular product will depend upon the mix of final products produced. Since actual refinery yields differ markedly in the U.S. and the Netherlands, this is a particularly relevant empirical consideration. With joint production (of which petroleum refining is a prime example) there is no theoretically unambiguous way to attribute an input cost increase to increases in various final product costs. In empirical analysis, input cost increases were attributed to final products on a simple volumetric basis. If output ratios for various final products remain unchanged after the cost increase, this is appropriate. Further discussion of this problem appears in the text below.

\subsubsection{Crude 0i1 Costs -- Wellhead Prices}

Prior to April 1973, crude oil imports into the U.S. were constrained by a quota system. For this reason, the relevant wellhead price of crude to domestic refiners was the U.S. wellhead price (rather than a foreign price) in 1970-71. In the later period (1976-77), quotas were no longer effective, but the domestic price of crude (and, hence, domestic crude supply) was controlled. For this reason, foreign crude was the marginal supply source in the post-control period, and the foreign wellhead price (suitably adjusted for transport costs, tariffs, entitlements, etc.) is relevant for 1976-77.

For the early period, it is assumed that crude oil used by Northeast refineries came from fields in West Texas via pipeline to the Gulf Coast and tanker vessel to the final destination. ${ }^{9}$ New Orleans refineries are assumed to obtain crude from Louisiana fields, and Wilmington-Signal Hill crude is assumed to supply Los Angeles refineries. All crude oil wellhead 
prices were taken from Platts 0ilprice Handbook. The crude oil prices shown later are inclusive of gathering costs plus pipeline charges to the refinery, in the case of New Orleans and Los Angeles markets, or pipeline charges to the port of shipment (Houston, Texas) in the case of Boston and New York. Gathering and pipeline charges were taken from Foster Associates (1974). 10

In the later period (1976-77), the crude oil price series used for the U.S. is the price of Saudi Arabian crude (FOB Ras Tanura). Here, two sources of price data are available; one is supplied by Platts 0il Price handbook and the other is available from FEA (1978). In practice, the choice of a particular price series is of little importance in this period because the same crude supply source is used for both U.S. and Netherlands markets, and because the two price series agree rather closely. In ensuing empirical work, the FEA price series is used.

The choice of Saudi Arabia as a supply source for the U.S. waS reached after examining estimates of landed costs of various foreign crude oils to the U.S. (see FEA (1978)). It was found that the landed cost of Saudi crude is usually less than or equal to costs from other major exporting nations, with the possible exception of Venezuela. Venezuelan crudes, however, are of very low gravity and this probably accounts for the price difference. 11

For the Netherlands, the FOB price of Saudi Arabian crude was used in both periods. Throughout the period studied, the Netherlands has imported virtually all of its crude oil input, and Saudi Arabia and other Middle East nations have been its most important supply source. Tatle 5.1 displays relevant data on imports of Saudi and Middle East oil into the U.S. and the Netherlands..

Crude oils differ in quality, as measured by gravity and sulfur 


\section{Table 5.1}

\section{CRUDE OIL IMPORTS:}

PERCENT FROM MID EAST AND SAUDI ARABIA

\begin{tabular}{|c|c|c|c|c|}
\hline \multirow[b]{2}{*}{ Year } & \multicolumn{2}{|c|}{ Netherlands ${ }^{a}$} & \multicolumn{2}{|c|}{ U.S..$^{b}$} \\
\hline & $\begin{array}{r}\% \text { Mid } \\
\text { East }\end{array}$ & $\begin{array}{l}\text { \% Saudi } \\
\text { Arabia }\end{array}$ & $\begin{array}{l}\% \text { Mid } \\
\text { East }\end{array}$ & $\begin{array}{l}\text { \% Saudi } \\
\text { Arabia }\end{array}$ \\
\hline 1970 & 60 & 16 & -- & -- \\
\hline 1971 & 73 & 27 & -- & -- \\
\hline 1972 & 75 & 28 & -- & -- \\
\hline 1973 & 79 & 29 & -- & -- \\
\hline 1974 & 79 & 9 & 24 & 11 \\
\hline 1975 & 83 & 23 & 27 & 15 \\
\hline 1976 & 97 & 28 & 35 & 22 \\
\hline 1977 & N.A. & N.A. & 39 & 21 \\
\hline
\end{tabular}

asource: Eurostat, Hydrocarbons, Monthly Bulletin, November 1977.

bSource: U.S. Department of Commerce, U.S. General Imports and Imports for Consumption, various years. 
content, and crude oil prices reflect these differences. To insure that observed crude price differences did not merely represent quality differences, all crude prices were adjusted to a particular type of crude with gravity of $34^{\circ}$ API and $1.7 \%$ sulfur content. Since gravity-price schedules are regularly published by Platts, adjustments for gravity differences are straightforward. Price differences due to sulfur content were estimated by comparing prices for two West Texas Crudes (West Texas Sweet and West Texas Sour). For $34^{\circ}$ API crudes, the implied price difference due to sulfur content was $7.4 \phi /$ percent sulfur. This figure was used to adjust 1970-71 crude oil prices, as shown in Table 5.2. Since a common supply source was assumed in 1976-77 for both foreign and domestic refiners, no quality adjustments were necessary for this period.

Finally, the effect of the Entitlements Program upon the cost of crude oil to domestic refiners in 1976-77 must be noted. As explained in Chapters 2 and 3 , this program essentially equalizes the cost to refiners of imported crude and price controlled domestic supplies. As a result, the Entitlements Program contains an implicit subsidy for imports of crude oil. The effect of this policy upon domestic refiners' acquisition costs is discussed later in this chapter.

\subsubsection{Tanker Transport Costs for Crude 0 il}

For the U.S. market in 1970-71, the only applicable tanker transport costs are for cargoes from the Gulf Coast (Houston, Texas) to the Northeast (Boston and New York). For 1976-77, tanker charges from the Persian Gulf (Quoins Island) to all four of the U.S. cities studied are relevant. For the Rotterdam market, crude oil transport costs from the Persian Gulf are relevant cost factors in both periods.

Given the discussion of tanker freight rates in the preceding chapter, 
Table 5.2

CRUDE OIL PRICES AND ADJUSTMENTS: 1970-71

\begin{tabular}{|c|c|c|c|c|c|c|c|}
\hline $\begin{array}{l}\text { Refining } \\
\text { Point }\end{array}$ & $\begin{array}{c}\text { Crude } 0 i 1 \\
\text { Source }\end{array}$ & $\begin{array}{c}\text { Gravity } \\
0 \text { API }\end{array}$ & $\begin{array}{l}\text { Sulfur } \\
\text { Content }\end{array}$ & \multicolumn{2}{|c|}{$\begin{array}{c}\text { Wellhead } \\
\text { Price }\end{array}$} & \multicolumn{2}{|c|}{$\begin{array}{l}\text { Adjusted } \\
\text { Wellhead } \\
\text { Price }\end{array}$} \\
\hline New York & West Texas (sour) & $34^{\circ} \mathrm{C}, \longrightarrow>$ & $178 \%$ & $\$ 3.02 \quad \longrightarrow>$ & $\$ 3.31 \quad \longrightarrow \quad \longrightarrow \quad$ & $\$ 303$ & $\$ 332 \quad>>>$ \\
\hline Boston & West Texas (sour) & $34^{\circ}$ & $1.78 \%$ & $3.02>>>>$ & $3.31 \quad \longrightarrow \rightarrow \longrightarrow$ & 303 & 3.32 \\
\hline & & $\cdots$ & & & & & \\
\hline New Orleans & South Louisiana & $34^{\circ}$ & $0.20 \%$ & 3.34 & 3.59 & 3.23 & \\
\hline Los Angeles & $\begin{array}{l}\text { Signal Hill- } \\
\text { Wilmington }\end{array}$ & $34^{\circ}$ & $1.70 \%$ & 3.37 & 3.62 & 3.37 & 3.62 \\
\hline Rotterdam & $\begin{array}{l}\text { Saudi Arabia } \\
\text { (Ras Tanura) }\end{array}$ & $34^{\circ}$ & $1.67 \%$ & 1.80 & 2.78 & 1.80 & 2.18 \\
\hline
\end{tabular}

Source: Platt's 0i1 Price Handbook $(1970,1971)$. Price adjustments explained in text. Information on sulfur content was supplied by Mr. Tom Korzeniki, ARCO. 
no further discussion of the nature of tanker rate data is necessary. As before, actual rates were estimated by applying "Worldscale" for the periods and port to port shipments involved, to tanker rate quotations as reported in H. P. Drewry, Ltd. The rates used represent single voyage spot quotations for "dirty" cargoes. Tanker vessels operating these routes are assumed to be in the 100,000-140,000 DWCT class.

All shipments from Saudi Arabia to Western destinations were assumed to be routed around the Cape of Good Hope rather than through the Suez Canal. For 1970-71 this is, of course, appropriate since the canal was closed. For 1976-77, a comparison of the toll charge on canal transit (\$2.02-\$2.06/metric ton) revealed that it was virtually equal to the difference in tanker charges. Thus, as one would expect, the choice between a canal transit or voyage around the Cape of Good Hope was essentialiy a matter of indifference.

\subsubsection{Crude 0i1 Import Fees}

The structure of petroleum and refined product import tariffs in the U.S. was outlined in the preceding chapter. In the analysis presented later, the tariff rate used is that applicable for importers not possessing import licenses under MOIP. This appropriate since the supply of such licenses is fixed and thus merely confers a rent to the holder.

Information on import tariffs in the Netherlands (and other EEC nations) was obtained from two primary sources: General Agreement on Tariffs and Trade (G.A.T.T.), Basic Documentation for Tariff Study: Summary Table No. 2 -- Tariff and Trade Profile by Product Categories (Geneva, 1970), and G.A.T.T., Certification of Changes to Schedules of the General Agreement on Tariffs and Trade (Geneva, various years). The first of these documents provided tariffs imposed on various products by EEC nations, 
expressed as ad valorem rates. For BTN category 9.03 (crude petroleum) no tariffs were listed in 1970.12 The second set of documents lists periodic changes in tariff schedules imposed by nations that subscribe to G.A.T.T. These certifications were surveyed through 1974, and no changes in tariffs on crude petroleum were shown for the Netherlands. Since similar documents were not available after 1974, it was assumed that no new import tariffs on crude were imposed by the Netherlands between 1975 and 1977.

\subsubsection{Taxes on the Production and Sale of Petroleum Products}

In addition to excise and sales taxes levied at the retail level, the Netherlands imposed two specific taxes on the production of petroleum products. $^{13}$ The first of these is an excise duty levied on mineral oils and other refined products. However, since the wholesale prices used in this study are specifically stated net of such excise taxes, no corrections for changes in this tax were necessary. The second tax is a general Value Added Tax (VAT) levied at the rate of $4 \%$ on all final products. Since this is paid by the seller, and is not in the form of an excise, it is appropriate to account for it in final product prices. Although the rate was constant over the period studied, the tax is ad valorem in nature. Thus, the actual levy, as measured in cents per gallon, varies with the price of the product in question. For this reason, changes in the actual levy due to price changes were taken into account in price comparisons.

We are aware of no major changes in taxes levied directly on petroleum product refining in the U.S. during the period studied. ${ }^{14}$ Aside from excise taxes on retail gasoline sales, the primary taxes levied on petroleum operations are federal and state corporate income taxes and 
local property taxes. However, these are of a general nature and are assessed against total company operations rather than on the basis of specific refinery outputs. Thus, the effect of such taxes upon the refining markup for a particular product is difficult, if not impossible, to estimate. For these reasons, no adjustments due to tax changes were made in comparing U.S. wholesale gasoline prices between 1970-71 and 1976-77.

\subsubsection{Other Considerations}

Certain environmental controls have been instituted in both nations since 1970. In 1972, the Netherlands instituted an "anti-pollution tax." However, the rate was extremely low (about $15 \$ /$ ton when first adopted) and, in any case, is levied at the retail level. In the U.S., 1970 amendments to the Clean Air Act, and subsequent use of catalytic emission control equipment on autos produced after 1974 , led to legislation calling for reduced lead concentrations in motor gasoline. As lead was the primary octane enhancer used in motor gasoline, this legislation has apparently caused refiners some difficulty (and, perhaps, cost increases) in maintaining octane levels. As late as mid 1977, however, unleaded gasoline accounted for less than one-fourth of domestic production. Since we have no firm basis for estimating cost increases due to this factor, it was not specifically included in empirical analysis. It is, however, reconsidered in the discussion of results.

\subsection{Empirical Results on Wholesale Gasoline Prices}

Table 5.3 shows refinery yields of motor gasoline in the U.S. and the Netherlands over the period 1970-1977. The differences between the two countries are striking and illustrate a fundamental difference in final product demand patterns in the U.S. and the Netherlands. Given 
Table 5.3

REFINERY YIELDS OF MOTOR GASOLINE

(Gasoline as percent of total refinery output, by volume)

\begin{tabular}{ccc} 
Year & Netherlands & \multicolumn{2}{c}{ United States } \\
\hline 1970 & $7.8 \%$ & N.C. \\
1971 & 8.4 & N.C. \\
1972 & 8.0 & $45.4 \%$ \\
$1 S / 3$ & 8.3 & 45.6 \\
1974 & 9.3 & 45.4 \\
1975 & 12.2 & 45.4 \\
1976 & 11.5 & 44.3 \\
1977 & $11.0^{\star}$ & 43.2 \\
\hline
\end{tabular}

N.C.: not complited.

*Based upon seven months data.

${ }^{a}$ Figures are domestic gasoline production as a percent of domestic refined products demand less imports.

Sources: U.S. data from FEA (1978); Netherlands data from Euros tat (1977). 
such differences, any simple contemporaneous comparison of motor gasoline refining margins in the two countries would be meaningless. To demonstrate this, note that the Rotterdam price was about $5-7 \$ / g a l l o n$ lower than the U.S. wholesale price in 1970-71. However, the delivered cost of crude oil to refiners differed in the two countries by only $0.5-1.5 \$ / g a l i o n$, with higher crude costs found in the U.S. (due to import quotas). Such systematic differences are exactly what one would expect given the differences in demand patterns reported in Table 5.3 In the Netherlands, diesel oil and residual fuel oil are the most important refinery outputs. Because the demand for these outputs is high relative to the demand for gasoline, the supply of gasoline tends to be large relative to demand (since gasoline is in part a by-product of diesel and fuel oil production.) This leads to low prices and small refining margins for motor gasoline. Exactly the opposite is the case in the U.S., where the demand for motor gasoline is relatively intense, and computed refining margins on gasoline appear high.

While refinery yields in the two countries are clearly different, it is important to note that they remained relatively constant in the two countries over the period studied. In the U.S. the (volumetric) fraction of total refined products production represented by motor gasoline remained stable at $43-45 \%$. In the Netherlands the fraction has risen slightly, al though steadily, from about $8 \%$ to $11 \%$. This rise, though small in an absolute sense, represents a fairly large increase in relative gasoline yields and may have caused some slight increase in actual gasoine refining costs in the Netherlands.

\subsubsection{Refining Margin Comparsions}

Since comtemporaneous comparisons between countries are not 
meaningful, given differences in refinery yields, the following procedure was adopted. In each country, the change in mean gasoline prices between the pre-price control period (January 1970-July 1971) and a post-control period were computed. For the same two periods, mean changes in all identifiable cost factors were also computed. Comparing the two sets of estimates, mean changes in motor gasoline refining margins were derived and compared between the U.S. and the Netherlands. In this fashion, comparisons of actual price levels, across the two countries at a single point in time, were avoided. Rather, price increases net of cost increases were used as the basis for comparisons.

Table 5.4 displays the results of this analysis, where the pre-price control period is January 1970-July 1971, and the comparison period is January 1976-December 1977. Al1 reported figures are means derived from monthly data, and are expressed in U.S. cents per gallon. The first three rows in this table report mean prices in each of the two periods, and mean price changes between periods. Rows 4-6 report mean changes in the delivered cost of crude oil, by cost component. Changes in identifiable tax liabilities are shown in row 7 , and row 8 shows total estimated cost changes. Subtracting cost changes from price changes yields the estimated change in refining margins shown in row 9 (standard errors in parentheses). From row 9, it appears that the refining margin in the Netherlands increased substantially more $(8.8 \$ / g a l i o n)$ than did the refining margin in any of the four U.S. cities examined (1-4\$/gallon).

A critical item in U.S. crude oil cost changes was omitted from the figures in row 9. This is the subsidy on crude oil imports implicit in the Entitlements Program. As noted earlier (see Chapters 2 , and 3 ), this policy effectively reduces the net price of imported crude oil incurred by domestic refiners and roughly equalizes the cost of price controlled 
Table 5.4

CHANGES IN WHOLESALE PRICES, REFINING COSTS,

AND REFINING MARGINS

1970-71a versus 1976-77

\begin{tabular}{lccccc} 
& $\begin{array}{c}\text { New } \\
\text { York }\end{array}$ & Boston & $\begin{array}{c}\text { New } \\
\text { Orleans }\end{array}$ & $\begin{array}{c}\text { Los } \\
\text { Angeles }\end{array}$ & Rotterdam \\
\cline { 2 - 6 } 1. Wholesale Price 1976-1977 & 36.98 & 38.86 & 35.92 & 36.69 & 37.45 \\
2. Wholesale Price 1970-1971 & 13.48 & 13.12 & 12.65 & 11.63 & 6.46 \\
3. Price Change (1-2) & 23.50 & 25.74 & 23.27 & 25.06 & 30.99 \\
4. Crude 0i1 Price Change & 20.69 & 20.69 & 20.41 & 20.13 & 24.04 \\
5. Tanker Cost Change & .38 & .32 & 1.50 & 1.58 & -2.38 \\
6. Crude 0il Tariff Change & .50 & .50 & .50 & .50 & --- \\
7. Tax Change & --- & $-\cdots-$ & --- & --- & .56 \\
8. Total Cost Change (4+5+6+7) & 21.57 & 21.51 & 22.41 & 22.20 & 22.22 \\
9. Margin Change (3-8) & 1.93 & 4.23 & 0.86 & 2.86 & 8.77 \\
& $(1.45)$ & $(1.48)$ & $(1.07)$ & $(1.42)$ & $(2.85)$ \\
10. Entitlement Benefit & 5.71 & 5.71 & 5.71 & 5.71 &.-- \\
11. Margin Change + Entitlement & 7.64 & 9.94 & 6.57 & 8.57 & 8.77 \\
\hline & $(1.16)$ & $(1.51)$ & $(.91)$ & $(1.17)$ & $(2.85)$ \\
\hline
\end{tabular}

Note: A11 figures in cents per gallon. Items reported are means of monthly data for the period noted. Figures in parentheses are standard errors, computed under the assumption that the covariance between adjusted price changes in the two periods (1970-71 versus 1976-77) is zero.

\footnotetext{
a January 1970 through July 1971.
} 
domestic crude and foreign imports. To incorporate the effect of entitlements, monthly data on the crude oil entitlements benefit (the value of an entitlement received by a refiner for importing a barrel of crude oil) were taken from F.E.A., Monthly Energy Review (March, 1978), and converted into cents per galion. The mean value of an entitlement in 1976-77 appears in row 10 of Table 5.4. Deducting the entitlement benefit from domestic crude oil costs and recomputing changes in refining margins yields the figures reported in row 11, with standard errors in parentheses. With entitlements benefits included in domestic crude oil cost computations, the changes in refining markups are substantially equalized between the four U.S. cities examined and Rotterdam. Although three of the four U.S. figures are lower than the margin change in Rotterdam, the largest difference is only $2.2 \$ /$ gallon. A simple "t test" was used to examine the significance of differences in refining margin changes between the U.S. and the Netherlands (see Table 5.6 for details). Considering margin changes between 1970-71 and 1976-77, only one U.S. city (New Orleans) experienced a significantly smaller (at $1 \%$ ) margin increase than was observed in Rotterdam. Moreover, if one takes a simple average across the four U.S. cities represented, the mean change in U.S. refining margins is $8.18 \$ / g a l l o n$. This is a mere $0.6 \$ / g a l l o n$ less than was experienced in the Netherlands.

In order to make similar comparisons involving the most recent period for which data are available, the procedure followed in Table 5.4 was applied using January 1977-December 1977 as the comparison period. The resuits of these computations are shown in Table 5.5. Again, examining row 11 , it is seen that increases in refining margins between 1970-71 and 1977 were actually larger in three of the four U.S. cities than in the Netherlands. Only in New Orleans, is the margin increase lower than 
Table 5.5

CHANGES IN WHOLESALE PRICES, REFINING COSTS

AND REFINING MARGINS

$1970-71^{\text {a }}$ versus 1977

\begin{tabular}{lccccc} 
& $\begin{array}{c}\text { New } \\
\text { York }\end{array}$ & Boston & $\begin{array}{c}\text { New } \\
\text { Orleans }\end{array}$ & $\begin{array}{c}\text { Los } \\
\text { Angeles }\end{array}$ & Rotterdam \\
\cline { 2 - 6 } 1. Wholesale Price 1977 & 38.43 & 38.83 & 37.13 & 38.04 & 36.57 \\
2. Wholesale Price 1970-71 & 13.48 & 13.12 & 12.65 & 11.63 & 6.46 \\
3. Price Change (1-2) & 24.95 & 25.71 & 24.48 & 26.41 & 30.11 \\
4. Crude 0i7 Price Change & 21.59 & 21.59 & 21.31 & 21.03 & 24.94 \\
5. Tanker Cost Change & .31 & .24 & 1.42 & 1.49 & -2.46 \\
6. Crude 0i1 Tariff Change & .50 & .50 & .50 & .50 & --- \\
7. Tax Change &.-- & $-\ldots--$ & --- & --- & .52 \\
8. Total Cost Change (4+5+6+7) & 22.40 & 22.34 & 23.24 & 23.03 & 23.01 \\
9. Margin Change (3-8) & 2.55 & 3.37 & 1.24 & 3.38 & 7.10 \\
& $(.84)$ & $(.80)$ & $(.85)$ & $(.89)$ & $(2.33)$ \\
10. Entitlement Benefit & 5.44 & 5.44 & 5.44 & 5.44 & --- \\
11. Margin Change + Entitlement & .7 .99 & 8.81 & 6.68 & 8.82 & 7.10 \\
(9+10) & $(.90)$ & $(.90)$ & $(.98)$ & $(1.07)$ & $(2.32)$ \\
\hline
\end{tabular}

Note: All figures in cents per gallon. Items reported are means of monthly data for the period noted. Figures in parentheses are standard errors.

a January 1970 through July 1971. 
that experienced in the comparison country, and here the difference is less than $0.5 \$ / g a l l o n$. Further. the difference between New Orleans and the Netherlands lacks statistical significance, as shown in Table 5.6. On average, U.S. price increases exceeded those in the Netherlands by slightiy less than $1 \$ / g a l l o n$.

It is instructive to consider these estimates in light of a formal hypothesis:

Increases in the wholesale price of gasoline (net of cost increases) in the Netherlands, where prices are uncontrolled, have been less than or cqual to price increases in the U.S. under price controls.

This is the appropriate hypothesis for testing the significance of controls on domestic prices, and rejection of this hypothesis would be consistent with the proposition that U.S. price regulations are binding.

Considering the items in Table 5.6 for the comparison period 1976-1977, it is clear that the hypothesis can be rejected (at $1 \%$ significance) only for prices in New Orleans. The only other price difference that approaches significance for this period is in the Boston wholesale market where the domestic increase actually exceeded the foreign increase. For 1977 comparisons, the hypothesis stated above cannot be rejected for any of the four U.S. cities examined. Here, price increases for both Boston and Los Angeles significantly exceeded those in the Netherlands.

\subsubsection{Conclusions Regarding Wholesale Price Comparisons}

The clear indication of the foregoing analysis is that wholesale gasoline price increases in the U.S. (between 1970-71 and 1976-77) have not been "abnormal" in terms of increases experienced in the comparison 
Table 5.6

STATISTICAL TESTS FAR DIFFERENCES IN MARGIN CHANGES:

U.S. CITIES VS. NETHERLANDS

Nul1 Hypothesis: Increase in U.S. margin (including entitlements benefit) is equal to the increase in foreign margin. (Data from line 11 Tables 5.4 and 5.5.)

Alternative Hypothesis: Null hypothes is is false.

"t statistic:" (mean U.S. margin increase - mean foreign margin increase) standard error of difference in means

$$
\begin{gathered}
\text { Results } \\
\text { (computed } t \text { statistics) }
\end{gathered}
$$

Period

New York Boston New Orleans Los Angeles

1970-71 vs. $1976-77$

$-1.67 \quad 2.48$

$-3.23$

$-.28$

1970-71 vs. 1977

$1.50 \quad 3.09$

$-.59$

2.73

Critical levels for rejection (1\% significance):

$$
\begin{aligned}
& 2.704 \text { (for } 1970-71 \text { vs. 1976-77) } \\
& 2.467 \text { (for } 1970-71 \text { vs. 1977) }
\end{aligned}
$$


country. This casts doubt upon the effectiveness of U.S. gasoline price regulations, particularly as of 1977. Of course, it may be that some U.S. firms remain effectively constrained; the analysis of banked costs presented in Chapter 3 strongly indicates this. However, judging from the comparisons carried out in this chapter (and in Chapter 4) the magnitude of the constraint appears to be sma11. Price spreads (differences between high and low wholesale quotations) averaged less than $2.0 \$ /$ gallon during 1976-77 in the four U.S. cities examined. If, as seems plausible, low price quotations were forthcoming from constrained firms, these prices may be revised upward with decontrol. However, the effect upon average prices would not be expected to exceed one half of this spread, or $1.0 \$ / g a l l o n$.

Estimated differences between "cost adjusted" prices in the U.S. and the Netherlands indicate that U.S. prices were, on average, about $1.0 \$ / g a l l o n$ higher than those in the Netherlands as of 1977 . This estimated difference appears to be well within the bounds of confidence one can place upon the data used and the underlying methodology. The difference may be due to variations in environmental controls (e.g., restricting the use of lead as an octane enhancer), other public policies not taken into account, or to slight variations in product quality. In any case this price difference is not considered significant.

It. is, hnwever, evident (from lines $9-11$ in Tables 5.4 and 5.5) that the estimated effect of the Entitlements Program is largely responsible for equating the estimated refining margin across the two countries. If this program is phased out as planned, the cost of marginal (imported) barrels of crude oil to U.S. refiners will increase, and corresponding refined products price increases, perhaps mitigated by gasoline imports (see Chapter 4), can be expected. 


\subsection{Some Tentative Retail Price Comparisons}

The final set of empirical price comparisons presented in this study is based upon retail prices in the U.S. and the Federal Republic of Germany. As explained in Section 5.2, West Germany is the only developed foreign nation identified that does not directly control the retail price of gasoline (refined product allocations in Germany were noted earlier). The comparisons presented here are considered tentative primarily because they refer only to the period 1976-77. German retail price data were unavailable for the period prior to implementation of U.S. controls. ${ }^{15}$ A second qualification is that wholesale gasoline price data are not available for West Germany over the period studied. As shown in Section 5.4, refinery margins and ex-refinery wholesale prices are dependent upon refinery yields. Any analysis that fails to account for such differences will yield biassed results. To circumvent this problem, a monthly wholesale price series was estimated for West Germany for the period 1976-1977.

\subsubsection{Estimating Wholesale Gasoline Prices in West Germany} Wholesale prices for regular gasoline in West Germany were estimated from Rotterdam wholesale prices, allowing for differences in input costs and tax policies in the two countries. This procedure was followed for two reasons. First, both countries have similar refining yields, tax structures, and economic and physical environments. In 1976-77, production of motor gasoline accounted for 18\% (by volume) of refined products production in West Germany, as compared to about $11 \%$ in the Netherlands. In this respect, West Germany is much closer to the Netherlands than to the U.S. Further, governments in both countries rely heavily upon the value added tax. Second, West Germany imported over $20 \%$ of its motor 
gasoline consumption in $1976-77$ and about one half of this came from the Netherlands. Thus, there is good reason to expect that wholesale prices in the two countries will follow each other closely.

Rotterdam wholesale gasoline prices were first adjusted for differences in delivered crude oil costs in the two countries. Since West Germany imported over $47 \%$ of all crude oil input from Middle East nations, and $18 \%$ from Saudi Arabia in particular, both West Germany and the Netherlands were assumed to face a common FOB price for crude oil (the Saudi Arabian price). Regarding crude oil transport cost differences, Adelman (1973) reports that a substantial portion of German crude 011 imports are landed at Rotterdam and shipped via pipeline to German refining centers. Adelman estimated the pipeline transportation charge to be about $2 \cdot 0-2.5 \$ / 100 \mathrm{miles} / \mathrm{bbl}$. in 1970. To allow for inflation since 1970 , a charge of $4 \$ / 100 \mathrm{miles} / \mathrm{bbl}$. is used here. A representative distance of 250 miles between Rotterdam and major German cities was used to derive an estimated transportation cost figure. This amounts to a total charge of $10 \$ / \mathrm{bbl}$. or $0.24 \$ / g a l i o n$. (For shipments to the Ruhr Valley, a major industrial and refining center, a distance of $150 \mathrm{miles}$ and a charge of $.144 \$ / g a l l o n$ would be appropriate.) In general, any plausible pipeline transport cost estimate will yield delivered crude oil costs that are virtually identical in the two countries. Further, neither country (nor any other EEC nations) levy import tariffs on crude oil, so no adjustment was required for tariff differences.

In 1976-77, tax policies in West Germany and the Netherlands differed in two respects. First, since 1964 the German government has levied a production tax on petroleum products. In 1974, the most recent year for which data were available, this tax was levied at an average rate of $12.5 \mathrm{DM} /$ ton on products for which rates were reported. Since this 
rate had remained relatively constant since 1960, it was assumed to be effective in 1976-77. Using 1976 and 1977 exchange rates, this amounts to an average charge of $1.46 \$ / g a l l o n$ in these two years. The Federal Republic of Germany also levies a general value added tax at a rate of $11 \%$ as compared to $4 \%$ in the Netherlands. Thus Rotterdam wholesale prices were adjusted accordingly to take into account this cost difference.

The result of incorporating these tax adjustments is to make estimated wholesale gasoline prices in West Germany about $11 \%$ higher than those in the Netherlands during 1976 and 1977. A degree of corroboration for this estimate is obtained from the observation that Germany levies a tax of $11 \%$ on al1 refined petroleum products entering the country (Eurostat, 1974). Thus, essentially the same West German wholesale price series would have been obtained if it had been based upon the delivered price of gasoline imports.

\subsubsection{Retail Price Data}

Data on retail prices for regular gasoline in West Germany were obtained from CIA (1976-78). These prices are reported for various months in the years 1976 and 1977, and sporadically for earlier periods back to late 1973. Prior to 1973, they were not reported. These data are described as average retail prices in major West German cities. ${ }^{16}$ Spe:cific sales and excise taxes levied at the retail level are also reported. To eliminate price differences due to excise taxes, prices net of these retail taxes were recorded. The wholesale-retail markup was computed by simply subtracting the estimated wholesale price from the retail price net of tax.

In a similar fashion, wholesale-retail markups in the four U.S. cities examined were computed. Retail prices for regular gasoline net 
of State and Federal excise and sales taxes were obtained from the 0il and Gas Journal (various issues). U.S. wholesale price sources were discussed earlier.

Some comments on these series are in order. Neither retail price series reports the octane levels or types of additives that characterize "regular gasoline." Thus, some quality differences between the two countries may exist, and it is not possible to control for these. Further, the German series is essentially a national average while U.S, data refer to specific cities. Although data on average retail prices are available for the U.S., we were unable to find any corresponding series on average wholesale (terminal) prices. Thus it was not possbile to estimate an average U.S. markup. Finally, neither series reports whether retail quotations are for self service or full service retail stations, or some mixture of the two. The only description given here is that quotations are for "major branded" dealers. Given the recent U.S. trend toward "self service," even for branded dealers, this may induce some bias in computed markups. The prevalence of self service filling stations in West Germany is not known with any precision.

\subsubsection{Price Comparisons}

Table 5.7 reports retail gasoline prices (net of tax) in West Germany and differences in wholesale and retail prices in Germany and four U.S. cities. Data are shown for three months in 1976 and five months in 1977. Means and standard deviations of these data are also reported. As shown, the West German markup was greater than or equal to U.S. markups for virtually all time periods and U.S. cities examined. The only exception is in New York, where margins in the first half of 1976 exceeded those in Germany. The $t$ statistics reported in the last row of 
Table 5.7

RETAI: PRICE-WHOLESALE PRICE COMPARISONS

(all figures in cents per gallon of regular gasoline)

Retail Price
(ex tax) $\frac{\text { Retail Price (excluding tax) Minus Wholesale Price }}{\text { West }}$

Date West Germany Germany York

Boston Orleans Angeles

$1 / 76$

52.3

12.4

16.6

9.0

12.4

11.7

$3 / 76$

54.3

12.1

15.8

8.5

11.9

12.1

$6 / 76$

55.7

11.0

13.2

7.1

11.7

8.0

$1 / 77$

60.1

18.5

14.1

8.3

11.6

10.9

2/77

57.6

17.7

14.8

9.3

12.5

10.7

$6 / 77$

57.9

16.5

14.6

9.8

14.8

10.9

$9 / 77$

57.7

16.7

13.1

8.6

14.0

12.2

$10 / 77$

58.8

17.8

13.3

9.1

14.5

12.3

Mean

15.2

14.4

8.7

12.9

11.1

Std. Dev.

(2.7)

(1.2)

(0.8)

(1.2)

(1.3)

t statistic ${ }^{\mathrm{a}}$

0.62

7.19

2.65

4.35

Sources: see text.

Note: All figures in cents per gallon of regular gasoline.

${ }^{a}$ See explanation in text. 
Table 5.6 were. constructed under the null hypothesis that the mean West German markup was equal to the mean markup in the four U.S. cities. Since the critical level for rejection (at $1 \%$ ) lies above 3.0 , this null hypothesis is rejected for comparisons with Boston and Los Angeles. In these cities, U.S. markups were significantly higher than the average German markup.

Perhaps the most surprising feature in Table 5.7 is the consistent difference in wholesale-retail markups in Boston and other U.S. cities. The divergence is particularly striking when compared to New York where the mean difference in markups is over $6.5 \$ / g a l i o n$ on average. This difference led us to recheck the price series for Boston, and to examine retail price data from an alternative source (Platt's). However, the anomaly remained. The source of differences between New York and Boston markups comes primarily from retail price differences in the two cities. Wholesale prices differed by less than $2 \$ / g a l l o n$ during 1976-77, with lower prices observed in New York. Retail prices, on the other hand, were generally about $4 \$ / g a l l o n$ higher in Boston, and this difference remained fairly constant throughout 1976-1977. We have no ready explanation for this phenomenon.

Returning to comparisons with West Germany, some possible sources of bias should be noted. First, the German value added tax was not deducted from the wholesale-retail markup. Although this tax is levied directly on gasoline transactions between refiners, jobbers, and retail distributors, and it has no direct counterpart in the U.S. tax structure, the European VAT system serves much the same purpose as U.S. taxes on personal and corporate income, i.e., it is a general revenue source for the federal government. Without detailed knowledge of general tax systems on income, property; etc. in the two countries, and the effects of these 
taxes on product prices, it is not possible to correct price differences for these effects. 17 If the German value added tax had been deducted from computed inarkups, the result would have been to reduce the average markup in West Germany by about $1.7 \$ / g a l i o n$. This would essentially eliminate the difference between markups in Germany, New York and New Orleans. It would not, however, eliminate the significance of differences in the other two U.S. cities.

Another caveat concerns the difference in refinery yields in West Germany and the Netherlands and the estimation of West German retail prices. As noted earlier, West Germany produced about $7 \%$ more motor gasoline per barrel of crude oil input than did the Netherlands, and this would be expected to result in a somewhat higher refinery margin in Germany. Comparing refining margins and refinery yields in the U.S. and the Netherlands suggests that West German wholesale prices may be understated by as much as 1.2-1.3\$/galion. ${ }^{18}$ Accordingly, the margins reported for West Germany in Table 5.6 may be overstated by the same amount. Since direct evidence on gasoline refining margins in West Germany were unavail-.. able, however, this correction was not undertaken in actual computations.

Other possible sources of bias include product quality differences and the type of retail service offered in the two countries (full vs. self service). In general, one could place more condifence in these comparisons if data for a pre-price control period were available.

\subsubsection{Conclusions Regarding Retail Price Comparisons}

In sumnary, West German markups between wholesale and retail prices appeared consistently higher than those observed in major U.S. cities. On average, the differences was about $3.4 \$ / g a l l o n$, though it varies widely when computed for individual cities in the U.S. Equally significant is 
the observation that markups vary dramatically across U.S. cities and are particularly low in Boston.

The number and significance of caveats surrounding these cumparisons (in particular, the lack of data for a pre-control time period) indicate that the empirical estimates presented should be interpreted with caution. Though statistically significant differences were found, the general level of difference in U.S. and German markups ( $3.4 \$ / g a l l o n)$ is sufficiently small that it appears to be well within the bounds of confidence one can place upon the underlying sources of data. A difference of this magnitude could easily be explained by variations in product distribution costs or retail service service modes, by uncorrected differences in general tax policies or environmental restrictions, or simply by factor market conditions in the two countries. 


\section{FOOTNOTES}

*This document represents the final report for FEA contract P-03-77-6039, performed by Deacon, Mead, and Agarwal.

Chapter 1

The discussion of petroleum price controls was drawn from MacAvoy (1977), Johnson (1976), Kalt (1977), Phelps and Smith (1976), Foster Associates (1975), Federal Register (June 30, 1976) and Federal Energy Administration Guidelines.

2 For details of the Entitlements Program under EPCA, see Cox and Wright (1978) and F.E.A. Monthly Energy Review (January 1977).

\section{Chapter 2}

Tee Section 1.2.1.

${ }^{2}$ See Phelps and Smith (1976), pp. 50-53 (and Figure 3) for a particularly clear explanation.

${ }^{3}$ This estimate is erroneous for periods after April 1973. See Chapter 4.

${ }^{4}$ This estimate appears unrealistically low. It is based upon a rather unsuccessful regression model estimated by Phelps and Smith which indicated that a $\$ 1.00 / \mathrm{bbl}$. increase in crude oil costs only raised domestic refined product prices by $\$ .45 / \mathrm{bbl}$. The remainder was presumably absorbed by owners of capital that is specific to the industry (in reduced rents). The over all probability that statistical relationships estimated in the entire model was merely due to chance was $17 \%$.

See Phelps and Smith, pp. 29-32.

\section{5}

Notice that profits are zero at all price quantity combinations along curve $\bar{p}$ in Figure 4 . Thus, by itself, the profit motive will not naturally favor point $c$ over other points on this schedule. It is reasonable to argue, however, that firms also wish to expand market shares (particularly when such action does not adversely effect profit). Such behavior would naturally lead to point $c$ since it is the largest industry output consistent with the price ceiling schedule and the market demand function. 
The following discussion of refined product demand under price controls was adapted from a suggestion by David Mead.

${ }^{2}$ At successively higher values of $P$, the curve $\bar{D}$ would approach a vertical line representing the industry output of price controlled product. Chapter 5.

${ }^{3}$ An implicit subsidy for gasoline production is estimated in

${ }^{4}$ Kalt (Table 4) and Roush (pp. 72,73) present evidence that is in broad agreement with these predictions.

5 Upon completion of this analysis it was found that monthly market share data are available for the three categories of refiners. Examination of these data revealed some variation in these shares, particularly, a decline in the share of "large integrated" relative to "small independent" refiners. However, since none of the shifts in shares exceeded five percentage points, the 1974 data appear adequate to identify general trends in industry banked costs.

6 Our sample excluded two firms in the "large integrated" class and two firms in the "large independent" class. In computing the figures in Table 3.1 it was assumed that these firms experienced binding price constraints exactly as often as did the average firm in our sample. A similar assumption was made for small firms not included in our sample. Since the two larger categories accounted for over $82 \%$ of sales in 1974, and because only two firms were excluded from each of these categories, any biases introduced with this procedure should be small.

\section{Chapter 4}

${ }^{1}$ Due to the way in which data are reported, gasoline imports in Table 4.1 include shipments from U.S. Territories, such as Puerto Rico and the Virgin Islands, to the 50 states and the District of Columbia. Thus, the relative importance of gasoline imports from foreign nations is overstated. Items in the last five columns of this table represent the percentage distribution of imports from foreign nations. Specific countries included in each of the four foreign regions distinguished are listed below.

Northwest Europe: Belgium, Finland, France, Netherlands, Sweden, United Kingdom, West Germany;

Mediterranean: Greece, Italy, Romania, Spain, Turkey;

Caribbean: Brazil, Colombia, Leeward and Windward Islands, Netherlands Antilles, Panama, Trinidad, Venezuela;

Persian Gulf: Bahrain, Iran, Iraq, Kuwait, Oman, Quatar, Saudi Arabia.

${ }^{2}$ More specifically, a nominal quota system remained in effect, though it ceased to be binding. See Section 4.1 .2 for further detail. 
3 In brief, Canada was excluded due to the existence of wholesale price controls in Canada and rather complex export restrictions over part of the period studied.

${ }^{4}$ For a discussion of this procedure see Goldberger (1966); Chapter 5, Section 3.

${ }^{5}$ As a consequence, Period 3 was truncated to the time span May 1973-September 1973.

${ }^{6}$ The only exceptions were for shipments from the Persian Gulf. In general, Persian Gulf gasoline was seldom found to be competitive with supplies from other foreign sources and thus is a largely irrelevant foreign supply source.

${ }^{7}$ It might be argued that such shipments were based upon long-term contracts, set prior to the imposition of controls. Faced with such a contract, however, one would expect an importer to fulfill domestic supply obligations by purchasing relatively low-priced U.S. gasoline and to sell his foreign gasoline supply in the world market.

Chapter 5

This could be restated by saying that the marginal cost of producing output $A$ is related to the amount of jointly produced output $B$. If the production technology exhibits the usual convexity properties, the relationship will be an inverse one, i.e., if output of $B$ is relatively high, the marginal cost of A will be relatively low.

2 Initial inquiry indicated that Canadian controls were a rather recent phenomenon and that comparisons prior to 1976 would be appropriate. (The Canadian Energy Research Institute (Ellison, 1978) conducted petrol eum product price comparisons between Canada and the U.S., and never mentioned Canadian regulations on final product prices.) However, preliminary scrutiny of Canadian price data prompted further investigation of the Canadian regulatory structure.

${ }^{3}$ The synopsis of Canadian regulation of crude oil prices is taken from Ellison (1978). 
${ }^{4}$ The discussion of refined product price controls is drawn primarily from "Federal Government Price Controls," Imperial 0il Co., Ltd. (mimeo), 1978.

${ }^{5}$ Unfortunately, there appears to be no single source of information on petroleum market price controls in foreign nations. The following discussion, as it pertains to member nations of the European Economic Community (EEC) is based upon Eurostat (1974) and covers the period through 1974.

${ }^{6}$ Eurostat (1974) states only that there were limits on deliveries of oil fuels. No specific discussion is offered regarding the existence or magnitude of mandatory gasoline allocations.

${ }^{7}$ Evidence regarding Japanese controls was obtained from C.I.A. (1977) and by personal communication from John Boatwright, Exxon.

${ }^{8}$ Thus, capacity constraints are assumed to be nonbinding at the industry level. Even if refining takes place at constant returns to scale (as assumed here) it is still possible for refined product supply schedules to be upward sloping. However, given constant returns, this would be due only to upward sloping supply schedules (at the industry level) for refining inputs.

${ }^{9}$ The possibility that Northeastern refiners obtained crude $0 i 1$ supplies from Louisiana and the Gulf Coast fields was also considered. However, differences in delivered prices from the two sources were too small to be relevant $(0.1-0.2 \phi /$ gallon $)$.

${ }^{10}$ The estimates supplied by Foster Associates are for early 1973. However, the gathering charges involved are so small (less than $0.5 \$ / g a i l o n)$ that no attempt was made to revise these figures to reflect the 1970-71 period.

${ }^{11}$ In 1977, the bulk of Venezuelan crude landed in the U.S. was of gravities less than $25^{\circ}$ API, whereas the opposite was true for all other major U.S. supply sources. See U.S. Department of Commerce (1976), Table 2.

${ }^{12}$ As a check on the accuracy of this source, the ad valorem rate on crude petroleum reported for the U.S. was examined. It implied a duty of about $9.5 \$ / b b l$. Since this is very close to the actual rate of $10.5 \$ / \mathrm{bbl}$. in existence at that time, a measure of corroboration for the G.A.T.T. data was obtained.

${ }^{13}$ This information was taken from Eurostat (1974). 
${ }^{14}$ of course, a major change in tax policy for crude petroleum producers took place in May 1975, when the depletion allowance was discontinued. However, this tax change related to crude petroleum and other fossil fuels. Although it is possible that this policy influenced refined product production decisions indirectly, particularly in integrated petroleumi firms, we are aware of no estimates of this effect. Thus, it is assumed that the influence of this tax change is entirely captured by changes in crude oil prices.

${ }^{15}$ The U.S. Bureau of Mines, International Petroleum Annual, reports some data on foreign retail prices for gasoline in 1970-71. However, since only one quotation per year is reported, it was decided to use the price series discussed in Section 5.5.2.

${ }^{16}$ Personal communication from Susanne Black, U.S. Central Intelligence Agency.

${ }^{17}$ Sorting out the effects of income and property taxes upon product prices is, of course, a general equilibrium problem of enormous complexity, and one which the public finance profession has yet to solve.

${ }^{18}$ This estimate was obtained by simply comparing the difference in refining margins in the U.S. and the Netherlands to differences in refinery yields of motor gasoline in 1976-77. Linear interpolation was then used to derive a crude estimate of the difference between refining margins in the Netherlands and West Germany. 


\section{REFERENCES}

Adelman, M. A. The World Petroleum Market. Baltimore: Johns Hopkins University Press, 1972.

Chapel, Stephen W. The 0il Entitl ements Program and Its Effects on the Domestic Refining Industry. Santa Monica: Rand Corporation, 1976.

Cox, J. C. and A. W. Wright. "The Effects of Crude 011 Price Controls, Entitlements, and Taxes on Refined Product Prices and Energy Independence," Land Economics, 54 (1978), 1-15.

Ell ison, A. P. Past and Future Energy Costs in the Canadian Economy. Canadian Energy Research Institute, University of Calgary, 1978.

Eurostat. The Evolution of Prices of $0 i 1$ Fuels in the Nine Countries of the European Community from 1960-1974. Brussels: Statistical Office of the European Communities, 1974.

Foster Associates. Energy Prices 1960-73. Cambridge, Mass.: Ballinger Publishing Company, 1974.

Friedman, M. "Two Economic Fallacies," Newsweek, June 23, 1975.

Goldberger, A. Econometric Theory. New York: Wiley and Sons, 1964.

Hall, R. E. and R. S. Pindyck. "The Conflicting Coals of National Energy Policy," The Public Interest, 47 (1977) 3-15.

Imperial 0 il Company, Ltd. Federal Government Price Controls. (Mimeo), 1978.

Johnson, William A. "The Impact of Price Controls on the 0il Industry: How to Worsen an Energy Crisis," in Energy: The Pol icy Issues, edited by Gary D. Eppen. Chicago: University of Chicago Press, 1975.

Kalt, Juseph P. Federal Regulation of Petroleum Prices: Regulatory Wealth Redistribution. Law and Economics Workshop, Department of Economics, U.C.L.A., June 8, 1977.

MacAvoy, Paul W., ed. Federal Energy Administration Regulations. Report of the Presidential Task Force. Washington, D.C.: American Enterprise Institute for Public Policy Research, 1977.

Phelps, C. E. and R. T. Smith. Petroleum Regulation: The False Dilemma of Decontrol. Santa Monica: Rand Corporation, 1977. 
Refiner Price Regulations - Increased Non-product Costs and Allocation of Increased Costs to Exempt Products. Federal Energy Administration Federa. Register, 47, No. 148 (June 30, 1976).

Roush, C. T. Effects of Federal Price and Allocations Regulations on the Petroleum Industri:. U.S. Federal Trade Commission Staff Report, 1976,

U.S. Federal Energy Administration. Findings and Views Concerning the Exemption of Naptha Jet Fuel. Washington, D.C., September 1976.

- Preliminary Findings and Views Concerning the Exemption of Motor Gasoline. Washington, D.C., August 9977.

- Report to Congress on Economic Impact of Energy Actions, February 1975 (distributed through NTIS).

United States Laws and Statutes: Code of Federal Regulations. Executive Orders and Proclamations, \#! s 3279, 4210,4227, 4341, 4355, 4370, 4377 and 4412. Washington, D.C.: Office of Federal Regulations.

Yang, J. "The Nature and Origins of the U.S. Energy Crisis," Federal Reserve Bank of St. Louis Review, 1977, 2-12. 
Eurostat. Hydrocarbons: Monthly Bulletin Special Number-1977.

Brussels: European Communities Statistical Office, 1977.

General Agreement on Tariffs and Trade. Basic Documentation for

Tariff Study. Geneva: G.A.T.T., $197 \overline{0}$.

- Certification of Changes to Schedules of the General

Agreement on Tariffs and Trade. Geneva: G.A.T.T., various years.

H. P. Drewry, Ltd. Shipping Statistics and Economics, (various issues) London.

International Tanker Nominal Freight Scale Association and Association of Ship Brokers and Agents, Inc. Worldwide Tanker Nominal Freight Scale (Worldscale). New York and London, 1970-1978.

0il and Gas Journal. Tulsa, 1968-1977 (various issues).

Organization for Economic Cooperation and Development. 0il StatisticsSupply and Disposal. Brussels, (various issues).

Platt's 0il Price Handbook, 19.. New York: McGraw-Hill, 1968-1977.

U.S. Bureau of Census. Classification of Customs Districts and Ports. Washington, D.C.: U.S. Government Printing Office, 1972.

- U.S. General Imports. Washington; D.C.: U.S. Government Printing Office, (various issues).

U.S. Centra1 Intelligence Agency. International $0 i$ il Developments: Statistical Survey. Washington,. D.C.: U.S. Government Printing office, (various issues).

U.S. Bureau of Mines. International Petroleum Annual, 197. Washington, D.C.: U.S. Government Printing office, (various issues).

U.S. Department of Commerce. U.S. Imports for Consumption and General Imports uf Chemicdls and Related Products. Washington, D.C.: National Technical Information Service, Springfield, Virginia.

U.S. Federa1 Energy Administration. FEO-96 Report: Bank 1. F.E.A.: Office of Data Services.

- Monthly Energy Review. Washington, D.C.: U.S. Government Printing Office, March 1978.

- Petroleum Market Shares: Historical Report on Refiners and and Importers of Motor Gasoline, 1972-1975. Washington, D.C., 1975. 
U.S. Federal Reserve Board. Federal Reserve Bulletin. Washington, D.C.: U.S. Government Printing 0ffice, 1970-1977 (various issues).

U.S. International Trade Commission. Tariff Schedules of the United States Annotated. Washington, D.C., 1978.

United Nations Statistical Office. World Trade Annual, 1972. New York: Walker and Co., 1973.

- Yearbook of International Trade Statistics, 1976. Vol. II: New York, 1977. 
U.S. Department of Energy

Energy Information Administration

Office of Energy Information Services

1726 M St. , N.W.

Washington, D.C. 20461

OFFICIAL BUSINESS

PENALTY FOR PRIVATE USE, $\$ 300$
FIRS IS MAIL

POSTAGE \& FEES PAID

U.S. DEPT. OF ENERGY PERMIT NO. $G 20$

FIRST CLASS MAIL 